Prepared in cooperation with the Nuclear Regulatory Commission

\title{
Improving Flood-Frequency Analysis with a 4,000-Year Record of Flooding on the Tennessee River near Chattanooga, Tennessee
}

Scientific Investigations Report 2020-5138 
Cover. View looking upstream near river mile 445, Tennessee River Gorge of the Tennessee River, Tennessee. Photograph by Tessa Harden, U.S. Geological Survey, March 22, 2016. 


\section{Improving Flood-Frequency Analysis with a 4,000-Year Record of Flooding on the Tennessee River near Chattanooga, Tennessee}

By Tessa M. Harden, Jim E. O'Connor, Meredith L. Carr, and Mackenzie Keith

Prepared in cooperation with the Nuclear Regulatory Commission

Scientific Investigations Report 2020-5138 


\section{U.S. Geological Survey, Reston, Virginia: 2021}

For more information on the USGS - the Federal source for science about the Earth, its natural and living resources, natural hazards, and the environment—visit https://www.usgs.gov or call 1-888-ASK-USGS.

For an overview of USGS information products, including maps, imagery, and publications, visit https://store.usgs.gov/.

Any use of trade, firm, or product names is for descriptive purposes only and does not imply endorsement by the U.S. Government.

Although this information product, for the most part, is in the public domain, it also may contain copyrighted materials as noted in the text. Permission to reproduce copyrighted items must be secured from the copyright owner.

Suggested citation:

Harden, T.M., O'Connor, J.E., Carr, M.L., and Keith, M., 2021, Improving flood-frequency analysis with a 4,000-year record of flooding on the Tennessee River near Chattanooga, Tennessee: U.S. Geological Survey Scientific Investigations Report 2020-5138, 64 p., https://doi.org/10.3133/sir20205138.

Associated data for this publication:

Harden, T.M., 2021, Hydraulic modeling and flood-frequency analyses using paleoflood hydrology for the Tennessee River near Chattanooga, Tennessee: U.S. Geological Survey data release, https://doi.org/10.5066/P914SLVM.

ISSN 2328-0328 (online) 


\section{Acknowledgments}

Thomas Aird of the Nuclear Regulatory Commission contributed to the initial stages of the hydraulic modeling effort. 



\section{Contents}

Acknowledgments ……...................................................................................................................

Abstract

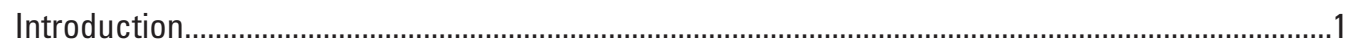

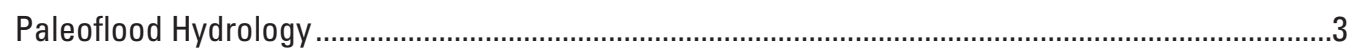

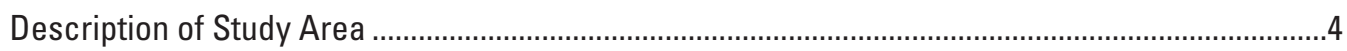

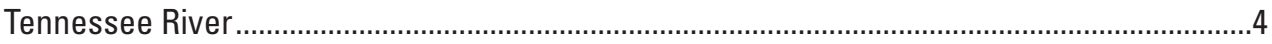

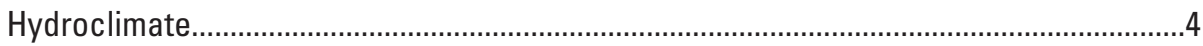

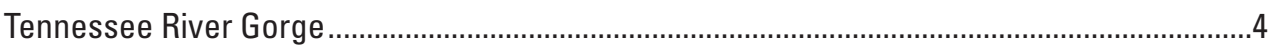

Historical and Modern Streamflow Record ..........................................................................

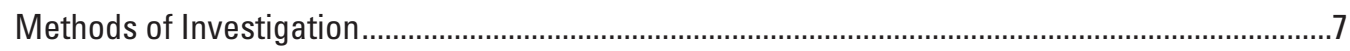

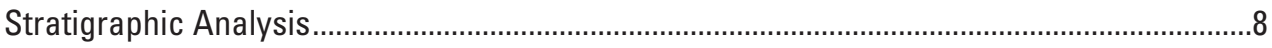

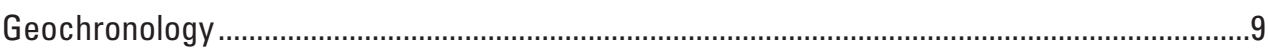

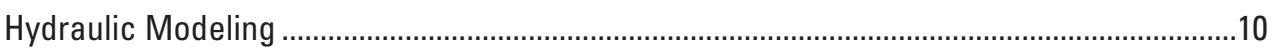

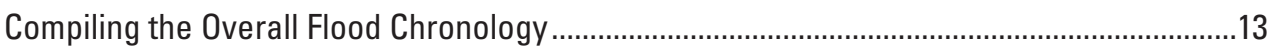

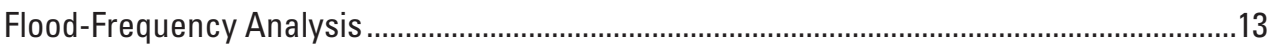

Stratigraphic Analysis and Site Paleoflood Chronologies..........................................................14

Site Descriptions, Stratigraphy, and Geochronology ……….................................................14

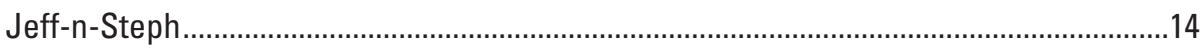

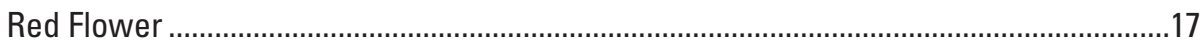

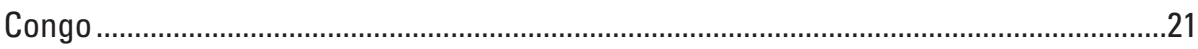

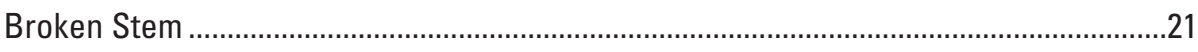

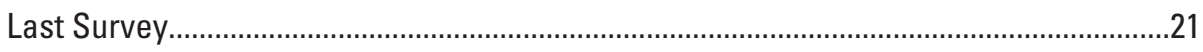

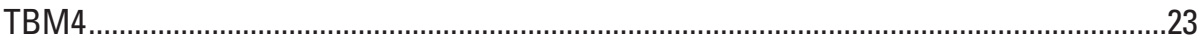

Overall Paleoflood Chronology—Number, Magnitude, and Timing ...............................................28

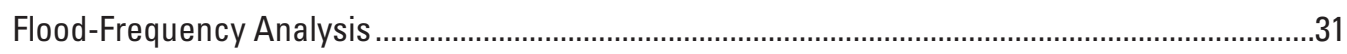

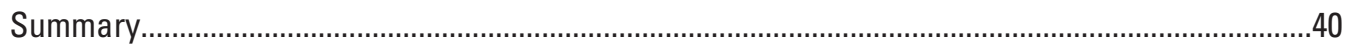

References Cited............................................................................................................. 41

Appendix 1. Stratigraphic Descriptions of Supporting Paleoflood Sites .......................................46

\section{Figures}

1. Map of the Tennessee River Basin showing the study reach and three nuclear power plants along the Tennessee River, southeastern United States.............................3

2. Map showing the study area and paleoflood study sites just downstream from Chattanooga and within the Tennessee River Gorge, Tennessee .....................................5

3. Photograph showing the sandstone cliffs of the Tennessee River Gorge,

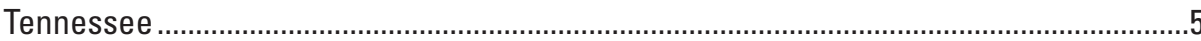

4. Photograph showing large colluvial boulders common to the hillslope in the Tennessee River Gorge, Tennessee ..........................................................................6

5. Photograph showing the Tennessee River Gorge occupied by the now-impounded Tennessee River (Nickajack Lake), Tennessee ......................................6

6. Photograph showing boulder alcoves where sediments providing evidence of paleofloods are deposited and preserved for hundreds to thousands of years, in the Tennessee River Gorge, Tennessee 
7. Photograph showing a laminated flood deposit likely from the 1867 historical flood on the Tennessee River, Tennessee

8. Schematic showing main reach and sub-reaches of the hydraulic model used in this study of the Tennessee River Basin, Tennessee .....

9. Photographs showing large boulder creating the rock overhang that helps to preserve the site and stratigraphy of the pit, at the Jeff-n-Steph site, Tennessee River, Tennessee

10. Diagrams showing location of paleoflood sites in study relative to elevation and surface water profiles from the 1867 historical flood as well as other large floods in the gaged record, Tennessee River Basin, Tennessee

11. Schematic diagram showing the four flood deposits, intervening angular gravel clasts, and deposit of local material at the base of the pit, at the Jeff-n-Steph site, Tennessee River Gorge, Tennessee.

12. Photographs showing location of the pit adjacent to a large sandstone boulder and stratigraphy of the pit that includes one paleoflood deposit between deposits of local material, at the Red Flower site, Tennessee River, Tennessee

13. Schematic diagram showing one flood deposit between deposits of local material, at the Red Flower site, Tennessee River, Tennessee. 20

14. Photographs showing location of the pit and stratigraphy of the pit including evidence of two floods, at the Congo site, Tennessee River, Tennessee.

15. Schematic diagram showing exposed stratigraphy at the Congo site, Tennessee River, Tennessee.

16. Photographs showing location of the pit underneath a boulder overhang and relative to the river and stratigraphy exposed in the pit, at the broken Stem site, Tennessee River, Tennessee.

18. Photographs showing the location of pits $A$ and $B$ along the narrow bedrock ledge as well as the stratigraphy of pit B, at the Last Survey site, Tennessee River, Tennessee

19. Schematic diagram showing the stratigraphy in pits A and B at the Last Survey site, Tennessee River, Tennessee

20. Photographs showing location of the pit and exposed stratigraphy in the pit, at the TBM-4 site, Tennessee River, Tennessee

21. Schematic diagram showing the stratigraphy at the TBM4 site, Tennessee River, Tennessee

22. Diagram showing floods in paleoflood sites, site relative to discharge required to inundate each site, number of flood deposits at each site, and relation of each flood to those at other sites, Tennessee River, Tennessee.

23. Graph showing largest peak annual discharge, arrayed by drainage basin, from more than 22,000 U.S. Geological Survey streamgages in the United States and Puerto Rico

24. Graph showing gaged and historical data included in the gaged plus historical flood-frequency analysis (scenario 1) of the Tennessee River, Tennessee.

25. Graphs showing gaged, historical, and paleoflood data and associated perception thresholds included in scenarios 2-7, Tennessee River, Tennessee

26. Graph showing flood-frequency analysis including all gaged and historical flood data (scenario 1), Tennessee River, Tennessee

27. Graph showing flood-frequency analysis including all gaged data, the 1867 historical flood and four paleofloods (scenario 3), Tennessee River, Tennessee. 
28. Graphs showing selected flood-frequency analysis curves including all gaged data, the 1867 historical flood, and four paleofloods (scenarios 1, 3, and 5-7), Tennessee River, Tennessee.

29. Graph showing estimated discharges and 95-percent confidence limits of the flood-frequency analyses for the seven flood scenarios for the 0.001 annual exceedance probability, Tennessee River, Tennessee.

\section{Tables}

1. Largest documented floods for U.S. Geological Survey streamgage 03568000, Tennessee River at Chattanooga, Tennessee.

2. Radiocarbon dating results from paleoflood study sites in the Tennessee River Gorge near Chattanooga, Tennessee..

3. Optically simulated luminescence dating results from paleoflood study sites near Chattanooga, Tennessee

4. Eight individual paleofloods, the sites where the paleoflood deposits were found, the plausible dates on which they occurred, and associated discharge estimates for each flood, Tennessee River, Tennessee

5. Five perception thresholds used in the flood-frequency analyses, Tennessee

River, Tennessee

6. Seven flood scenarios, including date of flood; sites where evidence was preserved; and estimated discharge median, minimum, and maximum, used in the flood-frequency analyses, Tennessee River, Tennessee ..

7. Flood-frequency results of five flood quantiles (0.01-0.0001 annual exceedance probability) for scenarios 1-7, Tennessee River, Tennessee

\section{Conversion Factors}

U.S. customary units to International System of Units

\begin{tabular}{lll}
\hline \multicolumn{1}{c}{ Multiply } & \multicolumn{1}{c}{ By } & \multicolumn{1}{c}{ To obtain } \\
\hline inch (in.) & \multicolumn{2}{c}{ Length } \\
foot (ft) & 2.54 & centimeter $(\mathrm{cm})$ \\
mile (mi) & 0.3048 & meter $(\mathrm{m})$ \\
\hline \multicolumn{3}{c}{ Area } \\
\hline square foot $\left(\mathrm{ft}^{2}\right)$ & 1.609 & kilometer $(\mathrm{km})$ \\
square mile $\left(\mathrm{mi}^{2}\right)$ & 0.09290 & square meter $\left(\mathrm{m}^{2}\right)$ \\
\hline & 2.590 & square kilometer $\left(\mathrm{km}^{2}\right)$ \\
\hline cubic foot per second $\left(\mathrm{ft}^{3} / \mathrm{s}\right)$ & Flow rate & \\
\hline
\end{tabular}

International System of Units to U.S. customary units

\begin{tabular}{lcll}
\hline & Multiply & By & To obtain \\
\hline & Length & & \\
\hline millimeter $(\mathrm{mm})$ & 0.03937 & inch (in.) & \\
centimeter $(\mathrm{cm})$ & 0.3937 & inch (in.) &
\end{tabular}




\begin{tabular}{|c|c|c|}
\hline Multiply & By & To obtain \\
\hline meter (m) & 3.281 & foot $(\mathrm{ft})$ \\
\hline kilometer (km) & 0.6214 & mile (mi) \\
\hline \multicolumn{3}{|c|}{ Area } \\
\hline square meter $\left(\mathrm{m}^{2}\right)$ & 10.76 & square foot $\left(\mathrm{ft}^{2}\right)$ \\
\hline square kilometer $\left(\mathrm{km}^{2}\right)$ & 0.3861 & square mile $\left(\mathrm{mi}^{2}\right)$ \\
\hline \multicolumn{3}{|c|}{ Flow rate } \\
\hline cubic meter per second $\left(\mathrm{m}^{3} / \mathrm{s}\right)$ & 35.31 & cubic foot per second $\left(\mathrm{ft}^{3} / \mathrm{s}\right)$ \\
\hline \multicolumn{3}{|c|}{ Mass } \\
\hline $\operatorname{gram}(\mathrm{g})$ & 0.03527 & ounce, avoirdupois (oz) \\
\hline
\end{tabular}

\section{Datums}

Vertical coordinate information is referenced to the North American Vertical Datum of 1988 (NAVD 88) unless otherwise stated.

Horizontal coordinate information is referenced to the North American Datum of 1927 (NAD 27)

Elevation, as used in this report, refers to distance above the vertical datum.

\section{Abbreviations}

$\begin{array}{ll}\text { AEP } & \text { annual exceedance probability } \\ \text { bls } & \text { below land surface } \\ \text { BP } & \text { before present } \\ { }^{14} \mathrm{C} & \text { carbon-14 } \\ { }^{12} \mathrm{C} & \text { carbon-12 } \\ \mathrm{Cl} & \text { confidence interval } \\ \mathrm{D}_{\mathrm{e}} & \text { equivalent dose } \\ \text { HEC-RAS } & \text { Hydrologic Engineering Center-River Analysis System } \\ \text { 1D } & \text { one-dimensional } \\ \text { NRC } & \text { Nuclear Regulatory Commission } \\ \text { OSL } & \text { optically stimulated luminescence } \\ \text { RM } & \text { river mile(s) } \\ \text { TCFCP } & \text { The Chattanooga Flood Control Problem } \\ \text { TVA } & \text { Tennessee Valley Authority } \\ \text { USACE } & \text { U.S. Army Corps of Engineers } \\ \text { USGS } & \text { U.S. Geological Survey }\end{array}$




\title{
Improving Flood-Frequency Analysis with a 4,000-Year Record of Flooding on the Tennessee River near Chattanooga, Tennessee
}

\author{
By Tessa M. Harden, ${ }^{1}$ Jim E. O'Connor, ${ }^{1}$ Meredith L. Carr, ${ }^{2}$ and Mackenzie Keith ${ }^{1}$
}

\section{Abstract}

This comprehensive field study applied paleoflood hydrology methods to estimate the frequency of lowprobability floods for the Tennessee River near Chattanooga, Tennessee. The study combined stratigraphic records of large, previously unrecorded floods with modern streamflow records and historical flood accounts. The overall approach was to (1) develop a flood chronology for the Tennessee River near Chattanooga using stratigraphic analyses and geochronology from multiple sites at multiple elevations in the study area; (2) estimate peak flow magnitudes associated with elevations of flood evidence using a one-dimensional hydraulic model; (3) combine the information obtained from steps 1 and 2 to develop a history of timing and magnitude of large floods in the study reach; and (4) use all available information (including paleoflood, gaged, and historical records of flooding) to estimate flood frequency using a standardized statistical approach for flood-frequency analysis.

The stratigraphy, geochronology, and hydraulic modeling results from all paleoflood sites along the Tennessee River were distilled into an overall chronology of the number, timing, and magnitude of large unrecorded floods. In total, 30 sites were identified and the stratigraphy of 17 of those sites was closely examined, measured, and recorded. Floodfrequency analyses were done using the U.S. Geological Survey software program PeakFQ v7.2 that follows the Guidelines for Determining Flood Flow FrequencyBulletin 17C.

Resolving stratigraphic and chronologic information from all 17 sites yielded information for eight unique large floods in the last 3,500-4,000 years for the Tennessee River near Chattanooga. Two of these floods had discharges of 470,000 cubic feet per second $\left(\mathrm{ft}^{3} / \mathrm{s}\right)$, slightly greater than the 1867 historical peak at the Chattanooga streamgage $\left(459,000 \mathrm{ft}^{3} / \mathrm{s}\right)$. One flood with a discharge of $1,100,000 \mathrm{ft}^{3} / \mathrm{s}$ was substantially greater than any other flood on the Tennessee River during the last several thousand years. This large flood occurred only a few hundred years ago, likely in the mid-to-late 1600s. Two

\footnotetext{
${ }^{1}$ U.S. Geological Survey

${ }^{2}$ Nuclear Regulatory Commission
}

additional floods in the last 1,000 years had estimated magnitudes of about 420,000 and $400,000 \mathrm{ft}^{3} / \mathrm{s}$. The remaining three unique floods identified in the paleoflood record were much smaller (less than $240,000 \mathrm{ft}^{3} / \mathrm{s}$ ) and occurred about 3,000-800 years ago.

Flood-frequency analyses show that the addition of paleoflood information markedly improves estimates of low probability floods - most clearly shown by substantial narrowing of the 95-percent confidence limits. For the most plausible flood scenario, the 95-percent confidence interval for the 1,000-year quantile estimate derived from incorporating the four most recent paleofloods is about 480,000-620,000 $\mathrm{ft}^{3} / \mathrm{s}$ compared to about $380,000-610,000 \mathrm{ft}^{3} / \mathrm{s}$ for the gaged and historical record alone, a reduction in the uncertainty of the estimate by 38 percent. Similarly, uncertainty for all flood quantile estimates from 100 to 10,000 years was reduced by $22-44$ percent by the addition of the paleoflood record to the flood-frequency analyses.

\section{Introduction}

Nuclear powerplants in the United States commonly are located near large rivers or coastlines because of cooling-water requirements. This proximity to large water bodies increases the risk of plant flooding. In summer 2011, heavy flooding along the Missouri River was a cause for concern at several large Omaha Public Power District stations including the Fort Calhoun nuclear power plant located north of Omaha, Nebraska. Heavy spring rains combined with a rapidly melting above-average snowpack in the Missouri Basin created severe flooding that threatened to inundate that nuclear power plant. Although the plant had been shut down for refueling prior to the flooding and the water-surface elevation peaked 6 feet below the reactors, the 2011 flooding posed an unprecedented risk to a U.S. nuclear power facility. Less than 3 months before the Missouri River flooding, a tsunami following an earthquake inundated a nuclear power plant in Fukushima Dai' ichi, Japan, resulting in the eventual release of radioactive material (Kurokawa and others, 2012; World Nuclear Association, 2018). These events prompted government 
agencies to emphasize better risk-based assessment of inundation hazards for nuclear power plants, including reducing uncertainty in flood-frequency analyses (National Resource Council, 2014).

Most conventional flood-frequency analyses use statistical techniques applied to streamgage data. Such analyses typically are limited to records of less than 100 years in the United States. Oftentimes, the short-term streamgage records either do not record low-probability floods or they record a rare event that seems to be out of historical context in the relatively short streamgage record. This, in turn, can lead to significant uncertainty in flood-frequency analyses (Harden and others, 2011). Therefore, much research has aimed to improve estimates of the frequency and magnitude of large flood events with low annual exceedance probabilities (AEP), here considered to be AEP values of 0.005 or less (Benito and others, 2004; Jarrett and Tomlinson, 2000; Lam and others, 2017). One method of improving flood recurrence estimates, especially for floods with AEPs less than 0.05 (Stedinger and Cohn, 1986; Hosking and Wallis, 1986; Frances and others, 1994; Kohn and others, 2016), is through paleoflood hydrology (Baker and others, 1979; Harden and others, 2011; Benito and O'Connor, 2013; Greenbaum and others, 2014) in which geologic evidence is used to develop quantitative records of large floods that have occurred in the past (Baker, 1987).

Because of recent flooding near nuclear facilities, a desktop screening study addressing inundation hazards to nuclear power plants through the use of geologically extended histories of riverine floods, tsunamis, and storm surges was conducted by the U.S. Geological Survey (USGS) in cooperation with the Nuclear Regulatory Commission (NRC) during 2013-14 (O'Connor and others, 2014). The screening study used available hydrologic, geographic, and geologic information. It accounted for the proximity of nuclear powerplants to rivers and the geologic and physiographic conditions of the watershed and river corridor relevant to forming and preserving paleoflood deposits. That study identified several rivers in the southeastern United States with high potential for improving flood-frequency estimates through paleoflood investigations. The Tennessee River in particular was determined to be a good candidate for analysis because of its sedimentproducing geology, reaches with stable boundaries, and the presence of three nuclear power plants-Watts Bar, Sequoyah, and Browns Ferry (fig. 1) - operated by the Tennessee Valley Authority (TVA).

In 2016, the USGS, in cooperation with the NRC, conducted a feasibility study (Harden and O'Connor, 2017) on the Tennessee River to determine if conventional paleoflood investigation techniques might be successful for improving estimates of flood recurrence. A key question was whether such an approach could work in humid regions of the United States and whether flood-frequency estimates could be improved and used for flood-risk evaluations for nuclear power plants. The humid-region site of the Tennessee River contrasts with most previous paleoflood work in the United States, which has been done in arid or semi-arid regions. Key questions addressed were as follows:

1. What specific settings provide long-duration records of flood sediment?

2. Does increased bioturbation from plants and animals in humid regions hinder identification of individual flood units?

3. Do standard approaches for dating flood deposits, such as radiocarbon and optically stimulated luminescence, work well in active soil-forming environments such as the southeastern United States?

Results of the Harden and O'Connor (2017) study indicated that the Tennessee River Gorge was an excellent location for a comprehensive paleoflood study. Caves, alcoves, bedrock ledges, and large colluvial boulders found at multiple elevations provide suitable environments for flood sediment accumulation and preservation. Although deposits were extensively bioturbated by plants, insects, and animals, identification of distinct flood deposits at many sites was made possible by careful stratigraphic examination. Harden and O'Connor (2017) also showed that standard approaches for dating flood deposits, such as radiocarbon and optically stimulated luminescence, were suitable for the active soilforming environment of the southeastern United States. This preliminary work indicated that at least a 3,000-year record of flooding has been recorded by slackwater flood deposits along the Tennessee River. 


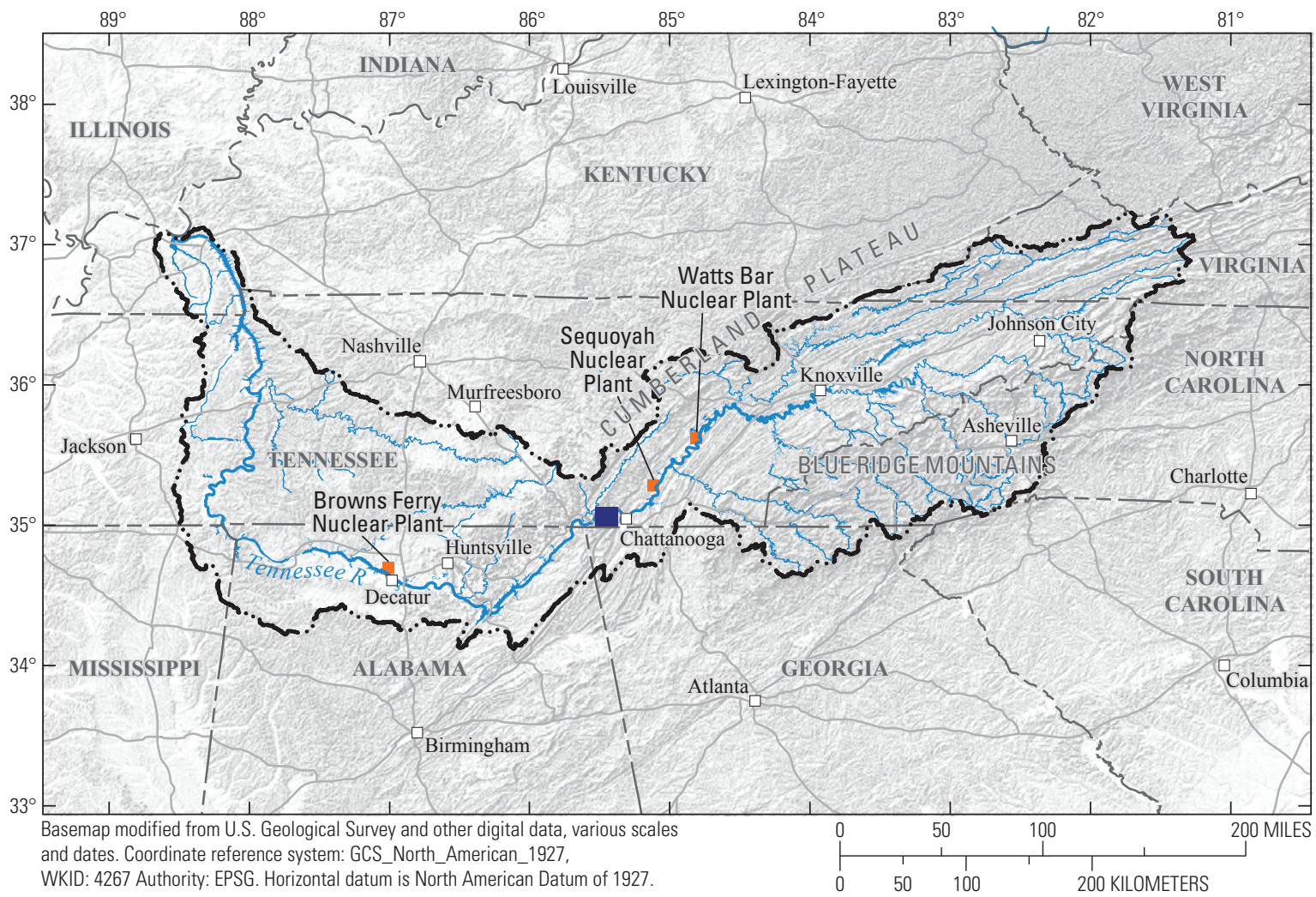

EXPLANATION

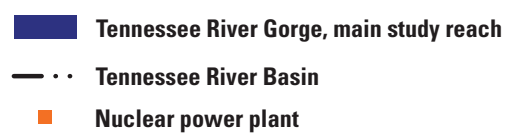

Figure 1. Tennessee River Basin showing the study reach and three nuclear power plants along the Tennessee River, southeastern United States.

\section{Paleoflood Hydrology}

An established approach for reducing uncertainty related to flood hazards is to incorporate data from large, previously unrecorded floods, or paleofloods, in the flood-frequency analysis (Baker and others, 1979; Salas and others, 1994; O'Connor and others, 1994; Hosman and others, 2003; Harden and others, 2011; Benito and O'Connor, 2013; Greenbaum and others, 2014). Paleoflood hydrology uses geological and botanical evidence to quantitatively estimate the magnitude and timing of large floods occurring prior to observational records. In certain environments, these records may span thousands of years, adding critical information to the gaged record and, when combined with the gaged and historical records, substantially reduce uncertainty in flood-frequency estimates (Hosman and others, 2003; Harden and others, 2011; O'Connor and others, 2014).

As a science, paleoflood hydrology has been recognized in the United States since the 1800s (Costa, 1978; Patton, 1987; Baker, 2008). Although some of the early works contain speculative conclusions, the science has evolved tremendously through the early and mid-1900s, led by J Harlen Bretz (Bretz, 1923, 1928, 1929), J.E. Stewart (Stewart and Bodhaine, 1961) and R.H. Jahns (Jahns, 1947). Starting in the mid-to-late 1970s and building on early analyses by Costa (1978) and Baker and others (1979), paleoflood studies in the United States increased significantly, spearheaded by Vic Baker (University of Arizona) and many of his students (Patton and others, 1979; Ely and Baker, 1985; Patton, 1987; Baker and others, 1988; Kochel and Baker, 1988; Webb and others, 1988; Baker, 1989; O'Connor and others, 1994). These studies mainly relied on stratigraphic records of fine-grained flood deposits preserved in low-energy depositional environments, such as caves, alcoves, tributary mouths, and overbank areas. These earlier studies focused on the reconstruction of individual floods, mainly in semi-arid and arid environments, providing invaluable information for the understanding of large floods. Later, during the 1990s, statistical techniques started to be developed to use paleoflood data in quantitative floodfrequency analyses (Stedinger and Cohn, 1986; Stedinger and Baker, 1987; Levish, 2002; O'Connell and others, 2002). Paleoflood hydrology is now applied globally (for example, 
Herget and Fontana, 2020), and current methods for assessing flood frequency are specifically designed to incorporate the results from such studies, such as analyses using methods outlined in Bulletin 17C, the Federal guidelines for floodfrequency analysis (England and others, 2018).

\section{Description of Study Area}

\section{Tennessee River}

The Tennessee River forms in Knoxville, Tennessee, at the confluence of the Holston and French Broad Rivers and flows for 652 river miles ${ }^{3}$ (RM) through Tennessee, northern Alabama, northeastern Mississippi, and western Kentucky, and into the Ohio River near Paducah, Kentucky, near its confluence with the Mississippi River. The river basin encompasses about $41,000 \mathrm{mi}^{2}$ (fig. 1). It is the seventh largest river in the United States in terms of mean annual discharge (Kammerer, 1990). Since the creation of the Tennessee Valley Authority in 1933, multiple dams and other infrastructure have altered the hydrogeomorphic character of the Tennessee River by trapping sediment behind large dams, creating large storage reservoirs and altering the natural flood regime (Marren and others, 2014). Prior to the dams, the Tennessee River was difficult to navigate beyond the lower reaches because of swift currents, shallow water, rapids, and rocky shoals.

The Tennessee River Basin spans multiple physiographic provinces. In the southeastern basin, multiple tributaries such as the French Broad River head in the Blue Ridge physiographic province primarily are underlain by Precambrian metamorphic rocks. Rivers such as the Holston River drain the Valley and Ridge physiographic province, which is dominantly formed of Cambrian to Ordovician sedimentary rocks deformed into a series of synclines and anticlines in the Tennessee section.

\section{Hydroclimate}

The Tennessee River Basin has a humid sub-tropical climate with mean annual rainfall of $51 \mathrm{in} / \mathrm{yr}$, ranging from 38 in/yr $(97 \mathrm{~cm} / \mathrm{yr})$ to $65 \mathrm{in} / \mathrm{yr}(165 \mathrm{~cm} / \mathrm{yr})$ since the late $1800 \mathrm{~s}$. Most precipitation is in the mountainous areas of the headwaters where it is typically $80-90 \mathrm{in} / \mathrm{yr}(200-230 \mathrm{~cm} / \mathrm{yr})$. The principal source of precipitation in the area is warm, northeastmoving, moist air masses derived from the Gulf of Mexico region. However, high-intensity atmospheric disturbances off the Atlantic coast sometimes spill over the Blue Ridge barrier into the Tennessee and Cumberland River Basins (Speer and Gamble, 1964).

\footnotetext{
${ }^{3}$ This report uses river miles for the Tennessee River as reported on USGS topographic maps. In accordance with existing records and standard engineering practice, hydrologic (streamflow, precipitation) and hydraulic model descriptions are expressed in English (U.S. customary) units, as are river miles of the Tennessee River. The stratigraphic analyses and descriptions relating to the paleoflood sites are expressed in metric units.
}

Mean annual runoff of the Tennessee River is about 43 percent of the mean annual precipitation over the drainage area (1890-1990; Tennessee Valley Authority, 1993). Snowfall occurs at the higher elevations, but persistent accumulations of significant depth are rare. Considerable natural storage is afforded by the deep soils and extensive groundwater storage in many of the tributary areas that attenuate runoff. Thick vegetation on steep slopes also helps decrease runoff from heavy precipitation (Tennessee Valley Authority, 1961). Extra-tropical cyclones moving northward into the basin from the Gulf of Mexico during December through April are the major flood-producing storms in the basin. When these storms stagnate, great precipitation volumes overwhelm the natural (and artificial) storage and can cause major widespread flooding. An exceptional instance was the 1867 historical flood at Chattanooga described in more detail in section, "Historical and Modern Streamflow Record," and well documented in conjunction with several other major Tennessee River floods and flood-producing storms in a report by the Tennessee Valley Authority (1961).

\section{Tennessee River Gorge}

The main study reach is located from about RM 443 to 457, within the Tennessee River Gorge just downstream from Chattanooga, Tennessee (fig. 2). The Tennessee River Gorge lies just downstream from the transition from the Tennessee section of the Valley and Ridge physiographic province to the Cumberland Plateau section of the Appalachian Plateau. Here, the Tennessee River has incised through Pennsylvanian and Mississippian carbonate and clastic sedimentary rocks of the uplifted Cumberland Plateau. Sandstone and conglomerate form massive, nearly vertical cliffs hundreds of meters high (fig. 3). Colluvial slopes below the cliffs have local outcrops of limestones, dolomites, and shales, but most commonly are formed of weathered and vegetated colluvium derived from the sandstone cliffs. Of particular relevance to this study are the abundant large colluvial sandstone boulders flanking the gorge throughout its length, which create sheltered areas that preserve historical and prehistoric flood deposits (fig. 4).

During the last 100 years, the Tennessee River within the gorge has been affected by impoundment, first behind Hales Bar Dam (RM 431) and then behind Nickajack Dam (RM 424). Completed in 1913 to improve navigation through the Tennessee River Gorge, the Hales Bar Dam leaked almost immediately because of issues related to its construction on fractured and crevassed limestone (Smithsonian Institution, 2020). Backwater from Hales Bar Dam extended nearly to Chattanooga at about RM 460. Nickajack Dam, completed in 1967, was built to replace Hales Bar Dam, which was dismantled in 1968. The reservoir behind Nickajack Dam reaches all the way to Chickamauga Dam at RM 471, about 10 miles upstream from Chattanooga. 


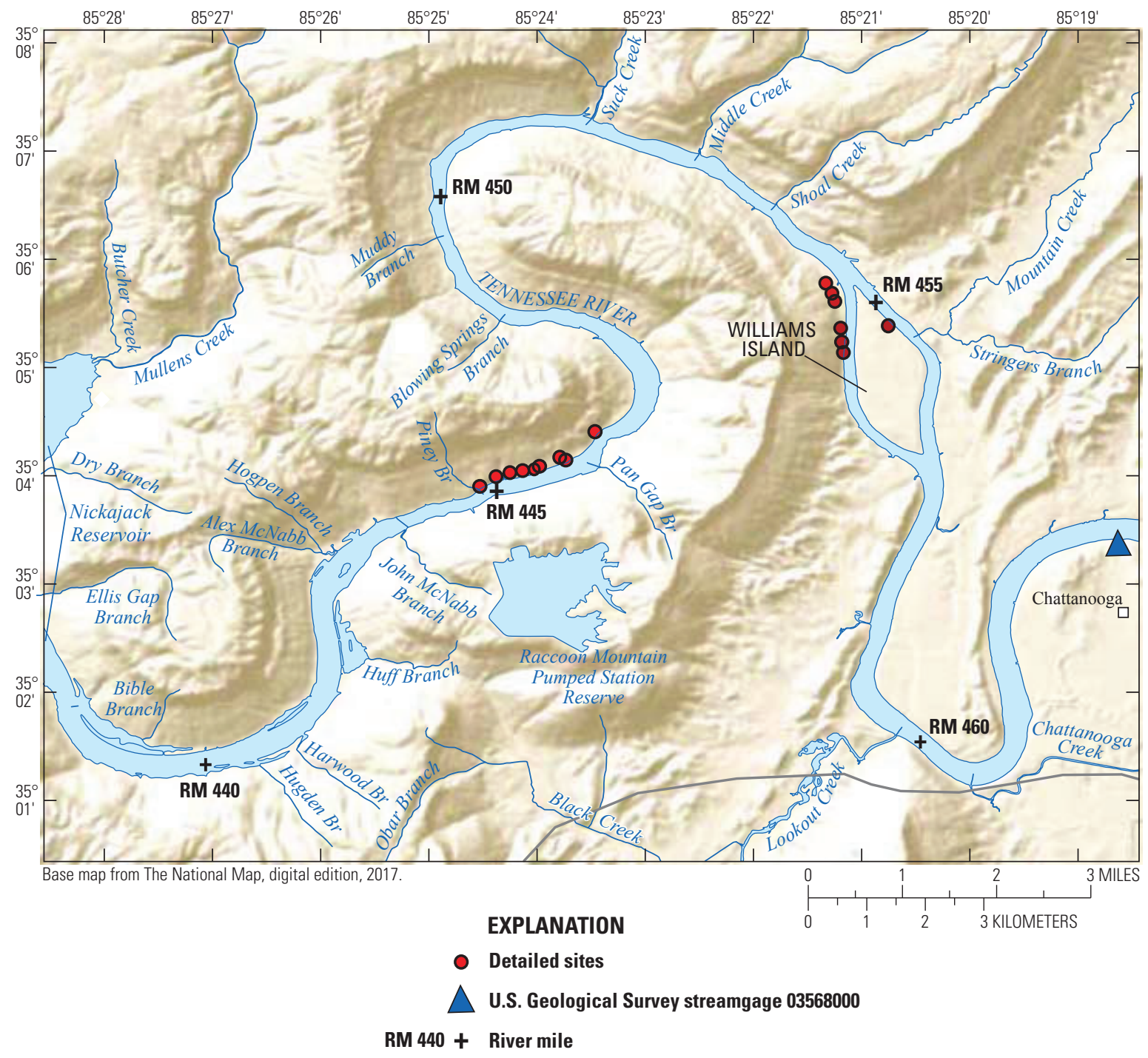

Figure 2. Study area and paleoflood study sites just downstream from Chattanooga and within the Tennessee River Gorge, Tennessee. Streamflow is from right to left.

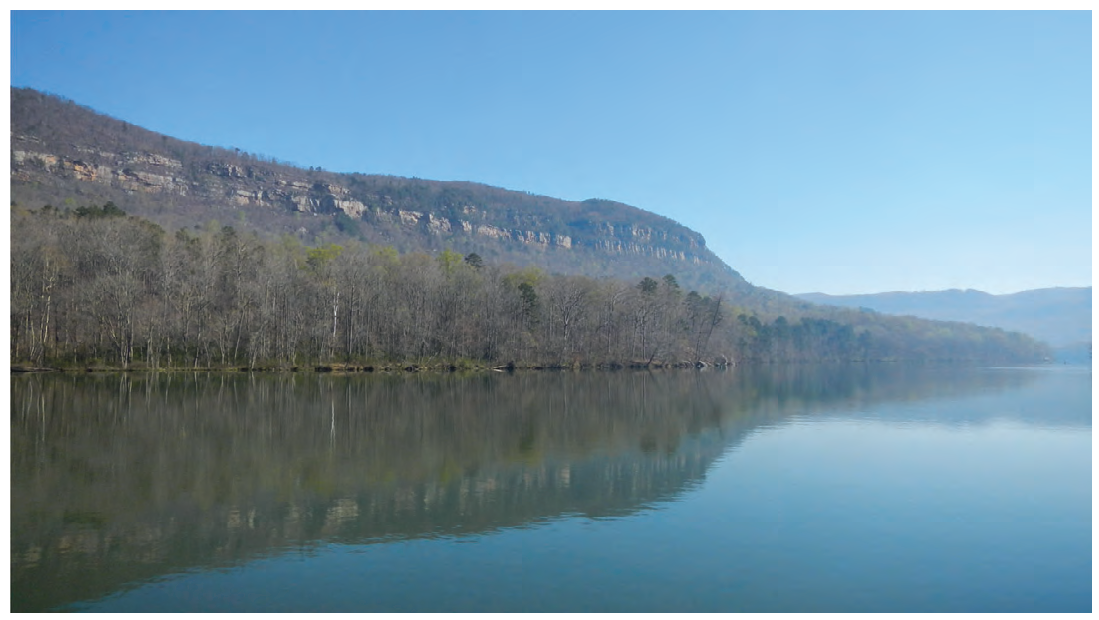

Figure 3. Sandstone cliffs of the Tennessee River Gorge, Tennessee. Photograph was taken looking upstream near river mile 445. 


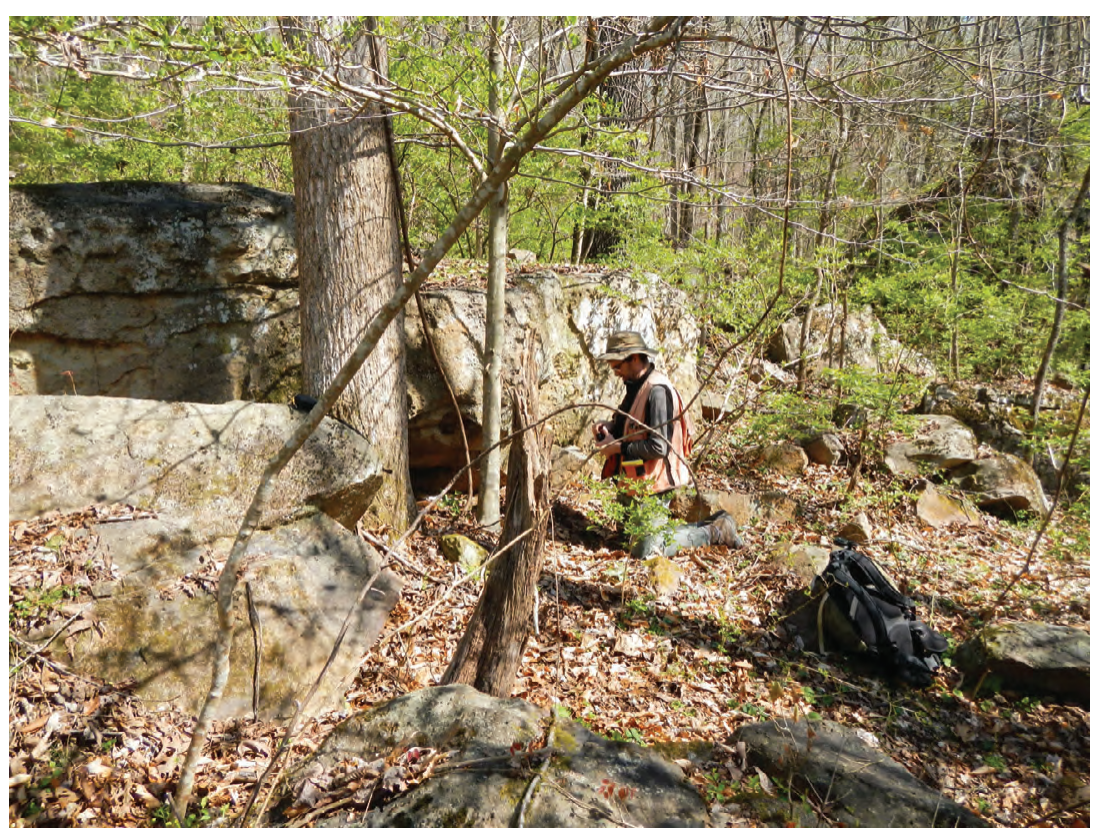

Figure 4. Large colluvial boulders common to the hillslope in the Tennessee River Gorge, Tennessee. These boulders can create sheltered areas ideal for preservation of paleoflood deposits.

Prior to impoundment, the low-flow channel descended a series of bedrock shoals and drops within the study area. Colorful names by early settlers-The Suck, Deadman Eddy, and The Pot - hint at navigation challenges and consequences there. Most of these hazards owe to complicated hydraulics created by large rockfall boulders and bedrock narrows common in the river bottom. The present-day valley bottom within the study area generally is less than about $500 \mathrm{~m}$ wide (fig. 5).

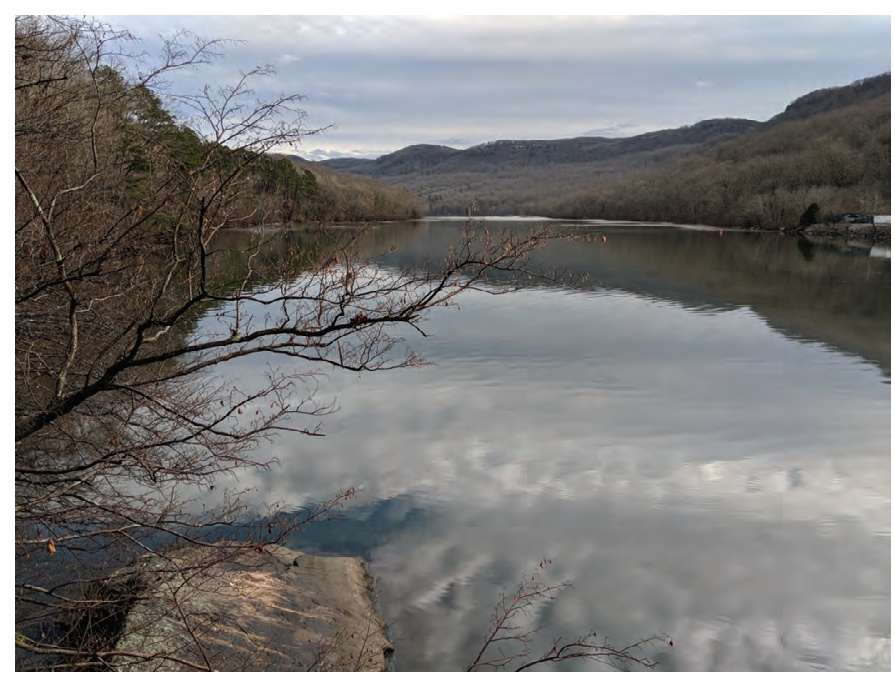

Figure 5. Tennessee River Gorge occupied by the now-impounded Tennessee River (Nickajack Lake), Tennessee. The channel and valley bottom in the gorge generally are less than about 500 meters (1,500 feet) wide. Photograph was taken looking upstream near river mile 445.

\section{Historical and Modern Streamflow Record}

Floods have occurred in all months within the basin, but most large floods on the main-stem Tennessee River result from winter and early spring precipitation (Speer and Gamble, 1964). The TVA and USGS have documented several large floods on the Tennessee River since the early 1800s (table 1; Tennessee Valley Authority, 1939, 1940, 1961; Speer and Gamble, 1964). The largest historical flood and the current peak of record occurred in March 1867. Reliable rainfall records are unavailable for that flood, but the cause was widespread heavy rain from a quasi-stationary frontal-type storm that lasted several days in combination with a melting

Table 1. Largest documented floods for U.S. Geological Survey streamgage 03568000 , Tennessee River at Chattanooga, Tennessee (U.S. Geological Survey, 2019a).

[Symbol: - , no data]

\begin{tabular}{clcc}
\hline $\begin{array}{c}\text { Water } \\
\text { year }\end{array}$ & \multicolumn{1}{c}{ Date } & $\begin{array}{c}\text { Streamgage } \\
\text { height } \\
\text { (feet) }\end{array}$ & $\begin{array}{c}\text { Streamflow } \\
\text { (cubic feet } \\
\text { per second) }\end{array}$ \\
\hline 1826 & March 1826 & 41.5 & - \\
1847 & March 1847 & 42.4 & - \\
1867 & March 11, 1867 & 57.9 & 459,000 \\
1875 & March 1, 1875 & 54.0 & 410,000 \\
1886 & April 3, 1886 & 52.5 & 391,000 \\
1917 & March 7, 1917 & 47.7 & 341,000 \\
\hline
\end{tabular}


snowpack at higher elevations. According to an unnamed newspaper quoted in The Chattanooga Flood Control Problem (TCFCP; Tennessee Valley Authority, 1939):

"The rain which caused this great inundation extended simultaneously from the Blue Mountains composing the entire drainage of the upper Tennessee which, with the melting snow, filled every tributary of that river at nearly the same time."

Near Chattanooga, the resulting flood was described in the Report of Chief of Engineers, 1875-76 and quoted in TCFCP (Tennessee Valley Authority, 1939, p. 71) as follows:

"At Chattanooga, the rise began on March 4, overflowed the banks on March 8, and attained height on March 11, being 53 feet above low water... Rains were incessant for four days before the highest water.... The destruction of property and life occasioned by this flood was beyond parallel in the history of the Tennessee valley."

The flood was especially devastating to Chattanooga because of its unique geography. The city of Chattanooga lies immediately upstream from the mouth of the Tennessee River Gorge. The narrow gorge constricts large flows on the Tennessee River, creating backwater that can flood the city. The valley morphology acts much like an hourglass; the rivers and other waterways draining a contributing area of about 21,000 $\mathrm{mi}^{2}$ upstream from Chattanooga must funnel through the narrow gorge after which it spreads out again into wider flatlands. The discharge estimate for the 1867 flood at Chattanooga is $459,000 \mathrm{ft}^{3} / \mathrm{s}$ for the associated stage of 57.9 $\mathrm{ft}(679.0 \mathrm{ft}$ above North American Vertical Datum of 1988 [NAVD 88]; U.S. Geological Survey, 2019a).

The USGS streamgage 03568000, Tennessee River at Chattanooga, Tennessee, at RM 464.3, has provided a continuous record of annual peak discharge estimates and stage heights since 1874. Based on historical documents and local site information, this record also includes the stage height and a discharge estimate for the historical 1867 flood as well as stage heights for large historical floods in 1826 and 1847 (table 1). For reference, the drainage area of the Chattanooga streamgage is $21,400 \mathrm{mi}^{2}$, compared to about $21,700 \mathrm{mi}^{2}$ for most of the paleoflood sites in this study.

The 1867 flood was not the only large, destructive historical flood on the Tennessee River. On March 1, 1875, prolonged precipitation caused widespread flooding, this time peaking at a stage of $54.0 \mathrm{ft}(675.1 \mathrm{ft}$ above NAVD 88) with an estimated discharge of $410,000 \mathrm{ft}^{3} / \mathrm{s}$ at Chattanooga. Eleven years after the 1875 flood, another large storm caused severe flooding on April 3, 1886. The stage was $52.5 \mathrm{ft}$ (673.6 $\mathrm{ft}$ above NAVD 88) at Chattanooga with an associated peak discharge of $391,000 \mathrm{ft}^{3} / \mathrm{s}$. Since records were kept, only one other flood on the Tennessee River peaked with a discharge of greater than $300,000 \mathrm{ft}^{3} / \mathrm{s}$ at Chattanooga $\left(341,000 \mathrm{ft}^{3} / \mathrm{s}\right.$ in
1917); the rest of the 137 years of annual peaks are at less than $300,000 \mathrm{ft}^{3} / \mathrm{s}$. Although the USGS streamgage at Chattanooga reports only the stages for the large historical floods in 1826 and 1847 , their discharges likely were similar to the March 2, 1890, flood of 283,000 $\mathrm{ft}^{3} / \mathrm{s}$, which was of similar stage. Incorporation of the 1826 and 1847 flood stages in the gaged record indicates that they were the largest floods on the Tennessee River in the 1826-67 period, since larger floods would almost certainly have been reported.

From 1933 to 1979, the TVA constructed 3 dams on the main-stem Tennessee River upstream from the gorge ( 9 total main-stem dams) and 49 dams total in the Tennessee River Basin. These dams provide for power generation, navigation, and flood control; however, the threat from flooding persists. In March 1973, widespread Tennessee Valley flooding resulted in the river stage at Chattanooga cresting at about 36.9 feet (Edelen and Miller, 1976), about 7 feet above flood stage despite upstream reservoirs storing much of the floodwater. Had the reservoirs not been in place, the natural stage height would have peaked at about 52.4 feet (Tennessee Valley Authority, 1974; Edelen and Miller, 1976), a stage similar to that reached by the 1886 flood.

\section{Methods of Investigation}

Stratigraphic records were used to document the age and magnitude of large, previously unrecorded floods. These data were combined with modern streamflow records and historical flood accounts to improve estimates of flood frequency, particularly for floods of low annual exceedance probability. The overall approach was similar to that described in detail in Harden and others (2011) for a paleoflood study conducted in the Black Hills of South Dakota:

1. Develop a flood chronology for the Tennessee River near Chattanooga using stratigraphic analyses and geochronology from multiple sites at multiple elevations in the study area;

2. Estimate peak flow magnitudes associated with elevations of flood evidence using a one-dimensional (1D) hydraulic model;

3. Combine the information developed from steps 1 and 2 to develop a history of timing and magnitude of large floods affecting the study reach; and

4. Use all available information, including paleoflood, gaged, and historical records to calculate floodfrequency analyses using methods outlined in Bulletin $17 \mathrm{C}$, the Federal guidelines for determining flood frequency (England and others, 2018). 


\section{Stratigraphic Analysis}

Once permits and land access were granted, potential paleoflood sites were located by examining both sides of the Tennessee River Gorge on foot and by boat. Within the gorge, most preserved flood deposits suitable for stratigraphic analysis were found beneath large colluvial sandstone boulders along the hillslopes, in caves, underneath bedrock ledges, and in alcoves formed in and along a limestone outcrop on the left bank near the upstream entrance to the gorge. A common situation was that of preserved flood deposits sheltered by large rockfall blocks embedded in the valley slopes. Many of these blocks were large enough to protect the sediment that accumulated at their bases from precipitation and excessive vegetation growth (fig. 6). Searches for appropriate sites were guided by knowledge of the peak water-surface elevations of previous large floods, such as the 1867 and 1917 floods, as described in an extensive Tennessee Valley Authority (1940) flood report. Hand-level surveys provided estimates of approximate site elevations. Knowing approximate site elevations guided site selection to ensure that stratigraphic assessments spanned the entire range of plausible Holocene flood inundation elevations, an important consideration because it is the records of large and rare floods that most influence resulting frequency assessments. Potential sites at multiple elevations were examined to more accurately define the frequency of flooding at different stages and to define an upper limit of flood magnitude during the mid-to-late Holocene $(<4,000-5,000$ years ago).

Once ideal locations were identified, pits as deep as 1 $\mathrm{m}$ were hand dug to expose the stratigraphy. Most pits had a mix of fluvial deposits and deposits of slope wash or other local material. Flood deposits were texturally and mineralogically distinct and commonly were finely laminated (fig. 7). Individual flood deposits typically were separated from each other by evidence of a temporal hiatus including layers or isolated clasts of rockfall, weak soil development, intervening units of poorly sorted slope wash or other locally derived material, and bioturbated alcove or cave floor deposits.

Stratigraphy was described at each site and recorded in field notebooks. Field descriptions included color, texture, degree of sorting, bedding, grain minerology if known, presence of organic material, and structure, along with any other notable features. A key indicator of fluvially derived material in the study reach was the presence of mica grains, first noted during

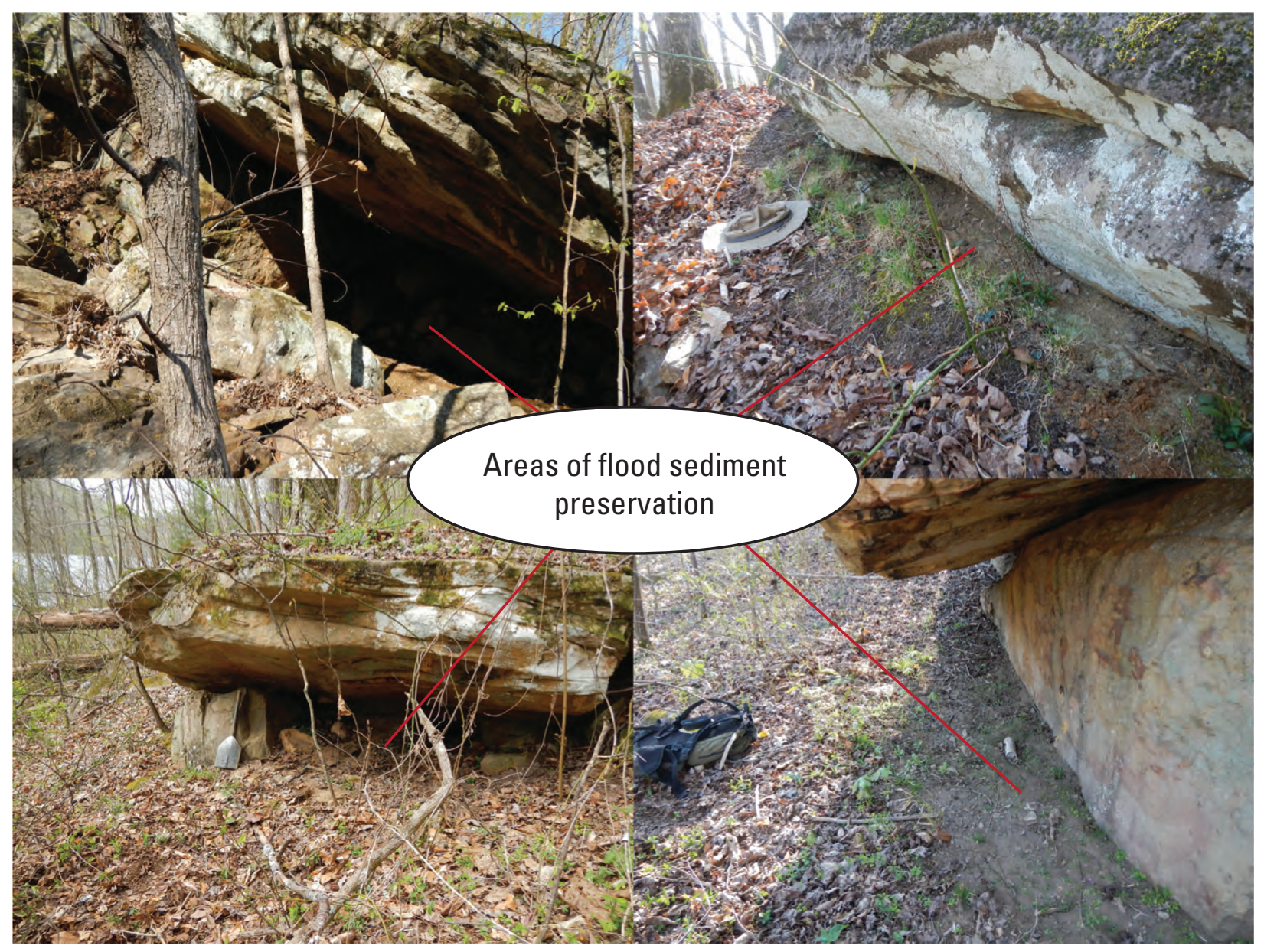

Figure 6. Boulder alcoves where sediments providing evidence of paleofloods are deposited and preserved for hundreds to thousands of years, in the Tennessee River Gorge, Tennessee. 


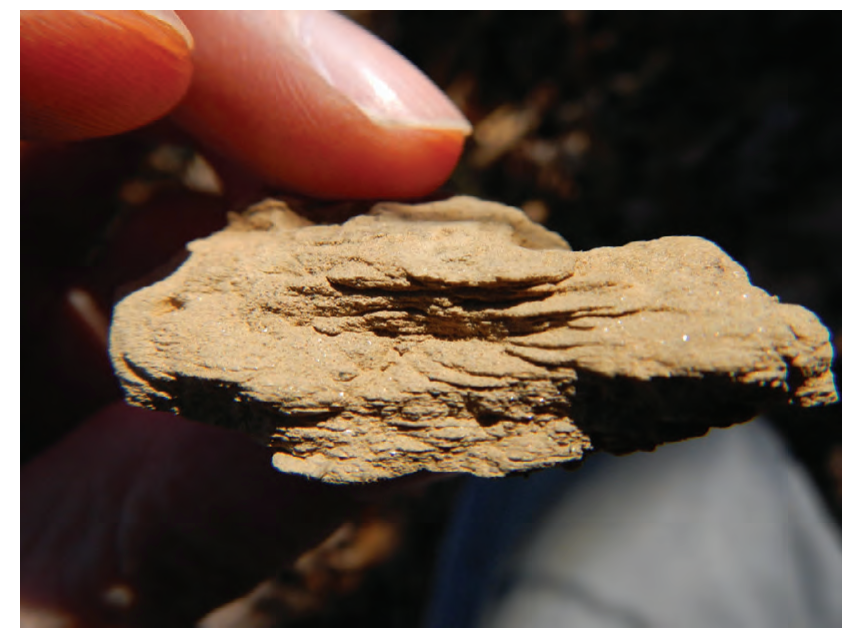

Figure 7. Laminated flood deposit likely from the 1867 historical flood on the Tennessee River, Tennessee.

the feasibility study (Harden and O'Connor, 2017). Modern Tennessee River sediments are rich in mica sourced from the metamorphic and igneous headwaters of the Blue Ridge Mountains. The local geology of the gorge mainly is composed of sandstone and limestone and contains only microscopic mica. Therefore, the presence of mica in a deposit, along with supporting evidence, strongly suggests far-travelled Tennessee River flood sediment.

\section{Geochronology}

The stratigraphic interpretations provided information on the number of floods and their relative ages, with more recent flood deposits on top of, or inset against, older deposits. Ages of individual flood deposits and the total length of record preserved in the stratigraphy were obtained by standard geochronologic techniques.

The primary geochronologic technique used in this study was radiocarbon analysis using carbon-14 $\left({ }^{14} \mathrm{C}\right.$; Stuiver and Polach, 1977). Dated organic material—primarily charcoal; wood fragments; seeds; leaves; and, in one case for this study, a rodent fecal pellet - constrained the ages of deposits. The ${ }^{14} \mathrm{C}$ method is premised on plant photosynthesis, by which atmospheric carbon is incorporated in their tissue, including the radioisotope ${ }^{14} \mathrm{C}$. When the plant dies and photosynthesis stops, the amount of ${ }^{14} \mathrm{C}$ within the plant material systematically declines at a rate governed by the ${ }^{14} \mathrm{C}$ half-life of 5,730 plus or minus $( \pm) 40$ years. Thus, the abundance ${ }^{14} \mathrm{C}$ in a given sample, relative to the stable isotope of carbon-12 $\left({ }^{12} \mathrm{C}\right)$, indicates the time since plant death and an age for the sample. An inherent assumption for paleoflood hydrology is that the time of plant death closely approximates the age of the deposit in which the organic material was found. But this is only true if plant death coincides with incorporation into the deposit. In general, the time between plant death and deposit incorporation (for example by entrainment in a flood and subsequent deposition) can be considered short, especially for delicate organic materials such as leaves and fine twigs not likely to survive long on the surface, particularly in the humid southeastern United States. However, more durable organic materials, particularly charcoal and large wood fragments, may persist for long periods before incorporation in a deposit, or may even recycle through multiple episodes of deposition and erosion. Such organic materials can give erroneously old ages for their enclosing deposit (Blong and Gillespie, 1978). Therefore, the best materials for radiocarbon dating are twigs, leaf fragments, and similar organic materials, which are unlikely to persist when exposed to the elements. Additionally, the most secure interpretation of radiocarbon ages is that the age of the organic material within a stratigraphic unit gives a maximum age of the deposit - in other words, the enclosing deposit must be the same age or younger than radiocarbon ages of detrital organic materials contained within the deposit. However, for delicate materials, the age discrepancy likely is small. At sites with extensive bioturbation from plants, insects, and animals, organic material may move from its original position in the stratigraphy and get redistributed into either older or younger deposits leading to erroneous ages for the deposit dated. The potential for this error is minimized by collecting single organic samples (rather than bulk) and by carefully inspecting stratigraphy to ensure that the dated material has not been emplaced by post-deposition vegetation growth or bioturbation.

In addition to uncertainty that can be introduced by the stratigraphic context of the sample, the resulting ${ }^{14} \mathrm{C}$ analysis and conversion to sample age introduces uncertainty. In particular, the ratio of ${ }^{14} \mathrm{C}$ to ${ }^{12} \mathrm{C}$ in the atmosphere, biosphere, and hydrosphere has varied; consequently, radiocarbon ages based on the historical ratio diverge from true calendar ages. For this reason, all radiocarbon ages were converted to calendar ages using established calibration procedures. For radiocarbon ages less than about 300 years, the resulting uncertainties in the calendar age are especially large because of the large and varying quantities of ${ }^{12} \mathrm{C}$ released into the atmosphere by anthropogenic burning of fossil fuels (Walker, 2005). Radiocarbon ages of from 60 to about 300 years before present (BP) are difficult to distinguish from each other, hindering more precise dating of individual flood deposits from this time period (Taylor, 2001). Samples of organic materials photosynthesizing after A.D. 1950 have particularly high ${ }^{14} \mathrm{C}$ levels because of substantial ${ }^{14} \mathrm{C}$ introduction into the atmosphere by above-ground nuclear testing, and such post-1950 ages are simply noted as "modern."

In this study, sites were selected based on the likelihood of flood deposit preservation. The focus was on sites with reduced bioturbation from plants, animals, and insects. We prioritized dry, sheltered sites with limited vegetation growing on the surface. Intense bioturbation can blur or erase stratigraphic contacts between deposits, making identification and interpretation of unique flood deposits more difficult. Care was taken to choose in-place organic material for radiocarbon analysis from well-defined stratigraphic deposits. 
Organic samples were collected from flood deposits as well as from intervening deposits of local material. Samples were collected as we examined and described site stratigraphy to avoid possible later ambiguity in stratigraphic context. Samples were collected by hand using a metal spatula, trowel, or knife and placed in sealable plastic bags. The nature of the material, its location in the section, and depth below the surface were recorded for each sample. For some flood deposits without individual pieces of visible organic material, bulk sediment samples were collected and more closely examined later to identify datable fragments of organic material. From 74 collected samples, the 28 samples submitted for radiocarbon analysis were selected (1) on the basis of judgments regarding the relative importance of individual deposit sequences for understanding the overall flood history; (2) to obtain ages for the largest floods; and (3) to determine the length of depositional records at key sites, typically by selecting samples from near the base of deposit sequences. Results from basal units guided selection of additional analyses. Additionally, multiple samples from some individual flood deposits (or intervening layers) were submitted to confirm key ages or to reduce ambiguity for cases where ages from previously analyzed samples were inconsistent with stratigraphy. For all samples, ${ }^{14} \mathrm{C}$ activity was measured by accelerated mass spectrometry, either by Aeon Laboratories in Tucson, Arizona, or by Beta Analytic in Miami, Florida.

Radiocarbon results include the uncalibrated radiocarbon age \pm the analysis error of one standard deviation (1- $\sigma$ or 1-sigma). The uncalibrated radiocarbon ages were then converted to calendar year ranges by calibration curve (Bronk Ramsey, 1994) as implemented by the radiocarbon calibration program Oxcal version 4.3 (Bronk Ramsey and others, 2001; Bronk Ramsey, 2009; Reimer and others, 2009). In addition to the uncalibrated analysis results, we report the calendar year calibrations as well as the resulting two standard deviation (2- $\sigma$ or 2-sigma) calibration uncertainties. Because the amount of atmospheric ${ }^{14} \mathrm{C}$ has varied through time, the results are a range of calendar years, or in many cases, multiple calendaryear periods. For example, a radiocarbon date of $1184 \pm 25{ }^{14} \mathrm{C}$ years BP will calibrate to a two-sigma calendar year range of A.D. $770-895$ and A.D. $928-941$.

Optically stimulated luminescence (OSL) is another geochronologic method commonly used to date fluvial deposits. We applied this method for some sites where no datable organic material was found during stratigraphic examination or to confirm or reduce ambiguity from radiocarbon analysis results. OSL dating relies on accumulation of free electrons from the radioactive decay of naturally occurring radioisotopes such as uranium (U), thorium (Th), and potassium-40 (K) (Walker, 2005). Sediment deposits containing or near radioactive isotopes are subjected to low levels of radiation. The electrons derived from the radioactive decay accumulate in structural defects in the crystal lattice of a mineral grain - in this case, quartz. The electrons remain trapped in the crystal lattice until they are exposed to light. Once exposed to light, the electrons are stimulated and released. In the laboratory, these released electrons can be measured and correlated to the amount of time the electrons have been accumulating, or similarly, the amount of time the sediment has been buried. This indicates the age of sediment deposition and burial by a flood in fluvial deposits or by slope processes in local deposits. Favorable factors of successful OSL dating include geology containing naturally occurring radioactive isotopes, quartz, and an abundant source of fine-grained sand.

The use of OSL to date fluvial sediments is widespread but also has limitations. In turbid floodwaters, the amount of sunlight reaching sand grains might be insufficient to reset the OSL signal prior to deposition. The same is true for flood sediment transport and deposition during the night. This incomplete resetting or partial bleaching of the signal within grains can lead to an overestimation of the actual age of the last burial (Wallinga, 2002). Although still an issue, recent analysis techniques can help account for partial bleaching (Rittenour, 2008; Cunningham and others, 2015).

Sediment samples for OSL analysis were collected in $2-5 \mathrm{~cm}$ diameter plastic tubes $10-20 \mathrm{~cm}$ long. The tubes were hammered horizontally into freshly exposed flood sediments in locations selected to avoid large rocks and post-depositional disturbances such as bioturbation, large roots, or desiccation cracks. Aluminum foil was packed into the exposed end of the tube to minimize sample movement in the tube during transit. Tubes were capped, wrapped in aluminum foil, and sealed with opaque tape to prevent light exposure. For sampling under bright conditions, an opaque cloth was used to cover and shield sample collection. Bulk sediment samples of $600 \mathrm{~g}$ or larger were collected in sealable plastic bags for measurement of water content and dose rate. In total, eight samples were collected, with five samples analyzed by the USGS Luminescence Dating Laboratory in Lakewood, Colorado (U.S. Geological Survey, 2019b). Results from the OSL laboratory include measures of the field moisture and radiation level as well as scatter percent and deposit age in years before present. Scatter refers to variability in equivalent dose $\left(D_{e}\right)$ between grains. The $\mathrm{D}_{\mathrm{e}}$ is the laboratory-produced radiation dose that is equivalent to the natural luminescence emission of the quartz grains. Scatter may be caused by partial bleaching of the quartz grains prior to deposition or other processes such as grain-to-grain variability in the natural dose rate (Cunningham and others, 2011). Scatter greater than 20-30 percent is considered poorly bleached or mixed sediment (Murray and others, 2012), and results from samples with such high levels of scatter should be treated with caution (Galbraith and Roberts, 2012).

\section{Hydraulic Modeling}

The elevation of a flood deposit gives a minimum estimate for the peak stage of the emplacing flood (Baker, 1987; Kochel and Baker, 1988). The highest deposits left by a specific flood may closely approximate the peak stage (Webb and others, 2002), although maximum flood stages may exceed 
the highest deposits in many cases (Harden and others, 2011). Estimates of emplacing discharge are obtained by relating stage evidence to channel geometry by hydraulic calculations. These calculations typically are based on modern channel and valley topography. This introduces an additional assumption that changes in channel geometry have been sufficiently small during the time represented by the stratigraphic record to not substantially affect calculations of flow rate associated with specific deposit elevations. This assumption likely is valid in the bedrock-confined boundaries of the Tennessee River Gorge, where the common presence of bedrock near the current channel bottom (Tennessee Valley Authority, 1940) and along valley margins indicates overall stability, particularly for the less than $(<)$ 5,000-year analysis period. Although changes in channel and valley geometry likely are small for the timeframe of the paleoflood records, minor mass wasting and downed timber possibly have locally affected flow hydraulics. No evidence, however, of large-scale mass wasting was discovered during our investigations, so such events are unlikely to have substantially affected results.

A key aspect of any paleoflood study is the estimation of flood magnitudes associated with flood evidence preserved in the stratigraphic record. For this analysis, we developed a 1D hydraulic model for the study reach from which we compared deposit elevations to calculated water-surface profiles for a range of discharges. Two key components are determination of deposit elevations and developing a robust hydraulic model.

To obtain accurate elevations of the flood deposits, the elevation of all sites in this study were surveyed in winter (leaf-off) by a TVA survey crew using real-time kinematic Global Positioning System with $<0.10 \mathrm{ft}$ vertical accuracy (Kubas, 2017). Site locations and elevations were measured using North American Datum of 19832011 horizonal datum and North American Vertical Datum of 1988. Historical Tennessee River flood elevation profiles published by the Tennessee Valley Authority (1940) used the National Geodetic Vertical Datum of 1929; however, in the study area, the conversion between the datum is less than $0.08 \mathrm{ft}$ (National Geodetic Survey, 2019).

The hydraulic modeling was based on a 1D steadyflow U.S. Army Corps of Engineers (USACE) Hydraulic Engineering Center (version 4.1; Brunner, 2010a, 2010b) River Analysis System (HEC-RAS) model for the Tennessee River previously developed by the TVA (Kubas, 2017). The TVA hydraulic model is referred to as the "naturals" model and is described as a combined hydrologic and hydraulic model created by removing the majority of dams from the operational TVA basin hydrology and hydraulics models and changing any factors necessary to represent a condition of the river with no dams (Kubas, 2017). The 1D steady state, subcritical algorithms in HEC-RAS assume gradually varied flow (slopes $<1: 10$ ) in order to use the direct step method to solve the energy equation (Brunner, 2010b). The TVA "naturals" HEC-RAS model met the requirements of subcritical flow for the high flows being considered with very low gradient channel slopes ranging from 0.00023 in the upper section and Chattanooga, to 0.00027 in the Tennessee River Gorge. The model was developed mainly from the TVA-validated Simulated Open Channel Hydraulics model (Tennessee Valley Authority, 2014) and HEC-RAS tributary models. Pre-dam bathymetry and topography were geo-referenced and based on USACE bathymetric surveys, digital terrain data from State and local databases, and USGS topographical maps (Tennessee Valley Authority, 2015).

For the purposes of this study, a 215-mi reach (fig. 8) was extracted from the full TVA "naturals" model. The shorter reach encompassed the main-stem Tennessee River between RM 499 to RM 284. This shorter reach was selected so that initial conditions specified at the downstream analysis-reach boundary did not influence model results at the paleoflood sites. The selected reach takes advantage of a stable and unmodified location to establish a downstream stage-discharge boundary condition. The shorter reach includes three subreaches to account for changes in gradients, sinuosity, and storage, and other changes characteristic of the channel and overbank areas. The uppermost sub-reach of the Tennessee River begins downstream from the confluence with the Hiawassee River at RM 499 and extends downstream to RM 471 to the present-day location of Chickamauga Dam (which is not included in the "naturals" model; fig. 8). The next sub-reach extends from RM 471, through the low-gradient wide valley hosting Chattanooga (with many backwater areas represented in HEC-RAS as storage areas) to RM 454, just downstream from Williams Island. The next downstream subreach, the Canyon sub-reach beginning just downstream from Williams Island, is narrow and confined by the bedrock walls of the Tennessee River Gorge (fig. 5). The Chickamauga Dam and Canyon sub-reaches include all the paleoflood sites in this study (RM 455-443). Downstream from the Canyon subreach, the river widens out into present day Nickajack Lake.

The cross-sectional spacing, floodplain topography, and channel bathymetry in the original "naturals" model is composed of measurements and previous models combined over time and generally discussed in Tennessee Valley Authority (2014). Within the shortened model, methods of data acquisition, accuracy, and spacing of channel bathymetry and floodplain topography vary among the sub-reaches mentioned in the preceding paragraph. Here, the bathymetry and topography are described based on accuracy and likely method of data acquisition from observations of the model geometry. In the Chickamauga Lake sub-reach (fig. 8), cross sections were spaced at intervals of about 1.5-2 miles. The floodplain topography in the model likely is extracted from a 20 -ft USGS 7.5-minute topographic map. The in-channel bathymetry apparently is derived from points surveyed at spacing intervals averaging about $90 \mathrm{ft}$, and less than $250 \mathrm{ft}$, at sub-foot vertical accuracy. Cross sections for the Chattanooga and Canyon subreach were irregularly spaced from $<500$ to 2,000 feet apart, which better characterized the hydraulics of the meandering channel and allowed for connection to storage areas in the flats of the Chattanooga area. The floodplain topography and the in-channel bathymetry are gathered at about 3 -ft cross-channel 


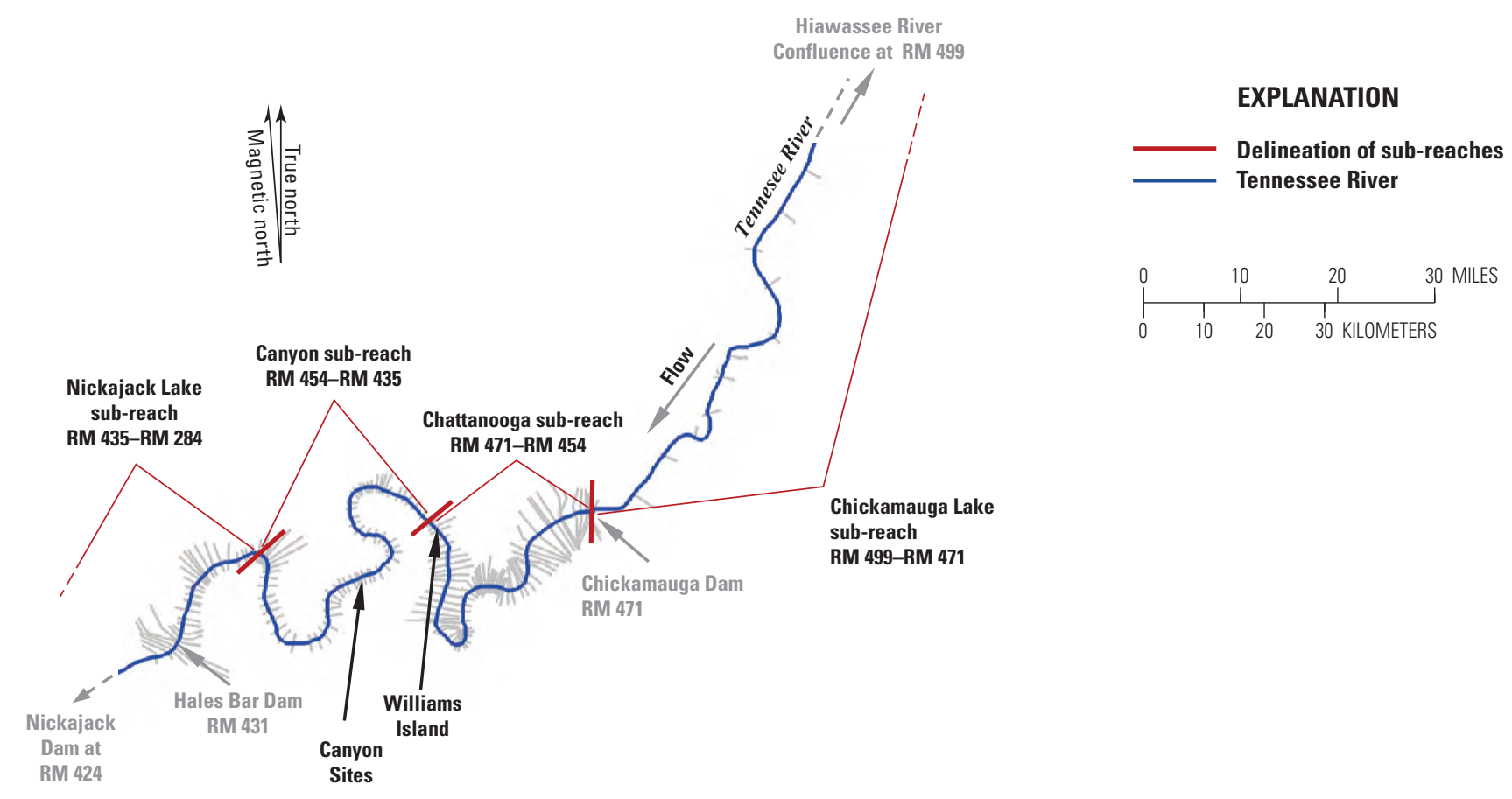

Figure 8. Main reach and sub-reaches of the hydraulic model used in this study of the Tennessee River Basin, Tennessee.

point spacing with sub-centimeter vertical accuracy, apparently obtained from multi-beam lidar, and (or) detailed surveying (for example, U.S. Geological Survey, 2020; Tennessee Department of Finance and Administration, 2020). Downstream in the Nickajack Lake sub-reach, cross sections are spaced from about 500 to 2,000 feet apart, here with crosschannel point spacing about 10 feet apart and sub-foot vertical accuracy.

Because cross sections were widely spaced, additional cross sections were added by interpolation to reduce the calculated energy loss between cross sections to maintain the validity of the assumption of gradually varied flow. Sensitivity analyses showed little effect on water-surface elevations from adding interpolated bathymetry to the model.

Boundary and initial conditions for the shortened model used in this study were developed from the TVA full "naturals" hydraulic model. To quantify the downstream boundary condition, the full-length model domain was run for a range of flows. From this, the stage-discharge rating curve was established at the downstream boundary (RM 284) and input as the initial boundary condition in the shortened model used in this study. Initial conditions for each run in the shortened model were developed for overland contributions and tributary flows based on a relation with the Chattanooga streamgage. The overland and tributary flows were accounted for in the hydraulic model using pre-dam output data from the USACE hydrologic model HEC-HMS, for a set of storm peaks from 1920 to 1930, as part of the TVA "naturals" model (Tennessee Valley Authority, 2014; Kubas, 2017).
For this study, model runs were calibrated to documented high-water marks for three historical floods occurring in the following years prior to dam construction: 1867,1875 , and $1886\left(459,000 \mathrm{ft}^{3} / \mathrm{s}, 410,000 \mathrm{ft}^{3} / \mathrm{s}\right.$ and $391,000 \mathrm{ft}^{3} / \mathrm{s}$, respectively, at the Chattanooga USGS streamgage 03568000.). High water marks for these events were plotted in January 1940 (Tennessee Valley Authority, 1940), and the sources of the elevations were summarized in Tennessee Valley Authority (1961). Calibration was based on adjusting Manning's $n$ values, which characterize the surface roughness of the channel and overbank areas. Initial assignments ranged from 0.02 to 0.035 for the mostly unforested reaches outside the Tennessee River Gorge area. In the gorge area, Manning's $n$ was assigned as high as 0.05 for the channel owing to submerged trees and bedrock shoals and as high as 0.12 for the forested overbank areas. After minor adjustment of the Manning's $n$ roughness coefficient during model calibration, the root mean square error in the calculation ranged from $0.67 \mathrm{ft}$ for the $1867 \mathrm{flood}$ to 0.97 for the 1886 flood, with an average across all observations of $0.80 \mathrm{ft}$. From the resulting calibrated model, sitespecific rating curves were constructed for each paleoflood site, enabling estimation of the discharge required to inundate each site (Harden, 2021). To characterize sensitivity of the model to the calibrated Manning's $n$ values, the model was run for Manning's $n$ of \pm 25 percent, which led to an average difference in discharge associated with stage estimates at the paleoflood sites of $18-28$ percent. 


\section{Compiling the Overall Flood Chronology}

The stratigraphy, geochronology, and hydraulic modeling results from all sites along the Tennessee River were distilled into an overall chronology of the number, timing, and magnitude of large floods. This interpretative process involves combining information from all sites and establishing relations of various stratigraphic units within and among individual sites. This was aided by defining two benchmark sites with long records of large floods. Evidence from the two benchmark sites, Jeff-n-Steph and Red Flower, were supplemented by the stratigraphic records, geochronology, and discharge estimates from all other sites. Interpretation of the overall chronology required correlation of flood deposits among all the sites based on relative stratigraphic description and position, age, elevation and discharge estimation.

The typical approaches used for interpreting flood sequences at individual sites and for correlating among sites within a reach possibly could lead to underestimation of the number of floods in the stratigraphic record. A fundamental premise is that deposition of flood sediment requires exceedance of the deposit elevation by flood stage. However, it is possible that a flood exceeding a deposit elevation may do so barely, or for some other reason such as lack of available sediment or because of local hydraulic factors causing erosion, may not leave a recognizable deposit. Additionally, because the stratigraphic analysis relies on evidence of a temporal hiatus for distinguishing individual flood deposits, multiple deposits from floods separated by short intervals of time potentially can be counted as a single flood unit if such evidence of hiatus is weak or obscured because of bioturbation or other factors (Benito and O'Connor, 2013). Correlations among sites were additionally conservative (to not overcount floods) in that stratigraphic records from sites within the study reach were inferred to completely overlap unless compelling stratigraphic or geochronologic information indicated otherwise. This, too, can lead to undercounting of the total number of floods if incomplete but disparate records are not recognized as such, yet are incorporated in the final record. Although knowing the precise ages of flood deposits is not critical for the flood-frequency analysis (Hosking and Wallis, 1986; Blainey and others, 2002), uncertainty in age can affect correlations among flood deposits. In particular, deposits of similar age generally were considered to record the same flood, unless there was compelling stratigraphic or discharge estimate information that indicated they were not derived from the same flood.

These biases most likely lead to possible flood undercounts, meaning that the resulting flood-frequency analyses are more likely to underestimate flood frequency rather than to overestimate it. However, such possible underestimation is minimized by (1) examining multiple sites at multiple elevations to compile the most complete record of the number of floods as well as a range of magnitudes; and (2) focusing the flood-frequency analysis only on the largest, rarest, and most recent floods, in this case the last 4,000 years, for which processes such as bioturbation are less likely to have sufficient time to obscure stratigraphic records.

\section{Flood-Frequency Analysis}

Conventional flood-frequency analysis typically is based on systematic records, such as flood records from streamgages. In the last few decades, however, new statistical methods have proven the value of supplementing gaged records with historical and paleoflood information (Stedinger and Baker, 1987; England and others, 2010; Harden and others, 2011; Greenbaum and others, 2014; Lam and others, 2017). In response to the increasing application of paleoflood studies to flood-frequency analyses, techniques devoted to incorporating paleoflood information are now widely available (Cohn and others, 1997; O'Connell, 1999; O'Connell and others, 2002; England and others, 2003) and are incorporated in the Bulletin $17 \mathrm{C}$ Federal guidelines for flood-frequency analysis (England and others, 2018).

For this study, flood-frequency analyses were done using the USGS software program PeakFQ v7.2 (Flynn and others, 2006; Veilleux and others, 2014), implementing the Guidelines for Determining Flood Flow Frequency-Bulletin 17C (England and others, 2018). Bulletin 17C adopts the Expected Moments Algorithm (Cohn and others, 1997, 2001) - a generalization of the method of moments that can accommodate interval, censored, and binomial-censored data - to fit a logPearson Type III statistical distribution (a distribution defined by a mean, variance, and a skew) to a series of peak flows at a streamgage.

The streamgage record for this study comes from USGS streamgage 03568000, Tennessee River at Chattanooga, Tennessee. This streamgage has been continuously recording annual peaks flow from 1874 to 2008. Regulation upstream from the streamgage began in 1937; hence our flood-frequency analysis only includes the 62 years of natural peak flow records preceding flow regulation.

The PeakFQ implementation software allows specification of dates, discharge intervals of peak-flow events, and perception thresholds. Perception thresholds are a stage or discharge threshold for which a record would provide information on the flood peak in any given year (England and others, 2018). For example, a high cave in the side of a river valley will only accumulate deposits from floods high enough to inundate the cave and leave a deposit. In this instance, the lower bound of perception threshold is the discharge (or stage) at which flood water would enter the cave, assuming each inundation results in an individual deposit. Every year, then, the river of interest can be characterized as having a peak discharge that either exceeded, or did not exceed, that perception threshold. Such perception thresholds commonly vary with time. For example, the cave might represent a perception threshold for records of extreme floods going back thousands of years, but the last several decades might be accounted for 
with a lower perception threshold consisting of flood marks on a bridge, assuming that each time the flow stage reached the bridge, a mark was made. The date of bridge construction could define the beginning of the associated perception threshold. The end member condition is a typical streamgage, for which the lower bound of perception threshold commonly is zero, meaning that each and every year the peak flow is recorded regardless of magnitude. Perception thresholds give some indication to the magnitude of floods when no information is available otherwise. Most critical for flood-frequency analysis is knowledge of how many floods exceeded a specified perception threshold rather than knowledge of the exact flood dates. Perception thresholds can have upper bounds, indicating discharges too large to be recorded; therefore, multiple sites must be examined at multiple elevations during a paleoflood study. If a thorough field campaign is used, such upper bounds are set to infinity because there are few circumstances for which floods are too big to leave records. A range of perception thresholds commonly will provide better resolution on the timing and magnitude of the largest floods; thus, paleoflood studies benefit from multiple sites recording floods of different sizes.

Flood-frequency analyses were done for seven scenarios. Each scenario represents different considerations of the paleoflood and gaged records to assess the sensitivity of floodfrequency estimates to uncertainties in the paleoflood record.

\section{Stratigraphic Analysis and Site Paleoflood Chronologies}

The 2017 paleoflood feasibility study (Harden and O'Connor, 2017) for the Tennessee River briefly described the stratigraphy at two sites and identified several other locations where potential flood deposits were preserved. For this study, the two sites described in Harden and O'Connor (2017) were reexamined and more completely analyzed. We also examined several of the previously identified sites as well as newly discovered sites. Of 30 potential sites identified during reconnaissance for the 2017 report and this study, 17 were fully examined and described. Six of these sites are the primary basis for interpretation of the overall flood records and are described in this section. The other 11 described sites provide mostly ancillary or supporting information and are described in appendix 1. All sites have been given informal names based on local characteristics or site features.

\section{Site Descriptions, Stratigraphy, and Geochronology}

The overall paleoflood chronology chiefly is derived from the analysis of flood deposits preserved in small alcoves and rock shelters within about RM 443 and 454 (fig. 2). These sites are all within the Tennessee River Gorge where the narrow bedrock valley creates stable and sensitive stage-discharge relations. One site, Broken Stem, contains no evidence of floods but instead provides an upper limit to flood magnitudes. Two benchmark sites, Jeff-n-Steph and Red Flower, are described first. Following those two sites, four sites provide additional specific information on paleoflood magnitude and timing used in the flood-frequency analysis scenarios.

\section{Jeff-n-Steph}

Jeff-n-Steph, a large graffiti-marked boulder providing shelter, has one of the highest and most complete records of floods in the study area (fig. 9). The elevation of the surface of the flood deposits, sheltered by the rock overhang, is $651.12 \mathrm{ft}$ above NAVD 88, very close to the stage reached by the 1867 flood at this location (fig. 10; Tennessee Valley Authority, 1940). It was first assessed as part of the 2017 Tennessee River paleoflood feasibility study (Harden and O'Connor, 2017) but reexamined and analyzed for this study. Our reexamination entailed excavation of a $90-\mathrm{cm}$ deep pit about $1 \mathrm{~m}$ to the left
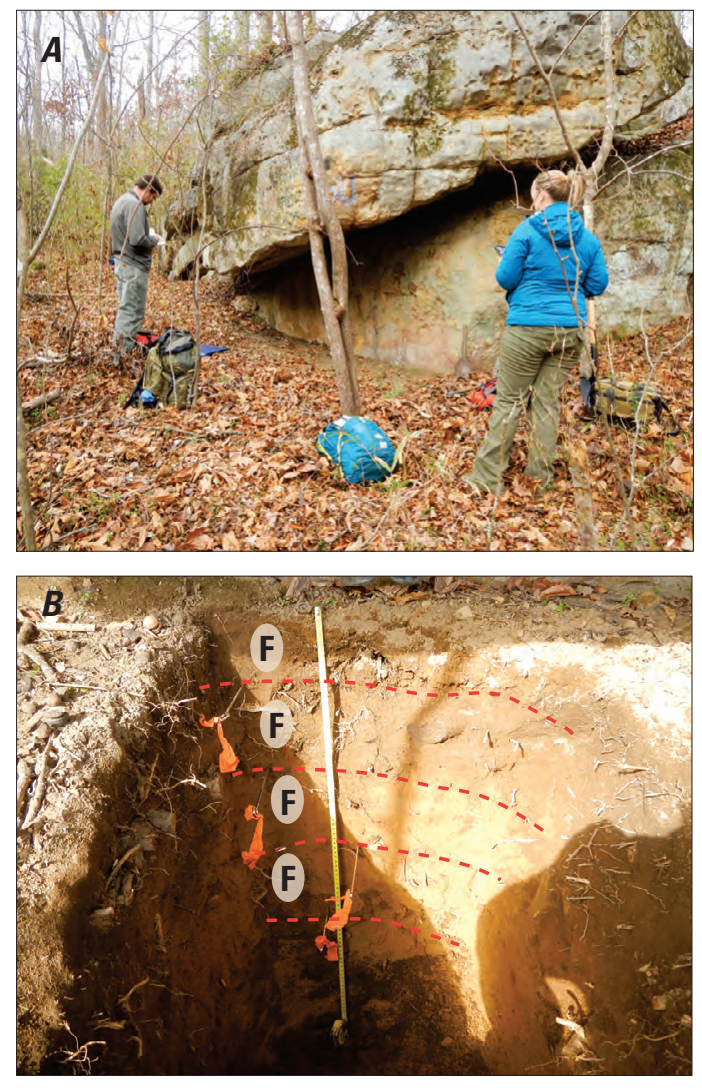

Figure 9. Large boulder creating the rock overhang that helps to preserve the site $(A)$ and stratigraphy of the pit $(B)$, at the Jeff-n-Steph site, Tennessee River, Tennessee. " $F$ " indicates a flood deposit. 

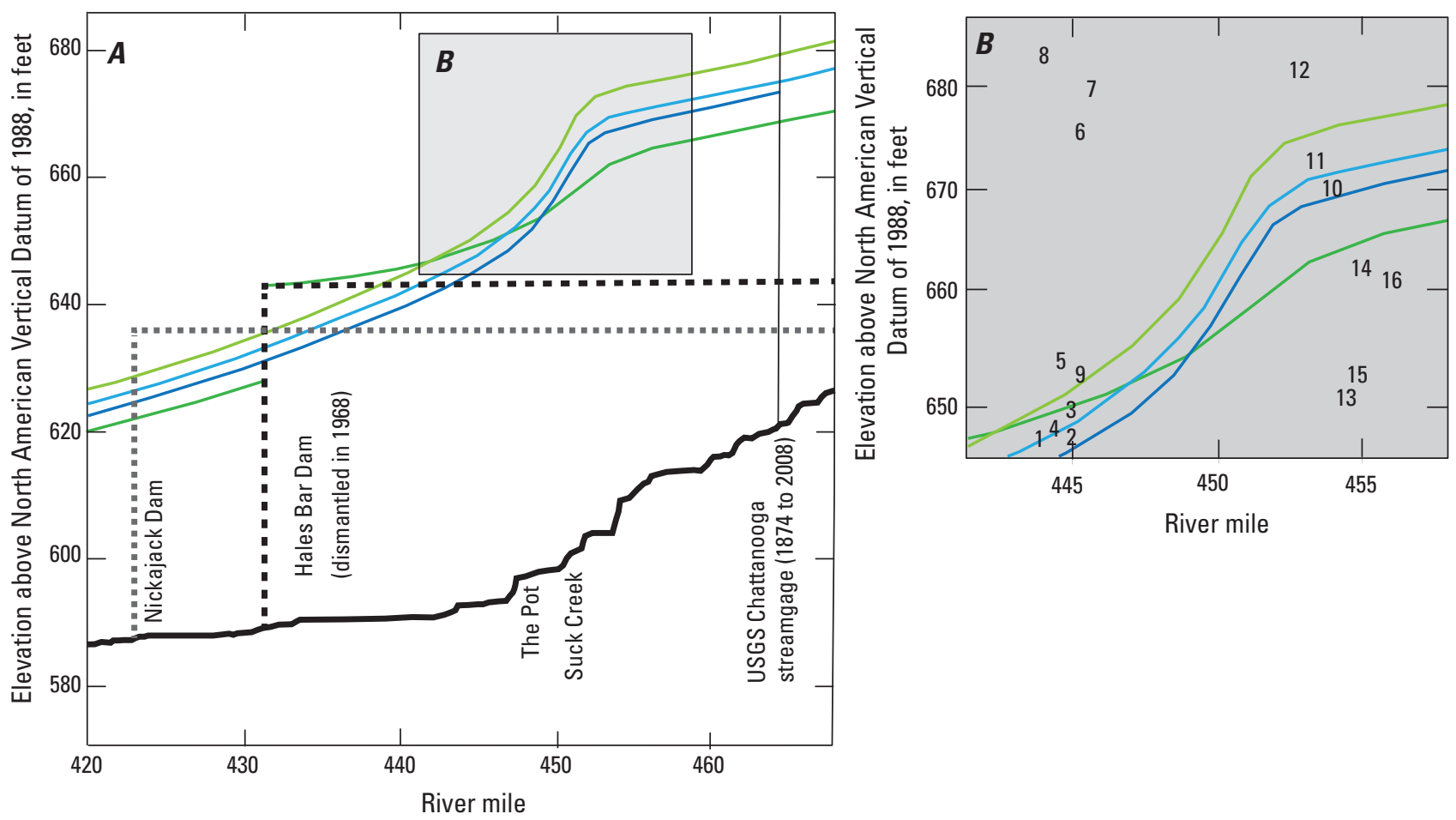

EXPLANATION

Tennessee River at
low flow
Year of peak discharge, and
discharge, in cubic feet
per second
$1867 ; 459,000$
$1875 ; 410,000$
$1886 ; 391,000$
$1917 ; 341,000$

\begin{tabular}{ll}
\multicolumn{2}{c}{ Paleoflood sites } \\
1 Smirnoff & 9 Jeff-n-Steph \\
2 Oven & 10 Last Survey, pits A and B \\
3 Upper Oven and Freezer & 11 Turkey Blind \\
4 Congo & 12 TBM4 \\
5 Milled Wood & 13 Mud Wasp \\
6 Goose Wallow & 14 Buzzard's Cave \\
7 Red Flower & 15 Looter Pit \\
8 Broken Stem & 16 Williams Island
\end{tabular}

Figure 10. Location of paleoflood sites in study relative to elevation and surface water profiles (Tennessee Valley Authority, 1940) from the 1867 historical flood as well as other large floods in the gaged record, Tennessee River Basin, Tennessee. Locations of Nickajack Dam and Hales Bar Dam also are shown.

(downstream) of the pit described in Harden and O'Connor (2017). The stratigraphy of both pits was similar, showing evidence of four distinct Tennessee River floods (fig. 11).

The upper 14-20 cm (thickness varied) of sediment is brown, very fine to fine sand (fig. 11). The upper several centimeters are locally bioturbated and bedding features are not obvious. This unit is well-sorted and very micaceous. This youngest flood deposit is separated from the unit below by a discontinuous stone line of boulder fragments fallen from the overhanging rock, thus indicating a temporal hiatus between deposits. Well-sorted, orange and dark brown mottled silty fine sand is present from about 14 to $31 \mathrm{~cm}$ below land surface (bls). This unit has abundant roots, charcoal fragments, and mica, and is extensively bioturbated. The bottom contact is defined by a distinct stone line. This deposit also is inferred to be a flood deposit. The next $14 \mathrm{~cm}$ are orange, very fine to fine micaceous sand, thereby indicating a distinct flood deposit.

The upper $10 \mathrm{~cm}$ of this unit is bioturbated. The top half of the bioturbated section is mottled and contains abundant charcoal fragments. The bottom contact is defined by a stone layer with angular clasts as large as $7 \mathrm{~cm}$. The next $16 \mathrm{~cm}$ to a depth of $61 \mathrm{~cm}$ bls is similar to the flood deposit above but finer and less bioturbated. This flood deposit overlies a thick and slightly reddened silty fine sand with abundant angular gravel and cobbles as large as $5 \mathrm{~cm}$, which we infer to be locally derived colluvium. In total, four distinct flood deposits are present, each separated by stone lines indicative of depositional hiatuses. 


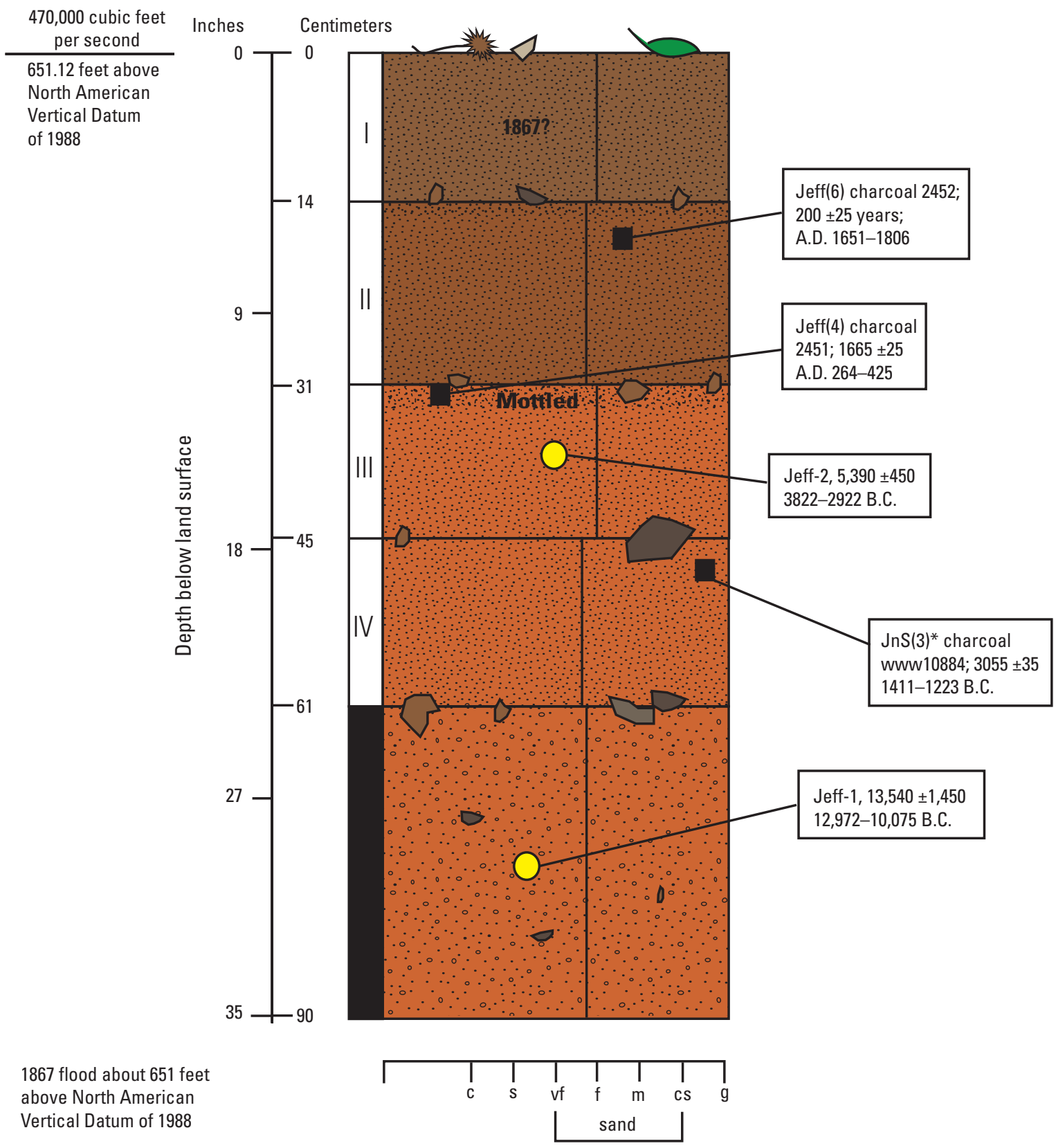

EXPLANATION

\begin{tabular}{ll} 
Rock & \multicolumn{1}{c}{ Grain-size scale (x-axis) } \\
$\mathrm{c}=\mathrm{clay}$
\end{tabular}

Figure 11. Four flood deposits, intervening angular gravel clasts, and deposit of local material at the base of the pit, at the Jeff-n-Steph site, Tennessee River Gorge, Tennessee. Results from the optically stimulated luminescence and radiocarbon dating of the deposits also are shown. 
The stratigraphy at Jeff-n-Steph has been dated by radiocarbon and OSL (tables 2 and 3, respectively). Harden and O'Connor (2017) used a radiocarbon age in the oldest flood deposit to determine that the four floods at this site had all occurred since about 1411-1223 B.C. Two more radiocarbon samples were analyzed from the second and third oldest flood deposits. The third oldest flood deposit contained charcoal dated at A.D. 264-274 and A.D. 331-425, and the second oldest flood contained charcoal dated at A.D. 1651-1684 and A.D. $1735-1806$.

Two units were dated using OSL geochronology. The lowermost colluvial unit partly exposed by the pit was dated at $12,972-10,075$ B.C. The third oldest flood was dated at 3822-2922 B.C. If these ages represent the actual age of the deposits, then the third oldest flood is much older than the radiocarbon results, which makes the fourth flood even older. Although this is possible, ages of floods at other sites, as described in the following sections, are more consistent with the younger radiocarbon ages.

At an elevation of $651.12 \mathrm{ft}$ above NAVD 88, the calibrated hydraulic modeling indicates that the minimum discharge required to inundate the Jeff-n-Steph site is 470,000 $\mathrm{ft}^{3} / \mathrm{s}^{4}$. The elevation is within $1 \mathrm{ft}$ of the 1867 water-surface elevation at this site as reported in the Tennessee Valley Authority (1940) flood profile analysis, which has a reported discharge of $459,000 \mathrm{ft}^{3} / \mathrm{s}$ at the Chattanooga streamgage site 19 miles upstream (fig.10). Although no ages were determined specifically for the youngest flood deposit at this site, it must be younger than A.D. 1651-1806, the age of the underlying deposit, and its elevation is close to the maximum stage of the 1867 flood. Other historical floods were smaller in magnitude and not likely recorded in the stratigraphy at this site. From this information we infer that the youngest deposit at Jeff-nSteph was most likely left by the 1867 flood. The three older floods preserved here must have had discharges similar to or greater than $470,000 \mathrm{ft}^{3} / \mathrm{s}$ and all occurred in at least the last approximately 3,500 years, the likely minimum age of the basal colluvium exposed at this site based on the radiocarbon date of the oldest flood.

\section{Red Flower}

The Red Flower site (fig. 12) is nearly $30 \mathrm{ft}$ higher than and almost directly upslope from the Jeff-n-Steph site (fig. 10). This site, described in the feasibility study

\footnotetext{
${ }^{4}$ In the text of this report, discharge estimates derived from the hydraulic model are reported to two significant digits. The flood-frequency analyses use the precise values as reported in tables 4, 5, and 6 and in the figures of the schematic diagrams of the sites (for example, fig. 11). The results of the floodfrequency analyses are reported in 2 significant figures.
}

(Harden and O'Connor, 2017), is a flat surface abutting a large tilted slab of sandstone embedded in the valley slope. The slab tilts over the site, providing nearly $2 \mathrm{~m}$ of protection from weather. This site was reexamined for this study by digging an additional pit to reexamine stratigraphy.

The 54-cm pit contained evidence of one distinct flood deposit exposed 2-14 cm bls (figs. 12B and 13). This deposit consists of well sorted fine to very fine micaceous sand. The upper 5-6 cm is looser than the bottom $6 \mathrm{~cm}$ and likely has been extensively bioturbated. The sorting and conspicuous mica indicate a Tennessee River flood deposit. The units above and below are poorly sorted and contain abundant angular gravel clasts and granules and no apparent mica. These attributes indicate that these units are locally derived slope wash and colluvium.

Because the stratigraphy and position indicate a single flood much larger than the 1867 flood level, the deposits at the Red Flower site were dated twice using radiocarbon and twice using OSL. Both OSL samples were collected in the locally derived colluvium below the flood deposit and returned ages of 1220-740 B.C. at $18 \mathrm{~cm}$ and 2132-1472 B.C. at $40 \mathrm{~cm}$. The younger date at $18 \mathrm{~cm}$ comes from the original excavation (Harden and O'Connor, 2017). A radiocarbon sample collected at the base of the flood unit in the previous exposure returned age ranges of A.D. 1652-1696 and A.D. 1726-1815. Another charcoal sample collected from the flood deposit in the new excavation provided age ranges of A.D. 1672-1779 and A.D. 1798-1825 in addition to possible age ranges that post-dating A.D. 1798. Considering the radiocarbon results, we infer that this flood must have been in the mid-to-late 1600s. Later plausible ages permitted by the radiocarbon analyses are within the period of historical flood accounts (which extend to the early 1800s) and such a large flood certainly would have been noted.

At an elevation of $679.69 \mathrm{ft}$ above NAVD 88, this site requires a flood stage at least $30 \mathrm{ft}$ higher than the watersurface elevation of the 1867 flood (fig. 10). This is the highest such flood evidence found in the Tennessee River Gorge. The minimum discharge required to inundate this site and deposit the flood sediment is $1,100,000 \mathrm{ft}^{3} / \mathrm{s}$. Based on its likely age, this flood, referred to as the Red Flower flood, likely is the same flood as the second youngest flood preserved at the Jeff$\mathrm{n}$-Steph site. From the ages of the underlying colluvium, the Red Flower flood apparently is the largest Tennessee River flood of the last 4,000 years based on the two OSL ages of the basal colluvium at this site. 


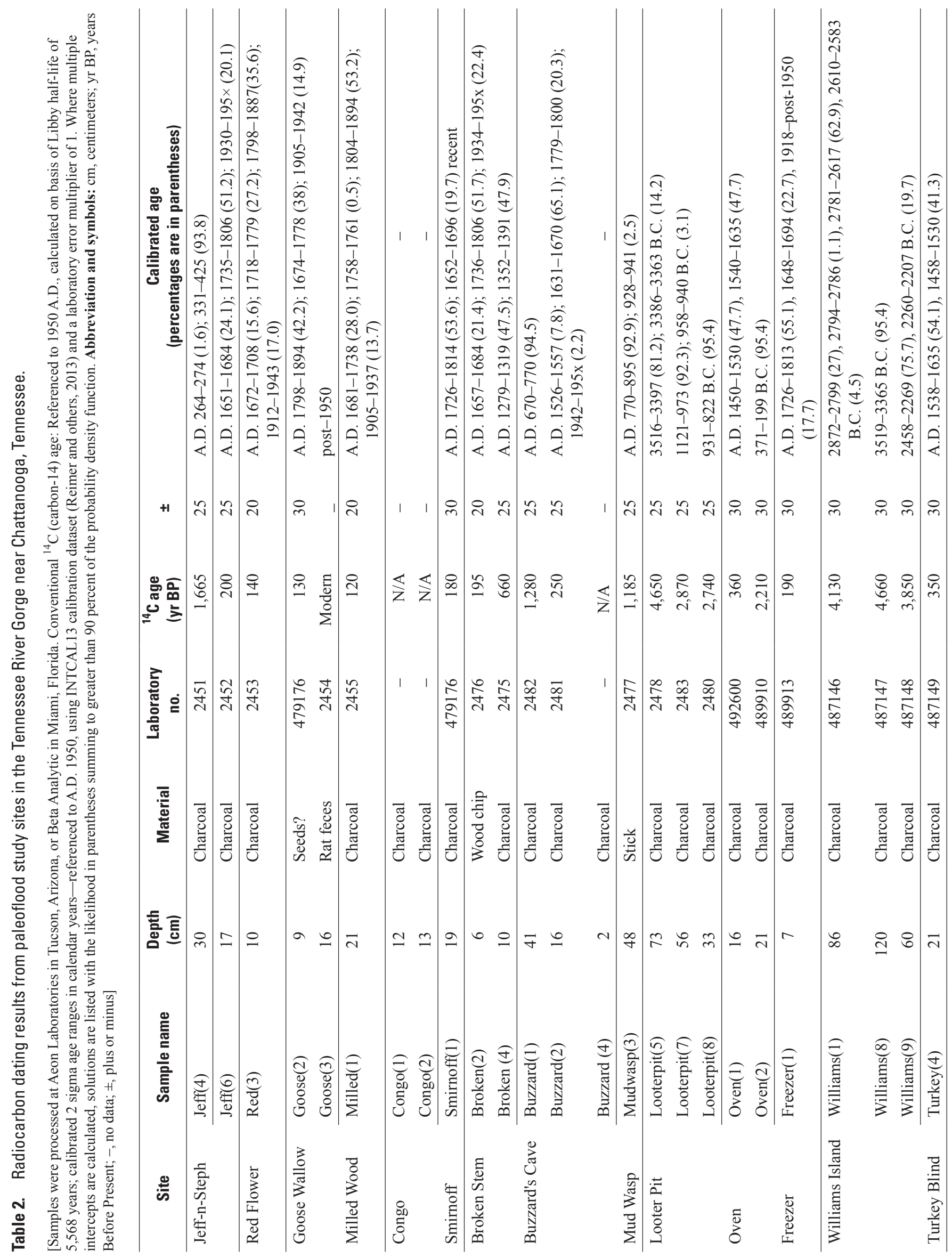




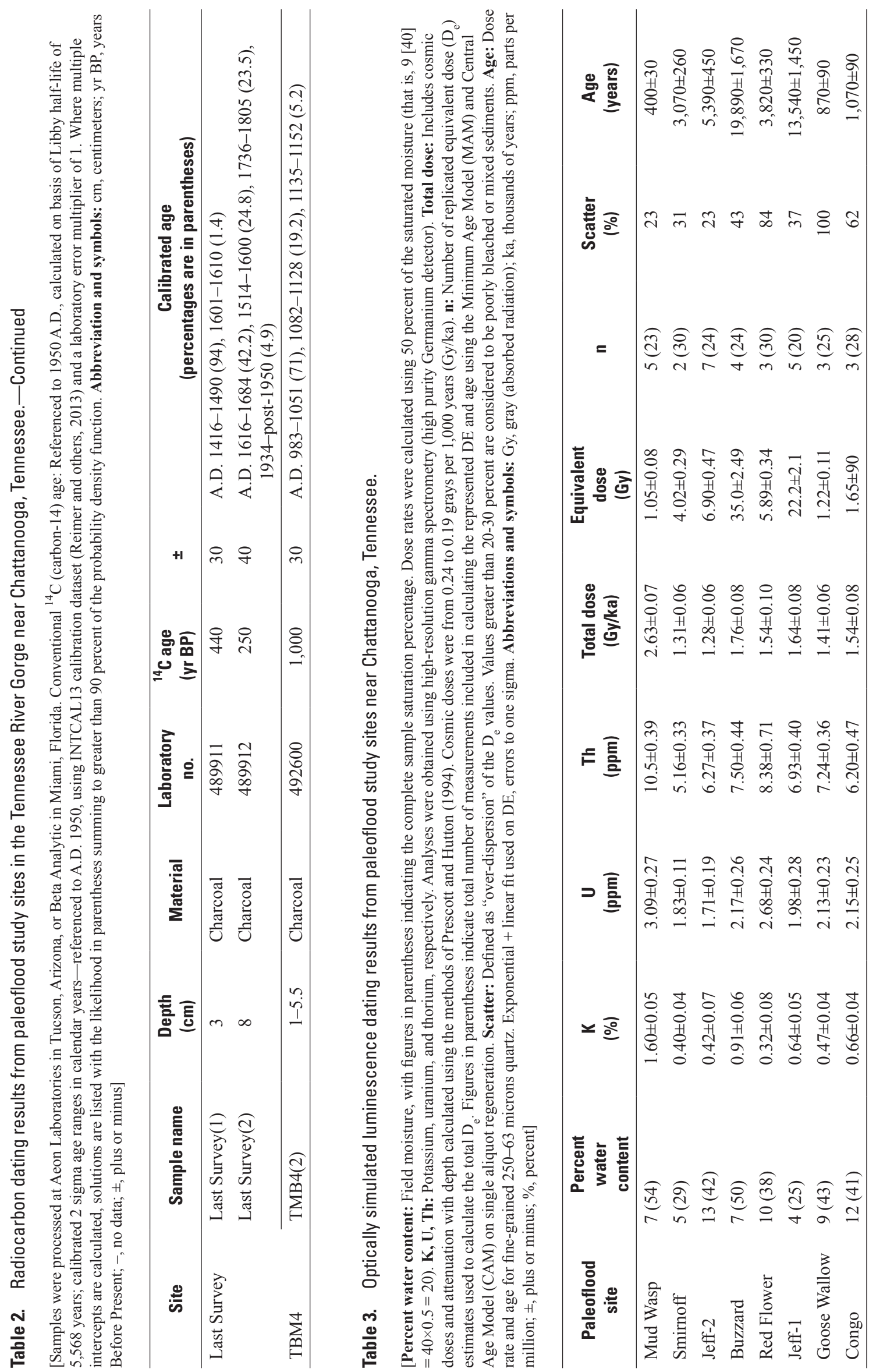



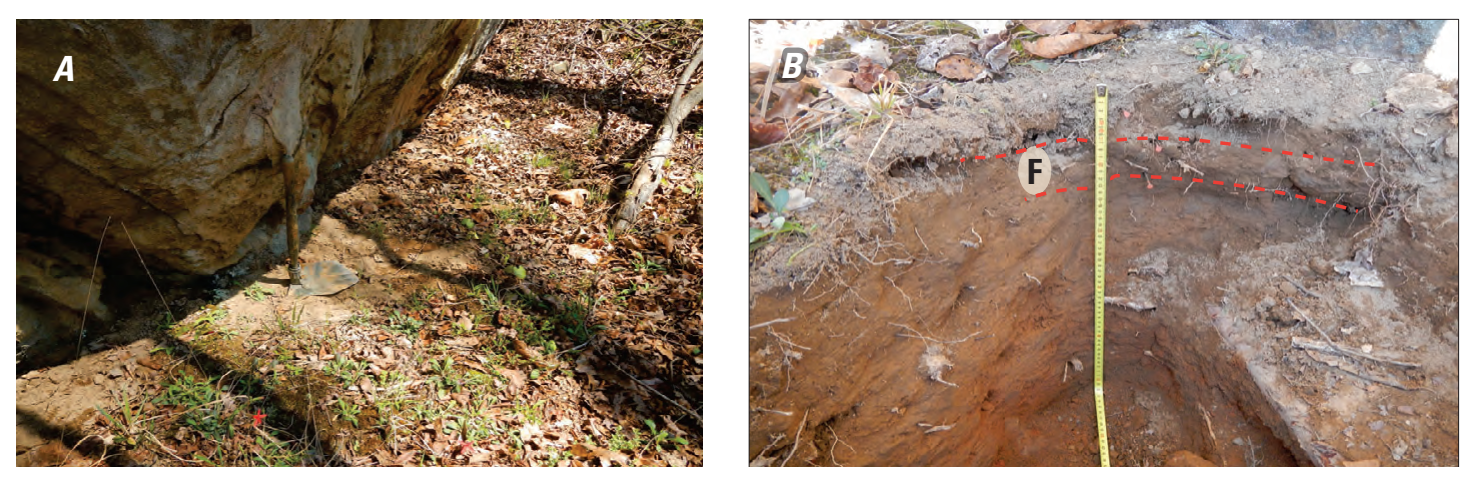

Figure 12. Location of the pit adjacent to a large sandstone boulder $(A)$ and stratigraphy of the pit that includes one paleoflood deposit between deposits of local material $(B)$, at the Red Flower site, Tennessee River, Tennessee. "F" indicates a flood deposit.

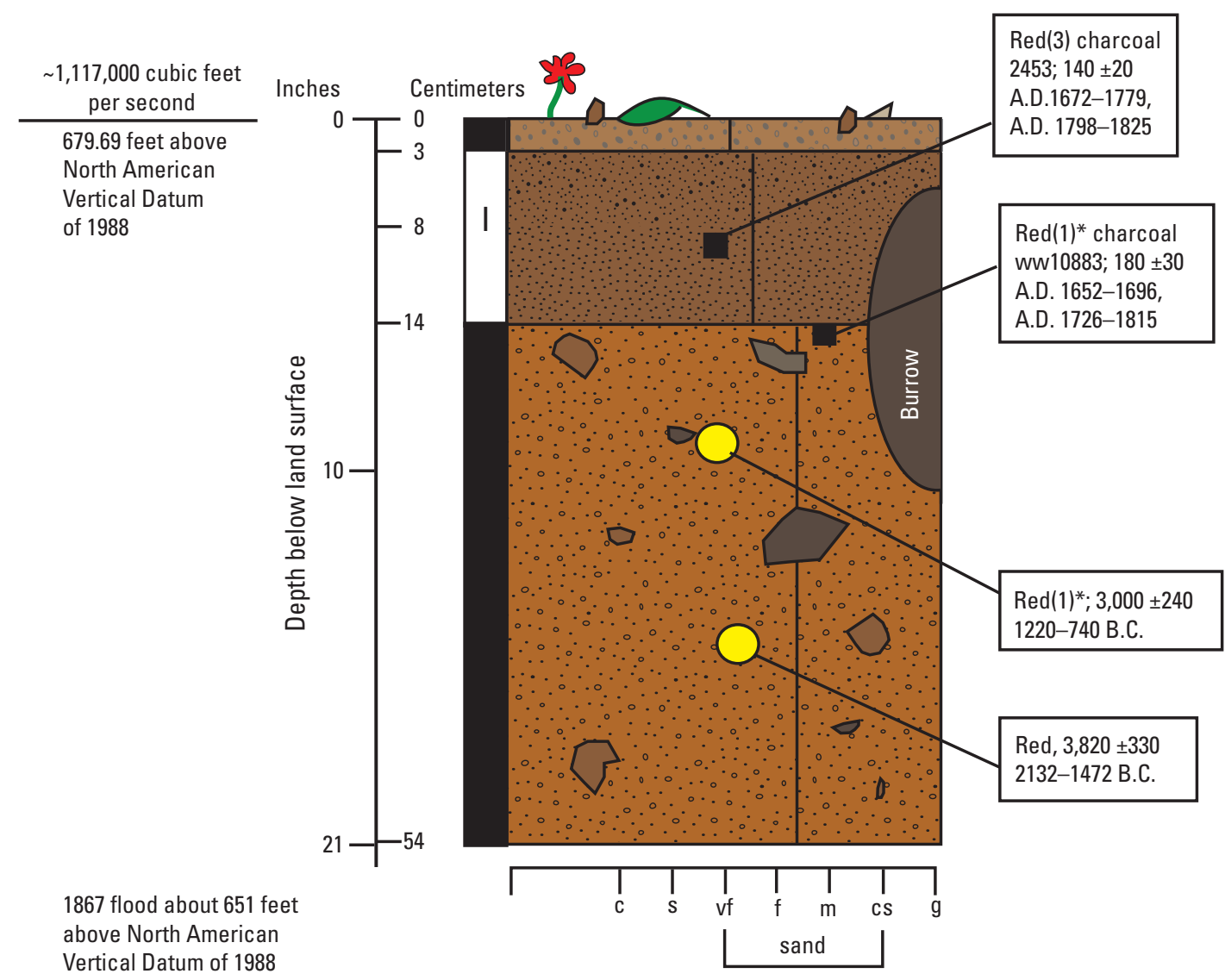

EXPLANATION

$\begin{array}{ll}\text { Rock } & \text { Grain-size scale (x-axis) } \\ \mathrm{c}=\mathrm{clay}\end{array}$

Figure 13. One flood deposit between deposits of local material, at the Red Flower site, Tennessee River, Tennessee. Optically stimulated luminescence and radiocarbon results from the flood deposit and local material below also are shown. 


\section{Congo}

Downstream from the Red Flower site at an elevation of $646.25 \mathrm{ft}$ above NAVD 88 is a hollow cavity within a large boulder that has created an enclosed and flat-bottomed area of about 0.6 -by- $0.9 \mathrm{~m}$ lateral dimensions. A $30-\mathrm{cm}$ pit was dug vertically into sediments accumulated within the cavity to expose the stratigraphy (fig. 14). The top $1 \mathrm{~cm}$ is loose, light brown sand and silt with abundant organic debris and angular sandstone clasts as much as $3 \mathrm{~cm}$ in diameter and appears to be locally derived slope wash and rockfall (fig. 15). Below that to a depth of $9 \mathrm{~cm}$ is brown fine sand fining upward to silty very fine sand. Roots and burrows are abundant especially in the lower $5 \mathrm{~cm}$. The upper few centimeters are more compact and have sub-horizontal wavy bedding. The base of this unit is locally marked by a line of gravel clasts as much as $3 \mathrm{~cm}$ in diameter. Although no mica was clearly visible, this unit appears fluvial and likely is a Tennessee River flood deposit based on its fining upward sequence, wavy bedding, and wellsorted sand. The remaining deposit, at $9-22 \mathrm{~cm}$ in depth, is compact, grayish-brown well-sorted silty fine sand. Mica is visible but sparse. Small dark angular pebbles are abundant at the base of the unit, which lies directly on top of what appears to be large boulders. The well-sorted sand texture indicates that this also is a flood deposit separated from the one above by the line of gravel clasts.

There was no charcoal at this site feasible for radiocarbon analysis but an OSL sample was taken in the oldest flood unit.

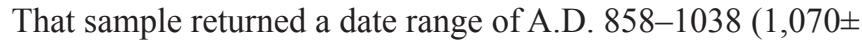
90 years BP). This flood is the same age as the oldest flood found at the Mud Wasp site described in appendix 1, but it represents a higher stage (fig. 10). At $646.25 \mathrm{ft}$ in elevation, the discharge required to inundate this site and deposit the sediment from both floods is about $400,000 \mathrm{ft}^{3} / \mathrm{s}$. The younger flood deposit likely is either a historical flood or the same flood as one preserved at the Jeff-n-Steph or Red Flower sites. Based on its age and elevation, the older flood is evidence of a unique flood in addition to the ones inferred from the stratigraphy of the Jeff-n-Steph and Red Flower sites.

\section{Broken Stem}

To locate the upper limits for the magnitude of midto-late Holocene flooding on the Tennessee River near Chattanooga, we identified sites that had similar characteristics to sites with preserved flood deposits (a relatively dry, flat sheltered area with limited bioturbation) but higher in elevation than about $680 \mathrm{ft}$, or the elevation of the highest Tennessee River flood deposits identified in this study.

One such site is Broken Stem. At $684.1 \mathrm{ft}$ in elevation (fig.16), Broken Stem is the highest site where the stratigraphy was examined in detail, $4.1 \mathrm{ft}$ higher than the Red Flower site (fig.10). Here, a large sandstone boulder creates a relatively wide dry area with limited vegetation and no obvious bioturbation (fig.16). If floods had reached this high in elevation during the Holocene, and especially during the last few thousand years, their deposits would likely have been preserved at this site much as they have at similar sites with lower elevations.

A 36-cm-deep pit was dug at this site (fig. 17). The sediment ranges from silty sandy cobbly gravel with angular sandstone fragments as deep as $20 \mathrm{~cm}$ near the bottom of the pit to pebbly silty sand in the upper $5 \mathrm{~cm}$. The sediment here is poorly sorted and loose in the upper half of the pit and has a high gravel content. This sediment is a mix of local material including roof-fall fragments and slope wash. There is no evidence of fluvially transported material from the Tennessee River at this site.

Two pieces of organic material were collected and submitted for radiocarbon analysis (table 2). A charcoal sample from $10 \mathrm{~cm}$ in depth was dated at A.D. 1279-1319 and A.D. 1352-1391 and a small piece of wood from $6 \mathrm{~cm}$ in depth returned an age of A.D. 1657-1684 and A.D. 1736-1805. Using these dates, we know that the water-surface elevation from a flood on the Tennessee River has not exceeded 684 $\mathrm{ft}$ elevation, which corresponds to a discharge of $1,300,000$ $\mathrm{ft}^{3} / \mathrm{s}$ since at least about A.D. 1279 and probably much longer $(4,000$ years or more) based on the stratigraphy at other sites such as the Red Flower and Goose Wallow (app. 1) sites. Although PeakFQ (Veilleux and others, 2014), the floodfrequency software used in this study, uses perception thresholds to constrain years with unknown peak discharge values, this non-exceedance bound (Levish, 2002) adds confidence to the overall flood chronology and upper limit of paleoflood discharge estimates used in this study.

\section{Last Survey}

The Last Survey site is located at the upstream end of the Tennessee River Gorge (fig. 10). Here, ledgy limestone outcrops provide small areas for deposition and preservation of flood sediment. Two shallow pits were dug into a thin deposit of fine-grained material along a narrow ledge of the limestone outcrop (fig. 18). Pit A, elevation $670.3 \mathrm{ft}$, is $2-3 \mathrm{~m}$ upstream from Pit B, elevation $669.8 \mathrm{ft}$. The two small pits are separated by a vertical section of the limestone bedrock. Pit A contains evidence of two distinct deposits in the $5 \mathrm{~cm}$ of sediment deposited on the ledge (fig. 19). The top $3 \mathrm{~cm}$ are separated from the bottom $2 \mathrm{~cm}$ by an angular limestone clast at the contact as well as a color and texture change. The two deposits are similar in composition, but the younger deposit is finer-grained and browner compared to the underlying orangish-brown fine sandy silt. Both deposits are well-sorted and locally bioturbated. Mica is present in both deposits although it is distinctly more abundant and coarser in the older deposit. Based on this stratigraphy, these two deposits are interpreted as left from individual Tennessee River floods. 

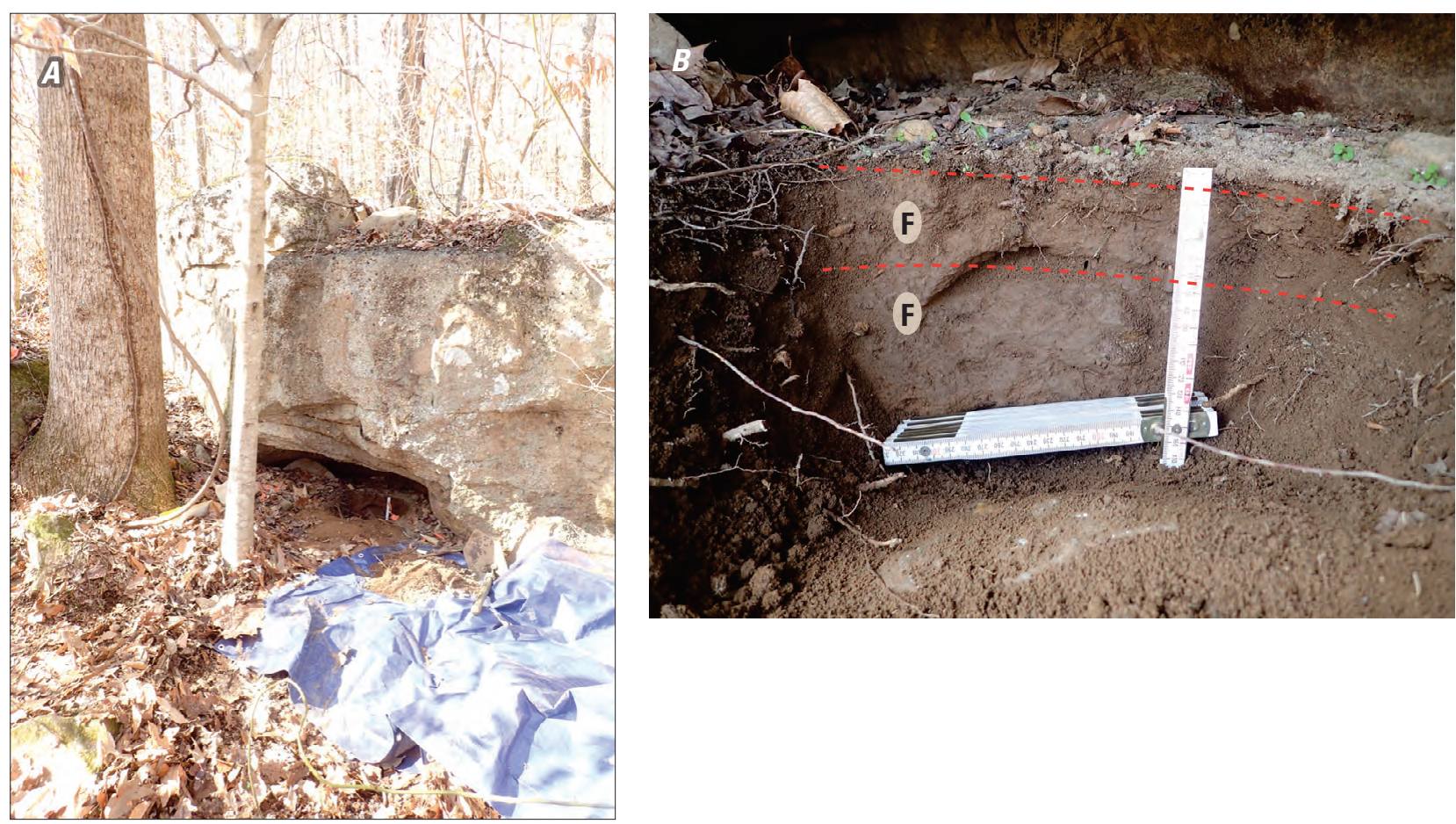

Figure 14. Location of the pit $(A)$ and stratigraphy of the pit including evidence of two floods $(B)$, at the Congo site, Tennessee River, Tennessee. "F" indicates a flood deposit.

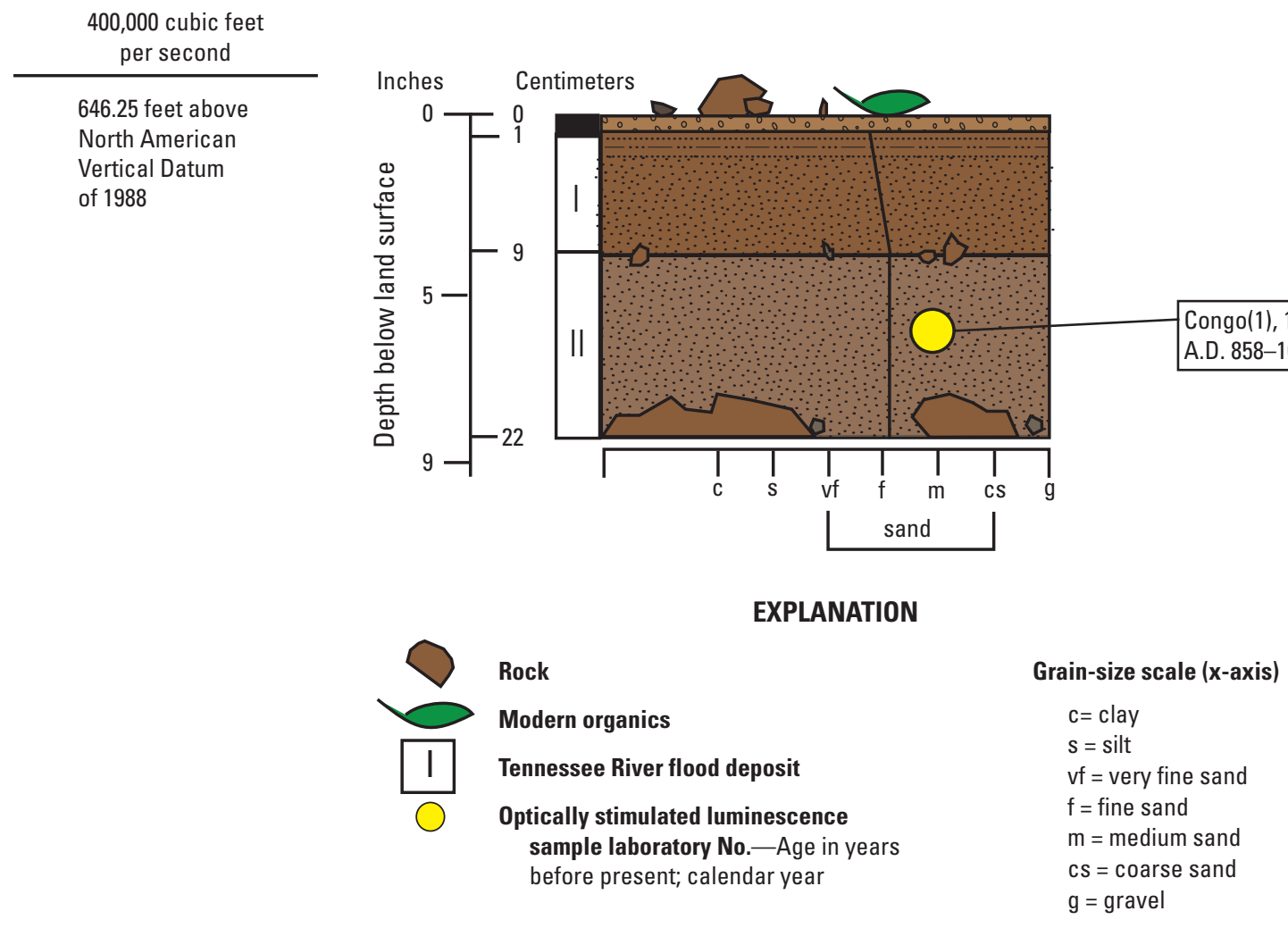

Figure 15. Exposed stratigraphy at the Congo site, Tennessee River, Tennessee. 


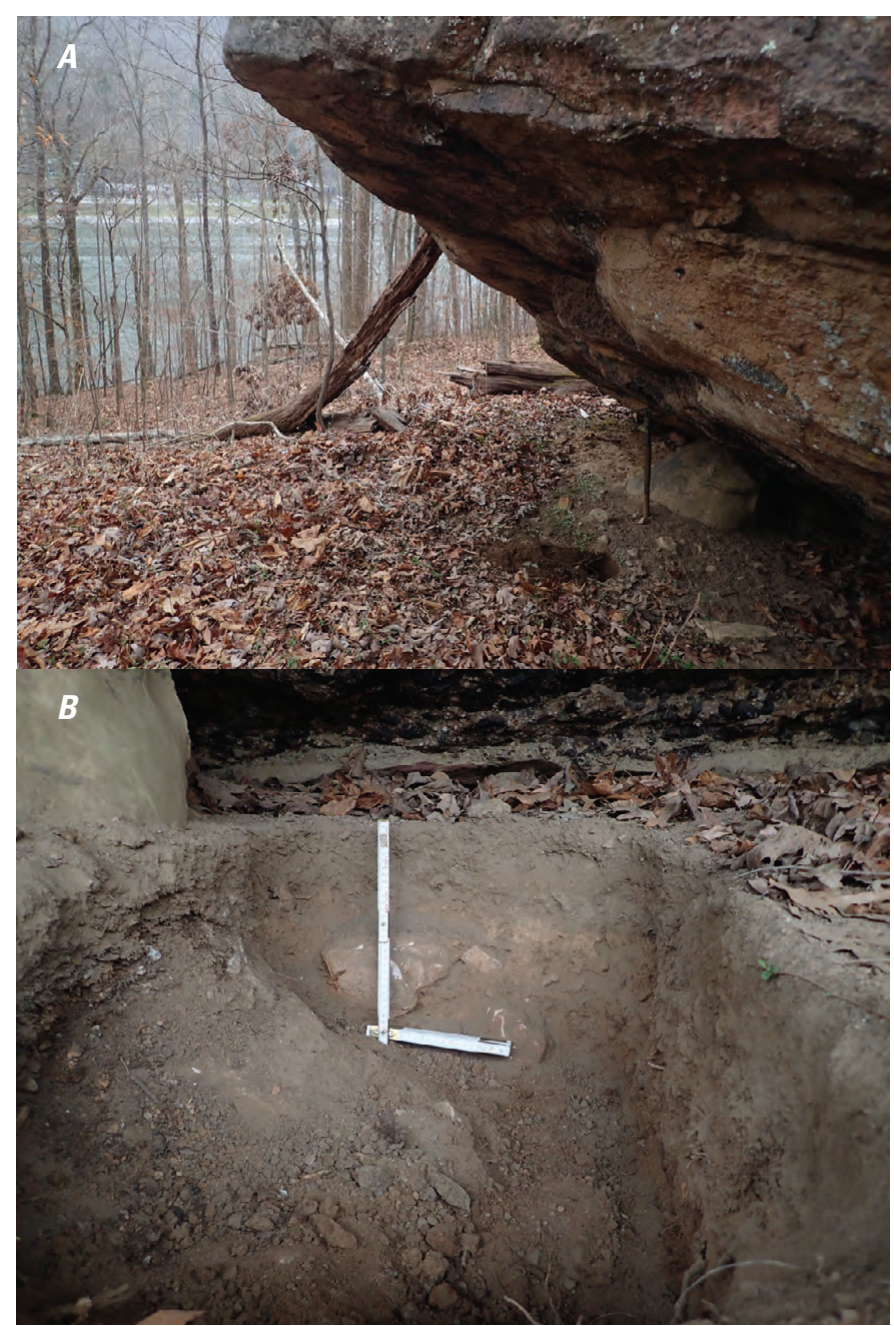

Figure 16. Location of the pit underneath a boulder overhang and relative to the river $(A)$ and stratigraphy exposed in the pit $(B)$, at the broken Stem site, Tennessee River, Tennessee. This site is less than 5 feet above the Red Flower site but contains no evidence of Tennessee River flood deposits.

The stratigraphy in pit B is similar to stratigraphy in pit A (fig. 19). The two deposits here are separated by a distinct semi-continuous stone line at $8 \mathrm{~cm}$ bls. The top deposit is brown silt to very fine sand and the lower deposit is dull orange to tan/brown very fine sand. The lower deposit is distinctly more micaceous and coarser grained than the top deposit.

A piece of charcoal from the top of the oldest flood deposit in Pit A returned calibrated radiocarbon date ranges of A.D. 1416 to 1490 and A.D. 1602 to 1610. In Pit B, a piece of charcoal from near the base of the youngest flood unit gave calibrated ranges spanning multiple periods; A.D. 1514-1600, 1616-1684, 1736-1805 and 1934-post-1950. Based on these dates, the oldest flood here likely dates from the 1400s or 1500 s. This timing does not seem to correspond to any of the deposits at Jeff-n-Steph (fig. 11) but it may correlate to deposits at the Oven, Mud Wasp, and possibly Turkey Blind sites described in appendix 1. The Pit B charcoal piece seems to be too old to have been emplaced by the Red Flower flood, although if the dated charcoal was several decades old prior to incorporation into the flood deposits, that correlation may be possible (and the coarser texture of the lower deposit is consistent with such a scenario). The youngest flood deposit at Last Survey also possibly was left by the large Red Flower flood. This would imply, however, that evidence of the 1867 flood is not preserved here, despite attaining a stage about $3.7 \mathrm{ft}$ above the site elevation (fig. 10). Absence of 1867 deposits might possibly be the consequence of the depositional space being mostly filled by the older deposits. Although this site introduces ambiguity, which we examine in the flood-frequency analyses, our preferred overall flood scenario adopts the oldest flood deposit at Last Survey as a distinct flood in the 1400s or 1500 s.

\section{TBM4}

TBM4 is a high site on the left bank near the upstream entrance to the Tennessee River Gorge (fig. 10). At 682.92 $\mathrm{ft}$ above NAVD 88, its elevation is about 9-10 ft higher than the water-surface elevation of the 1867 flood (674 ft above National Geodetic Vertical Datum of 1029; Tennessee Valley Authority, 1940). The site occupies a 40 by $130 \mathrm{~cm}$ space between a limestone ledge and the hillslope below (fig. 20).

A shallow $10.5-\mathrm{cm}$ pit was dug in the sediment accumulated below the limestone overhang (fig. 21). The upper centimeter is brown crumbly sandy silt with multiple limestone fragments, sticks, and twigs, inferred to be locally derived colluvium mixed with spalled rock fragments from the overlying ledge. The next $4.5 \mathrm{~cm}$ are compact, well sorted brown sandy silt with sparse mica and subtle horizontal laminae especially near the base of the deposit. This is inferred to be a Tennessee River flood deposit. Beneath this are $4 \mathrm{~cm}$ of brown-gray silt with isolated fresh as well as weathered limestone clasts underlain by grayish-green, deeply weathered limestone bedrock. These lower units are inferred to be weathered bedrock of the limestone outcrop and associated locally derived sediment.

When examining the stratigraphy at this site in the field, no single piece of organic material suitable for radiocarbon analysis was identified. But later examination of a bulk sediment sampled from the flood deposit yielded a small charcoal fragment. This charcoal fragment gave calibrated radiocarbon age ranges of A.D. 983-1051, 1082-1128 and 1135-1152.

These dates and the deposit elevation, requiring a discharge of $570,000 \mathrm{ft}^{3} / \mathrm{s}$, imply a second flood much larger than the 1867 flood in approximately the last 1,000 years. Such evidence is consistent with similar aged but lower deposits at the Looter Pit (app. 1) and Congo sites, although the approximately 1,000-year-old deposits at those sites could have been left by a smaller flood. Another possibility is again that of reworked charcoal and that the flood actually is younger, thus permitting correlation with the Red Flower flood. 


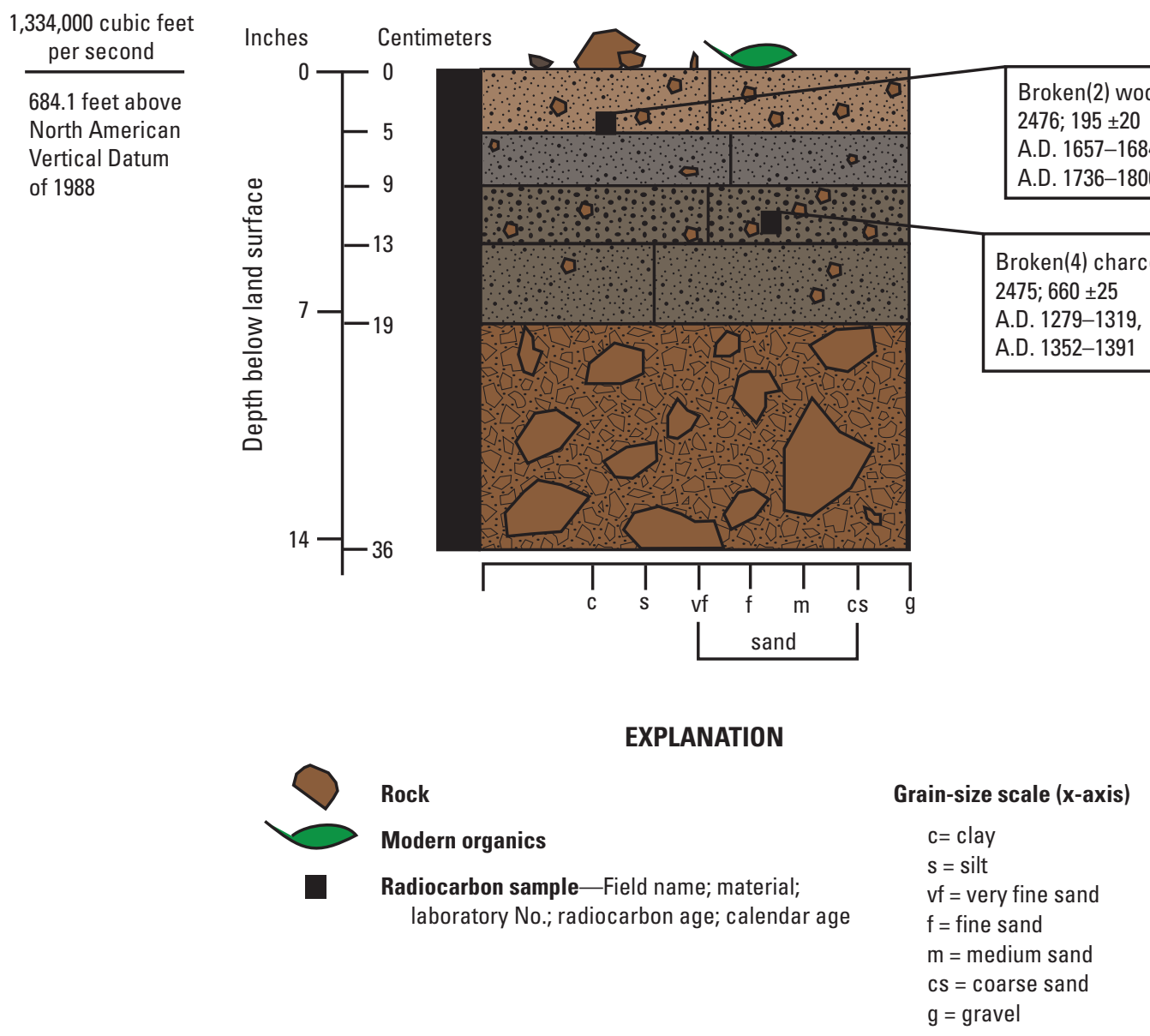

Figure 17. Schematic diagram showing the stratigraphy at the Broken Stem site, Tennessee River, Tennessee. 


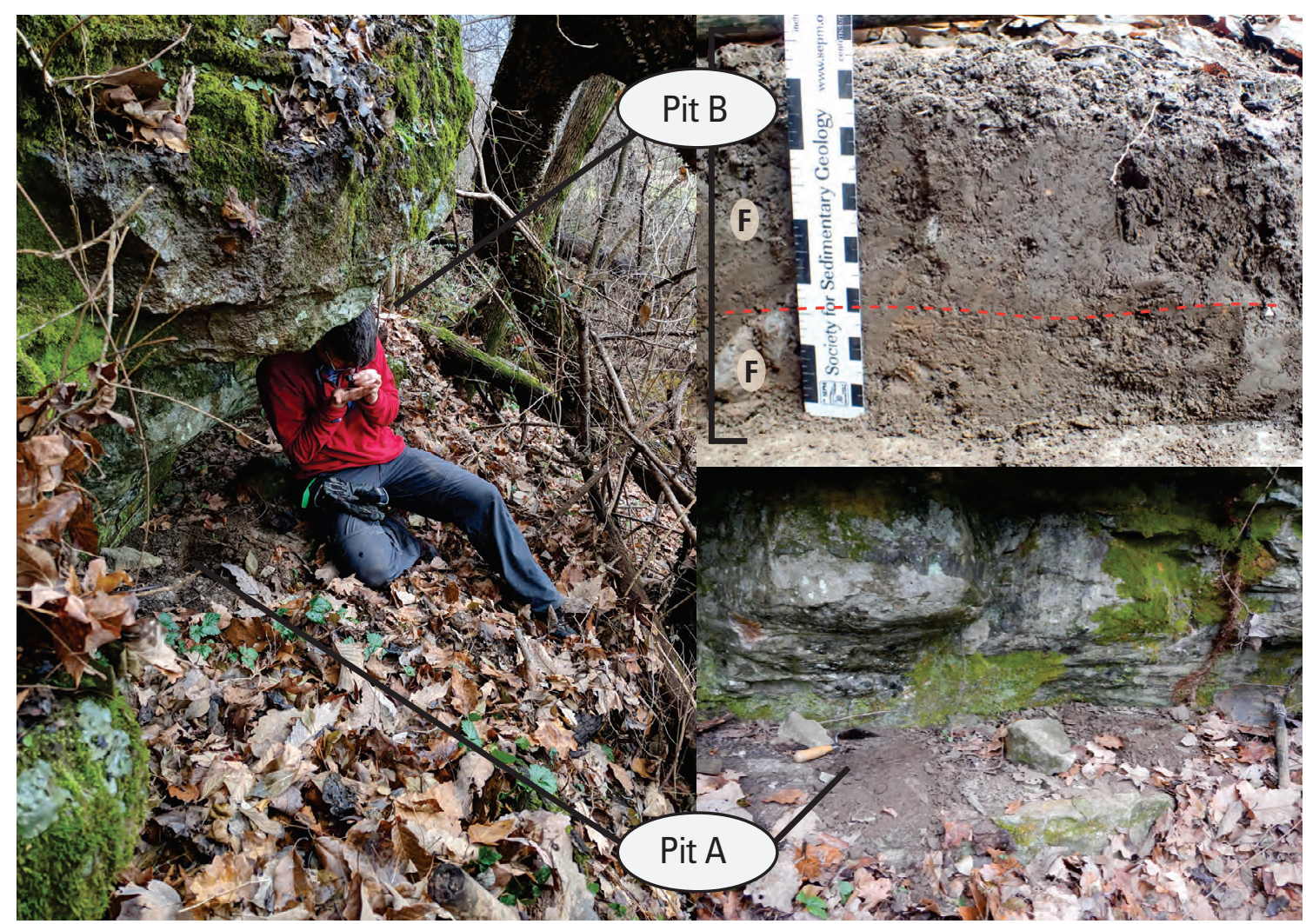

Figure 18. Location of pits $A$ and $B$ (left and lower right photographs) along the narrow bedrock ledge as well as the stratigraphy of pit B (upper right photograph), at the Last Survey site, Tennessee River, Tennessee. The stratigraphy in both pits was similar and contained evidence of two floods. " $F$ " indicates a flood deposit. 
416,000 cubic feet
per second

670.31 feet above North American

Vertical Datum of 1988

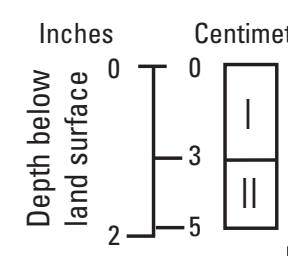

Pit A

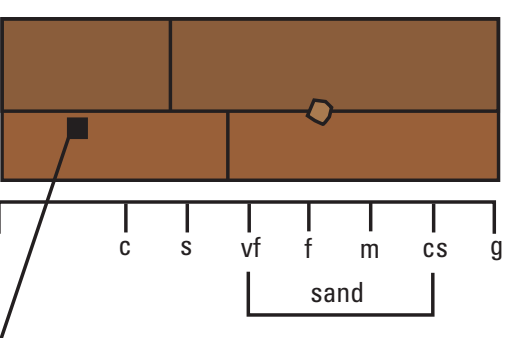

Last Survey(2); charcoal

489912; $250 \pm 40$

A.D. 1514-1600, 1616-1684, 1736-1805
1867 flood about 674 feet above North American

Vertical Datum of 1988

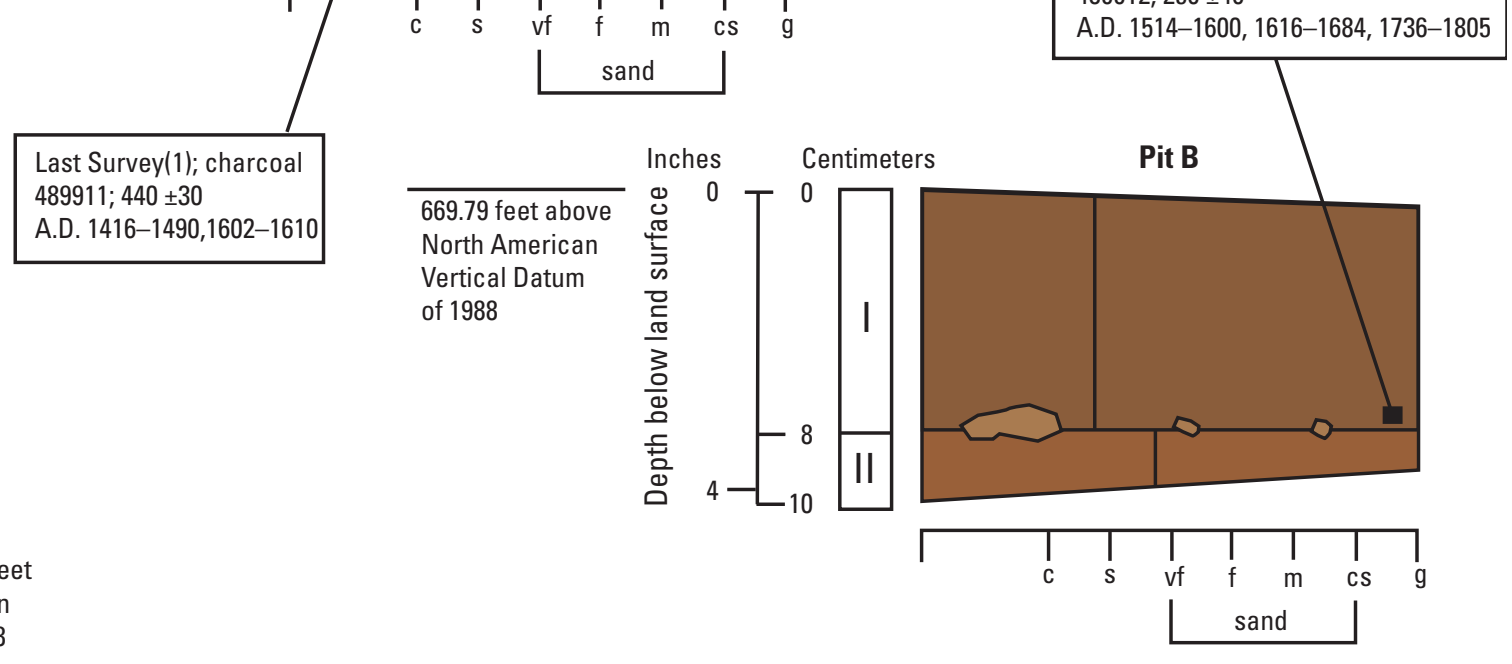

\section{EXPLANATION}

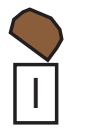

Rock

Tennessee River flood deposit

Radiocarbon sample-Field name; material; laboratory No.; radiocarbon age; calendar age

$$
\begin{aligned}
& \text { Grain-size scale (x-axis) } \\
& \mathrm{c}=\text { clay } \\
& \mathrm{s}=\text { silt } \\
& \text { vf }=\text { very fine sand } \\
& f=\text { fine sand } \\
& \mathrm{m}=\text { medium sand } \\
& \text { cs = coarse sand } \\
& \mathrm{g}=\text { gravel }
\end{aligned}
$$

Figure 19. Stratigraphy in pits A and B at the Last Survey site, Tennessee River, Tennessee. 


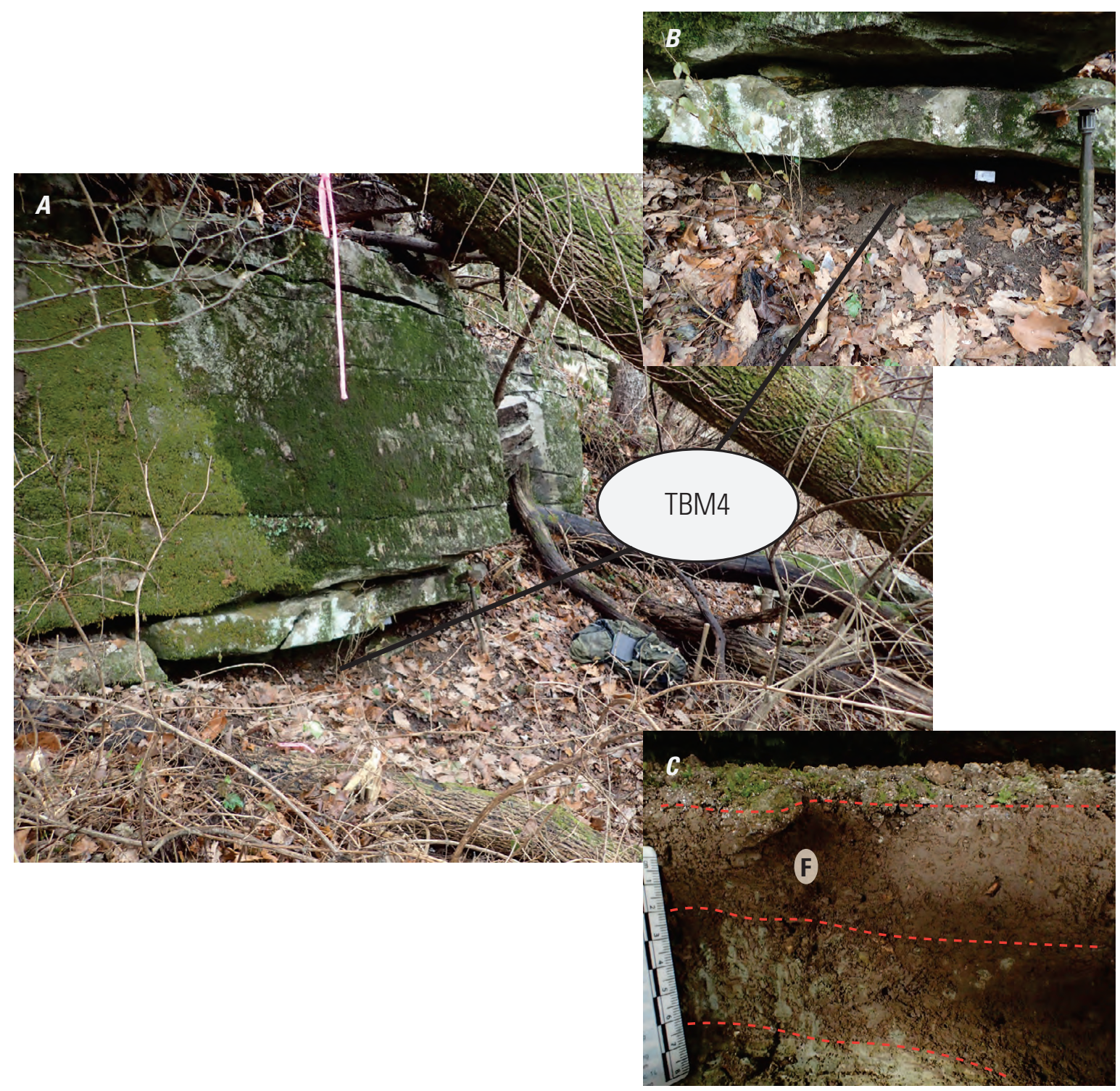

Figure 20. Location of the pit $(A$ and $B)$ and exposed stratigraphy in the pit $(C)$, at the TBM-4 site, Tennessee River, Tennessee. 


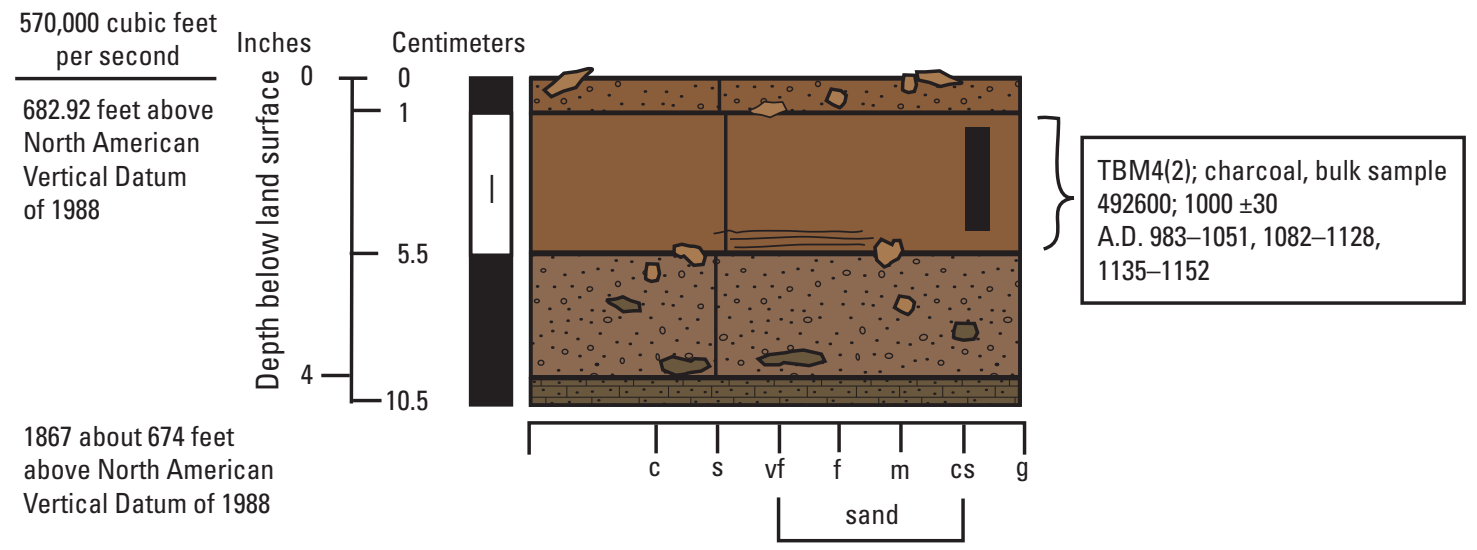

EXPLANATION

\begin{tabular}{lll} 
Rock & Grain-size scale (x-axis) \\
\hline Tennessee River flood deposit & $\mathrm{c}=$ clay \\
Radiocarbon sample_Field name; material; & $\mathrm{s}=$ silt \\
laboratory No.; radiocarbon age; calendar age & $\mathrm{vf}=$ very fine sand \\
& $\mathrm{f}=$ fine sand \\
& $\mathrm{m}=$ medium sand \\
& $\mathrm{cs}=$ coarse sand \\
& $\mathrm{g}=$ gravel
\end{tabular}

Figure 21. Stratigraphy at the TBM4 site, Tennessee River, Tennessee.

\section{Overall Paleoflood Chronology- Number, Magnitude, and Timing}

From the stratigraphy, radiocarbon and OSL dating, and hydraulic modeling from the 6 primary sites (collaborated and supplemented by the 11 additional sites), we infer at least 8 distinct prehistoric floods recorded by the paleoflood stratigraphy over the last 3,500-4,000 years in addition to the 1867 historical flood (table 4; fig. 22). This count results primarily from the four large floods identified at Jeff-n-Steph (P8, P3, P1, and the 1867 flood), the large flood dating to A.D. 983-1152 at Congo and possibly TBM4 (P4), the flood dating to the 1400s or 1500s at Last Survey (P7), and three flood deposits only recorded at the low-elevation Mud Wasp (P5, P6) and Looter Pit (P2) sites described in appendix 1. Additionally, a deposit inferred to have been left by the 1867 flood caps the sequence at several sites including Jeff-n-Steph. Another very young deposit, possibly from the 1875 historical flood, caps the stratigraphy at several low sites. This overall paleoflood chronology was inferred by correlating floods at each site with those of other sites based on the age of the deposits, elevation, and associated discharge estimates, as well as deposit characteristics such as texture and thickness.

As evidenced from the stratigraphic record and geochronology, several of the low-elevation sites have variable and incomplete records (fig. 22). Some sites, such as Last Survey and Oven, only have records going back a few hundred years. Other sites, such as Buzzard's Cave, Looter Pit, and Smirnoff, seem to have gaps of thousands of years, missing floods recorded at higher sections. These low sites probably are subject to episodic flood erosion, compromising their records.

The assigned discharge values for each paleoflood are based on the elevation of that paleoflood's highest inferred occurrence and the local stage-discharge relation determined from the hydraulic modeling. For example, deposits were correlated to the Red Flower flood at several sites (fig. 22) but the estimated discharge of $1,100,000 \mathrm{ft}^{3} / \mathrm{s}$ owes to the elevation of the flood at the Red Flower site, a value corroborated by its presence at Goose Wallow, also indicating a discharge of more than $1,000,000 \mathrm{ft}^{3} / \mathrm{s}$. Similarly, the elevations of the two older paleofloods (P3 and P1) at Jeff-n-Steph require discharges of at least $470,000 \mathrm{ft}^{3} / \mathrm{s}$.

The timing of the eight paleofloods is based on the geochronology and the inferred stratigraphic correlations. For many floods exact timing is poorly known or ambiguous, but a general sequence is defined by these findings:

- The total stratigraphic record extends back for $3,500-4,000$ years, as indicated by the basal ages at several sites, the dates of flood deposits at Williams Island, and the age of the colluvium and slope wash beneath the flood deposits at the Red Flower and Jeffn-Steph sites. 
Table 4. Eight individual paleofloods, the sites where the paleoflood deposits were found, the plausible dates on which they occurred (based on the ranges of possible radiocarbon and optically stimulated luminescence dates), and associated discharge estimates for each flood, Tennessee River, Tennessee.

[Discharge estimate: These discharge estimates from the hydraulic model are used in the flood-frequency analyses. However, in the report text, discharge estimates are reported using 2 significant figures to more accurately indicate the level of uncertainty. Abbreviation and symbols: $\mathrm{ft}^{3} / \mathrm{s}$, cubic feet per second; minus; +, plus; \%, percent]

\begin{tabular}{|c|c|c|c|c|c|}
\hline Paleoflood & Sites and flood unit number & Date & $\begin{array}{l}\text { Discharge } \\
\text { estimate } \\
\left(\mathrm{ft}^{3} / \mathrm{s}\right)\end{array}$ & $\begin{array}{l}\text { Minimum } \\
\text { discharge } \\
\left(-25 \% \text {, in } \mathrm{ft}^{3} / \mathrm{s}\right)\end{array}$ & $\begin{array}{l}\text { Maximum } \\
\text { discharge } \\
\left(+25 \% \text {, in } \mathrm{ft}^{3} / \mathrm{s}\right)\end{array}$ \\
\hline P1 & $\begin{array}{l}\text { Jeff-n-Steph IV, Smirnoff IV, Buzzard's Cave IV, Looter } \\
\text { Pit V, Turkey Blind III }\end{array}$ & 1300 B.C. & 470,000 & 352,000 & 588,000 \\
\hline 2 & Looter Pit IV & 1000 B.C. & 235,000 & 176,000 & 294,000 \\
\hline $\mathrm{P} 3^{1}$ & Jeff-n-Steph III, Turkey Blind III & A.D. 350 & 470,000 & 352,000 & 588,000 \\
\hline P5 & Mud Wasp VII & A.D. 1100 & 223,000 & 167,000 & 279,000 \\
\hline P6 & Mud Wasp V or VI & A.D. 1200 & 223,000 & 167,000 & 279,000 \\
\hline $\mathrm{P} 7^{1}$ & Oven III, Last Survey II, Mud Wasp IV & A.D. 1500 & 416,000 & 312,000 & 520,000 \\
\hline $\mathrm{P} 8^{1}$ & $\begin{array}{l}\text { Red Flower, Goose Wallow, TBM4², Jeff-n-Steph II, } \\
\text { Milled Wood I, Smirnoff VI, Freezer I, Upper Oven I, } \\
\text { Last Survey I, others }\end{array}$ & A.D. 1650 & $1,117,000$ & 838,000 & $1,396,000$ \\
\hline
\end{tabular}

${ }^{1}$ Floods used in the flood-frequency analyses.

${ }^{2}$ The flood deposit at the TBM4 site is either evidence of the same flood as P4 or P8 (most likely)

${ }^{3}$ If the TBM4 flood is the same as P4, the discharge estimate increases to $570,000 \mathrm{ft}^{3} / \mathrm{s}$ with a minimum discharge of $427,500 \mathrm{ft}^{3} / \mathrm{s}$ and a maximum discharge of $712,500 \mathrm{ft}^{3} / \mathrm{s}$.

- The Jeff-n-Steph site records four large floods of $470,000 \mathrm{ft}^{3} / \mathrm{s}$ or greater during approximately the last 3,500 years, three of which occurred since about A.D. 350.

- One large flood, the Red Flower flood (P8), occurred about A.D. 1650-1700, based on radiocarbon dating at the highest site at which its deposits were found, as well as similar ages at Goose Wallow, Jeff-n-Steph, and other sites (fig. 22).

- Three large floods preceded the Red Flower flood: (1) P7, approximately A.D. 1500 from dating at Last Survey and Oven; (2) P4, approximately A.D. 1000 from dating Congo and possibly TBM 4; and (3) P3, approximately A.D. 350 from radiocarbon dating at Jeff-n-Steph.

- Because of the inconsistent records among the low sites, we judge the record most complete only for those paleofloods with discharges (including hydraulic modeling uncertainty) greater than about $400,000 \mathrm{ft}^{3} / \mathrm{s}$ since the P3 flood at about A.D. 350. This includes four such floods: P3, P4, P7, and P8.

Partly because of the hazard implications of this finding, we sought confirmation at other sites. The Goose Wallow site, at nearly the same elevation as the Red Flower site, also had clear evidence of a Tennessee River flood. The similar ages obtained from flood deposits in various environments and elevations also corroborate the stratigraphic evidence at the Red Flower and Goose Wallow sites. A precise age for the flood is challenged by the variable ${ }^{14} \mathrm{C}$ calibration curve for the last several centuries, but the radiocarbon dating so far indicates that this flood must have occurred near or after about A.D. 1650. The lack of historical accounts for this immense flood means that it almost certainly occurred before first Euro-American settlement in Chattanooga area in the early 1800s. A similar-aged exceptional paleoflood was documented farther downstream on the Tennessee River by Davis and others (2019).

The Red Flower flood, although exceptionally large, seems consistent with regional and national records of large floods. The largest peak annual discharge from each of more than 22,000 USGS streamgages in the United States and Puerto Rico, arrayed by drainage basin area, is shown in figure 23 , modified from O'Connor and Costa (2003). The original figure has been augmented with an approximate limiting envelope curve bounding the data as well as the envelope curve proposed by Crippen and Bue (1977) for Region 5, which encompasses the Tennessee River Basin upstream from the study reach. The Red Flower flood plots slightly above the Region 5 envelope curve and near the top, but within, the maximum flood data for the United States and Puerto Rico. 


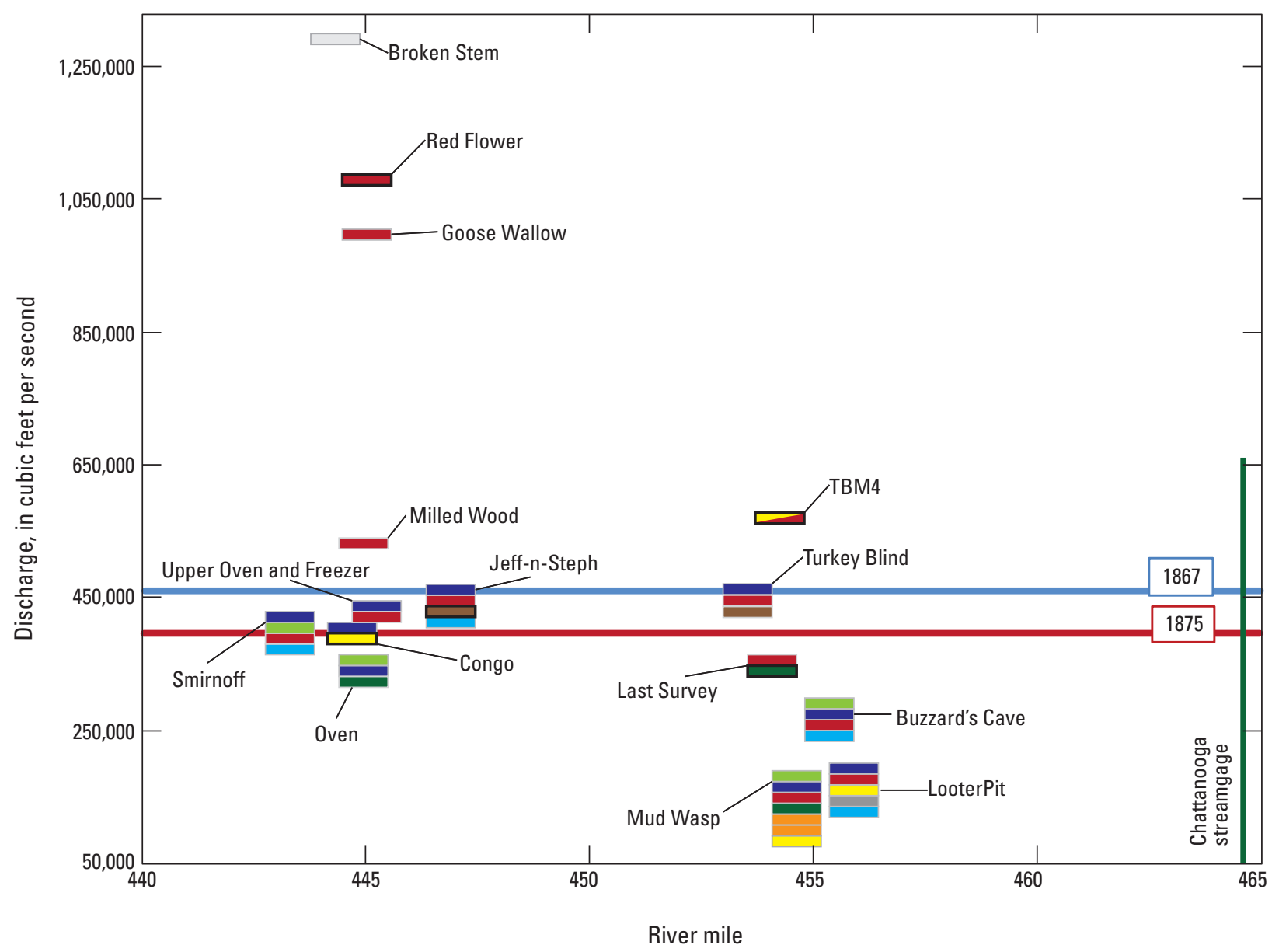

\section{EXPLANATION}

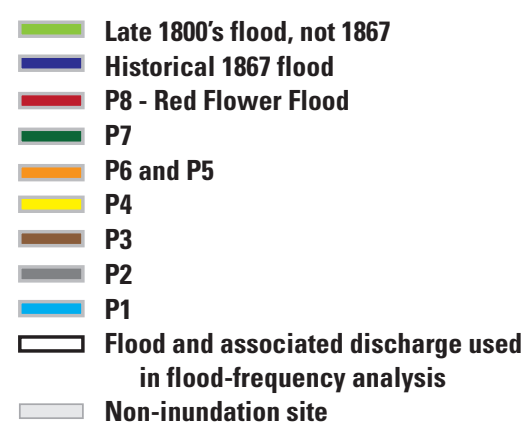

Figure 22. Floods in paleoflood sites (P1-P8), site relative to discharge required to inundate each site, number of flood deposits at each site, and relation of each flood to those at other sites (shown in colored boxes), Tennessee River, Tennessee. Black outline indicates which paleofloods were used in the flood-frequency analysis (table 4). 


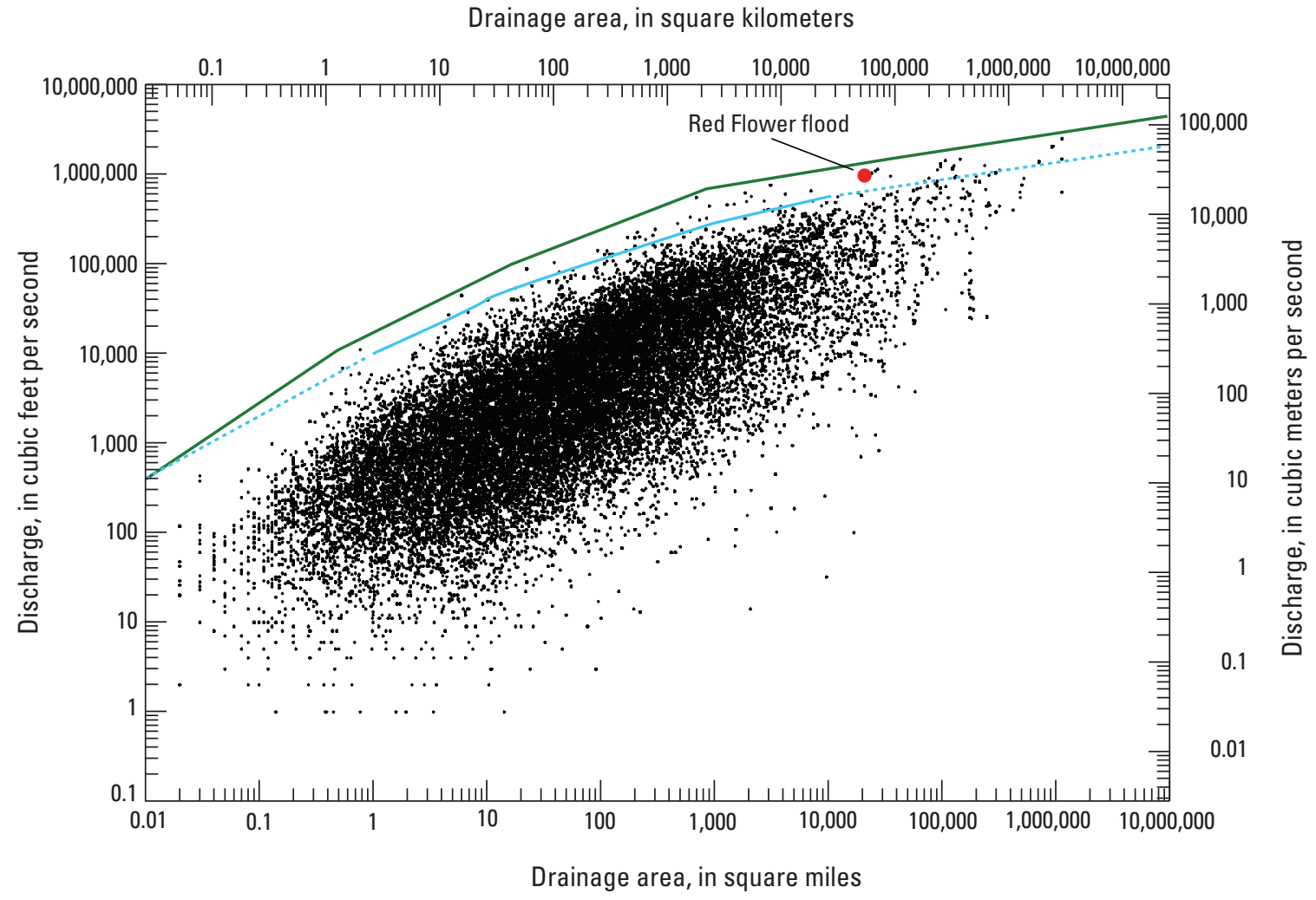

EXPLANATION

Region 5, dotted line is curve extended, from Crippen and Bue, 1977

National curve, modified from O'Connor and Costa, 2003

Figure 23. Largest peak annual discharge, arrayed by drainage basin, from more than 22,000 U.S. Geological Survey streamgages in the United States and Puerto Rico (modified from 0'Connor and Costa, 2003). Green (top) line indicates an approximate envelope curve bounding the highest flows in the United States. Blue (bottom) line is the envelope curve developed for Region 5 (Crippen and Bue, 1977), which encompasses the Tennessee River Basin upstream from the study area.

\section{Flood-Frequency Analysis}

For the flood-frequency analysis, the gaged, historical, and paleoflood information was structured into specific events and perception thresholds. These events and thresholds derive from the key findings are more precisely specified in the form of seven flood scenarios shown in tables 5 and 6 (Harden, 2021).

For this study, we defined several perception thresholds (table 5). Each perception threshold has an upper and lower bound. All upper bounds are set to infinity based on the assumption that no flood was too large to leave a record. The perception thresholds generally decrease with time as stratigraphic and historical records become more resolved. Therefore, the perception thresholds, if applied for an analysis, are progressively superseded as a lower one is implemented:
Table 5. Five perception thresholds used in the flood-frequency analyses, Tennessee River, Tennessee.

[Abbreviations and symbol: $\mathrm{ft}^{3} / \mathrm{s}$, cubic feet per second; PT, perception threshold; $\infty$, infinity]

\begin{tabular}{|c|c|c|}
\hline $\begin{array}{l}\text { Perception } \\
\text { threshold }\end{array}$ & Date range & $\begin{array}{c}\text { Discharge range } \\
\left(\mathrm{ft}^{3} / \mathrm{s}\right)\end{array}$ \\
\hline PT1 & 2000 B.C.-A.D. 349 & $838,000-\infty$ \\
\hline PT1A & 2000 B.C.-A.D. 349 & $1,117,000-\infty$ \\
\hline PT1B & 2000 B.C.-A.D. 349 & $1,396,000-\infty$ \\
\hline PT2 & A.D. $350-1825$ & $459,000-\infty$ \\
\hline PT3 & A.D. $1826-$ A.D. 1873 & $280,000-\infty$ \\
\hline PT4 & A.D. $1874-2008$ & $0-\infty$ \\
\hline PT5 & A.D. $1952-1952$ & $280,00-\infty$ \\
\hline
\end{tabular}


Table 6. Seven flood scenarios, including date of flood; sites where evidence was preserved; and estimated discharge median, minimum, and maximum, used in the flood-frequency analyses, Tennessee River, Tennessee.

[Abbreviations and symbol: PT, perception threshold; PX, paleoflood (from table 4); $\mathrm{ft}^{3} / \mathrm{s}$, cubic feet per second; \%, percent]

\begin{tabular}{|c|c|c|c|c|c|}
\hline \multirow{2}{*}{ Paleoflood } & \multirow{2}{*}{ Sites and flood unit number } & \multirow{2}{*}{$\begin{array}{c}\text { Approximate } \\
\text { date }\end{array}$} & \multicolumn{3}{|c|}{$\begin{array}{c}\text { Discharge } \\
\left(\mathrm{ft}^{3} / \mathrm{s}\right)\end{array}$} \\
\hline & & & Median & $\begin{array}{c}\text { Minimum } \\
(-25 \%)\end{array}$ & $\begin{array}{c}\text { Maximum } \\
(+25 \%)\end{array}$ \\
\hline \multicolumn{6}{|c|}{ Scenario 1-Historical and gaged record } \\
\hline \multicolumn{6}{|c|}{ Historical record (1826-73) plus Chattanooga streamgage record (1874-2008) + PT3-PT5 } \\
\hline \multicolumn{6}{|c|}{ Scenario 2-Four paleofloods + PT1-PT5 } \\
\hline P4 & Congo, Mud Wasp VI or V & A.D. 1000 & ${ }^{1} 459,000$ & ${ }^{1} 459,000$ & 500,000 \\
\hline P7 & Oven III, Last Survey II, Mud Wasp IV & A.D. 1500 & ${ }^{1} 459,000$ & ${ }^{1} 459,000$ & 520,000 \\
\hline P8 & $\begin{array}{l}\text { Red Flower, Goose Wallow, TBM4, Jeff- } \\
\text { n-Steph II, Milled Wood I, Smirnoff VI, } \\
\text { Freezer I, Upper Oven I, Last Survey I }\end{array}$ & A.D. 1650 & $1,117,000$ & 838,000 & $1,396,000$ \\
\hline P7 & Oven III, Last Survey II, Mud Wasp IV & A.D. 1500 & ${ }^{1} 459,000$ & ${ }^{1} 459,000$ & 520,000 \\
\hline P8 & $\begin{array}{l}\text { Red Flower, Goose Wallow, TBM4, Jeff- } \\
\text { n-Steph II, Milled Wood I, Smirnoff VI, } \\
\text { Freezer I, Upper Oven I, Last Survey I }\end{array}$ & A.D. 1650 & $1,117,000$ & 838,000 & $1,396,000$ \\
\hline \multicolumn{6}{|c|}{ Scenario 4-Four paleofloods + PT1B-PT5 } \\
\hline P3 & Jeff-n-Steph III & A.D. 350 & 470,000 & ${ }^{1} 459,000$ & 588,000 \\
\hline $\mathrm{P} 4$ & Congo, Mud Wasp VI or V & A.D. 1000 & ${ }^{1} 459,000$ & ${ }^{1} 459,000$ & 500,000 \\
\hline P7 & Oven III, Last Survey II, Mud Wasp IV & A.D. 1500 & ${ }^{1} 459,000$ & ${ }^{1} 459,000$ & 520,000 \\
\hline P8 & $\begin{array}{l}\text { Red Flower, Goose Wallow, TBM4, Jeff- } \\
\text { n-Steph II, Milled Wood I, Smirnoff VI, } \\
\text { Freezer I, Upper Oven I, Last Survey I }\end{array}$ & A.D. 1650 & $1,117,000$ & 838,000 & $1,396,000$ \\
\hline P8 & $\begin{array}{l}\text { Red Flower, Goose Wallow, TBM4, Jeff- } \\
\text { n-Steph II, Milled Wood I, Smirnoff VI, } \\
\text { Freezer I, Upper Oven I, Last Survey I }\end{array}$ & A.D. 1050 & $1,117,000$ & 838,000 & $1,396,000$ \\
\hline \multicolumn{6}{|c|}{ Scenario 6-Four paleofloods + PT1A-PT5; discharge of A.D. 1000 flood increased to the discharge of TBM4 } \\
\hline P3 & Jeff-n-Steph III & A.D. 350 & 470,000 & ${ }^{1} 459,000$ & 588,000 \\
\hline P4 & Congo, Mud Wasp VI or V, TBM4 & A.D. 1000 & 570,000 & ${ }^{1} 459,000$ & 712,500 \\
\hline P7 & Oven III, Last Survey II, Mud Wasp IV & A.D. 1500 & ${ }^{1} 459,000$ & ${ }^{1} 459,000$ & 520,000 \\
\hline P8 & $\begin{array}{l}\text { Red Flower, Goose Wallow, Jeff-n-Steph II, } \\
\text { Milled Wood I, Smirnoff VI, Freezer I, } \\
\text { Upper Oven I, Last Survey I }\end{array}$ & A.D. 1650 & $1,117,000$ & 838,000 & $1,396,000$ \\
\hline \multicolumn{6}{|c|}{ Scenario 7-Four paleofloods + PT1A-PT5; Red Flower flood discharge reduced to that of a flood at Jeff-n-Steph } \\
\hline P3 & Jeff-n-Steph III & A.D. 350 & 470,000 & ${ }^{1} 459,000$ & 588,000 \\
\hline P4 & Congo, Mud Wasp VI or V & A.D. 1000 & ${ }^{1} 459,000$ & ${ }^{1} 459,000$ & 500,000 \\
\hline P7 & Oven III, Last Survey II, Mud Wasp IV & A.D. 1500 & ${ }^{1} 459,000$ & ${ }^{1} 459,000$ & 520,000 \\
\hline
\end{tabular}


Table 6. Seven flood scenarios, including date of flood; sites where evidence was preserved; and estimated discharge median, minimum, and maximum, used in the flood-frequency analyses, Tennessee River, Tennessee.—Continued

[Abbreviations and symbol: PT, perception threshold; PX, paleoflood (from table 4); $\mathrm{ft}^{3} / \mathrm{s}$, cubic feet per second; \%, percent]

\begin{tabular}{|c|c|c|c|c|c|}
\hline \multirow{2}{*}{ Paleoflood } & \multirow{2}{*}{ Sites and flood unit number } & \multirow{2}{*}{$\begin{array}{l}\text { Approximate } \\
\text { date }\end{array}$} & \multicolumn{3}{|c|}{$\begin{array}{c}\text { Discharge } \\
\left(\mathrm{ft}^{3} / \mathrm{s}\right)\end{array}$} \\
\hline & & & Median & $\begin{array}{c}\text { Minimum } \\
(-25 \%)\end{array}$ & $\begin{array}{c}\text { Maximum } \\
(+25 \%)\end{array}$ \\
\hline \multicolumn{6}{|c|}{ Scenario 7-Four paleofloods + PT1A-PT5; Red Flower flood discharge reduced to that of a flood at Jeff-n-Steph-Continued } \\
\hline P8 & $\begin{array}{c}\text { Red Flower, Goose Wallow, TBM4, Jeff- } \\
\text { n-Steph II, Milled Wood I, Smirnoff VI, } \\
\text { Freezer I, Upper Oven I, Last Survey I }\end{array}$ & A.D. 1650 & 470,000 & ${ }^{1} 459,000$ & 588,000 \\
\hline
\end{tabular}

${ }^{1}$ Discharge is equal to lower bound of perception threshold.

- Perception thresholds $1,1 A$, and $1 B(P T 1,1 A$ and 1B) - These perception thresholds assume that all floods of the size of the Red Flower flood are recorded in a paleoflood record extending back 4,000 years (to 2000 B.C.). The three variants (PT1, PT1A, PT1B) use the low, median, and high discharge values, respectively, for the elevation of the Red Flower site, based on uncertainty in the hydraulic modeling. These variants distinguish flood-frequency scenarios 2,3 , and 4 (table 6).

- Perception threshold 2 (PT2)-This perception threshold is based on our judgment that the stratigraphic record is complete for floods larger than $459,000 \mathrm{ft}^{3} / \mathrm{s}$ since about A.D. 350, based on the number of sites, their elevations, correlations among deposits, and their ages. PT2 is used in flood scenarios 2-7.

- Perception threshold 3 (PT3) - The historical stage records for the 1826, 1847, and 1867 floods indicate that all floods greater than about $280,000 \mathrm{ft}^{3} / \mathrm{s}$ would have been recorded in the 1826-73 pre-streamgage historical record. PT3 is used in all flood scenarios.

- Perception threshold 4 (PT4) —Since the 1874 establishment of the Chattanooga streamgage, all annual peak discharges, regardless of magnitude, have been recorded except for 1952. A perception threshold with the lower bound of zero is set for PT4, which is used in all flood scenarios.

- Perception threshold 5 (PT5)—Because the 1952 flood peak is missing in the gaged record, this year-long perception threshold was set to the historical perception threshold of $280,000 \mathrm{ft}^{3} / \mathrm{s}$. PT5 is used in all flood scenarios.

The seven flood scenarios represent different treatments of the flood observations (in reference to the perception thresholds) implemented to (1) determine the effects of adding paleoflood data to flood-frequency analysis for the Tennessee River and (2) to evaluate the effects of uncertainties in the paleoflood record for the resulting flood-frequency estimates.

Scenario 1 (table 6) incorporates only the gaged and historical flow peaks and excludes the paleoflood information. It provides a baseline from which to evaluate the effects of incorporating paleoflood information in the analysis. For the gaged and historical floods, the dates and magnitudes were assumed to be precise and as reported. This scenario uses three perception thresholds (table 6; fig. 24):

- For the historical period preceding installation of the streamgage at Chattanooga, we assume a perception threshold (PT3) of $280,000 \mathrm{ft}^{3} / \mathrm{s}$ for the period A.D 1826-1873. This time period is based on the historical accounts of large floods beginning with the 1826 flood that we estimate had a discharge of about 280,000 $\mathrm{ft}^{3} / \mathrm{s}$. We assume that all flows of that discharge and greater would be recorded prior to the 1874 streamgage installation.

- For the period of gaged flow from 1874 to 2008 all annual peaks are recorded, except in 1952; hence, we apply the perception threshold of $0 \mathrm{ft}^{3} / \mathrm{s}$ (PT4).

- For the single year of 1952 for which there is no gaged record of peak flow, we assume that the peak was less than the historically noteworthy peaks of greater than $280,000 \mathrm{ft}^{3} / \mathrm{s}$ (PT5).

The other six scenarios incorporate paleoflood information in addition to the gaged and historical records (table 6 and fig. 25). The six paleoflood scenarios each involve four paleofloods larger than $459,000 \mathrm{ft}^{3} / \mathrm{s}$ since about A.D. 350 and, in different combination, perception thresholds $1,1 \mathrm{~A}, 1 \mathrm{~B}$, and 2 (table 5).

The specified discharge for each paleoflood included in the analysis was the discharge required to attain the deposit elevation, assigning \pm 25 percent uncertainty to account for uncertainty in the hydraulic model and channel changes 


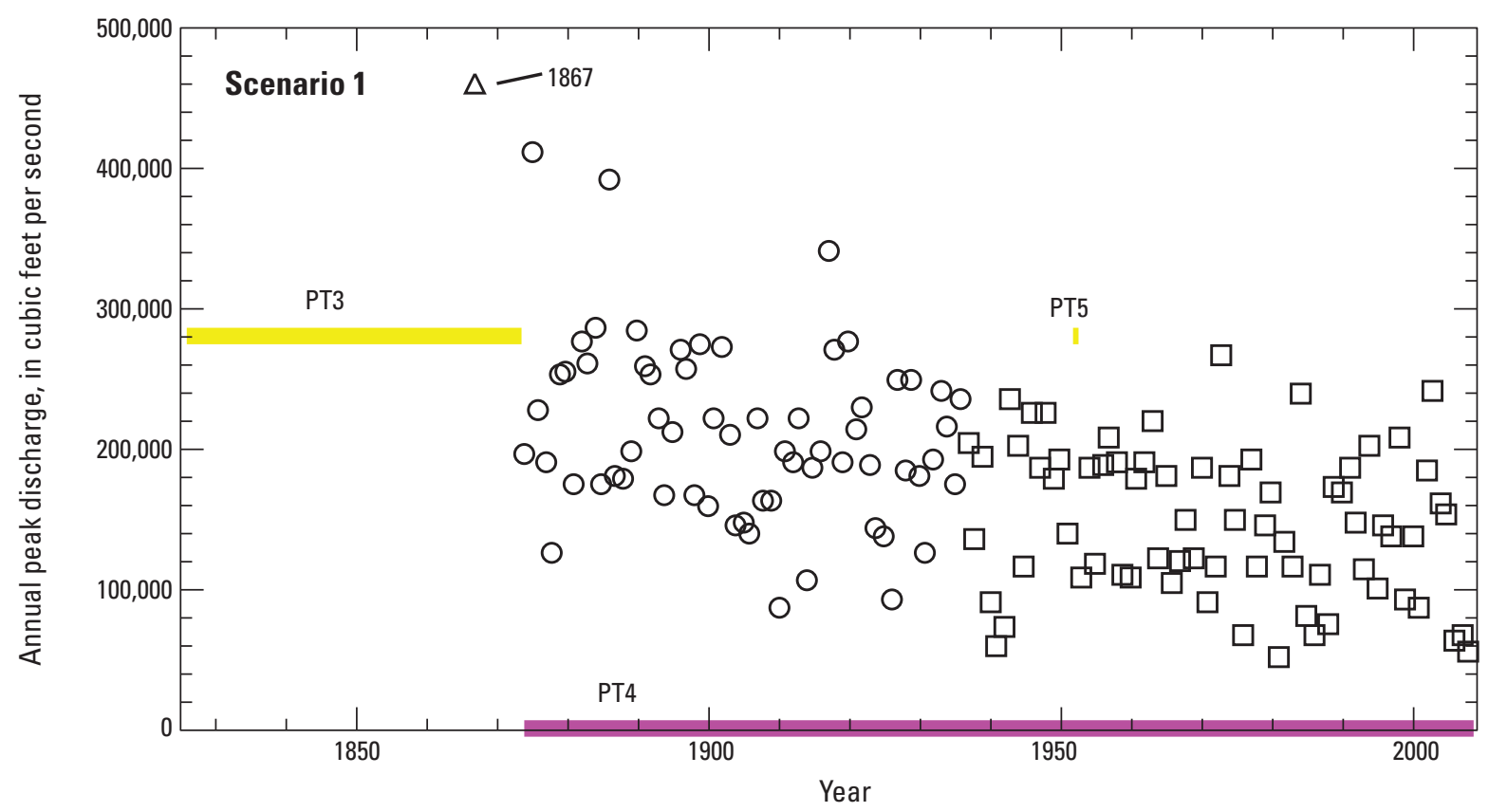

EXPLANATION

$\triangle$ Historical peak discharge

O Gaged peak discharge

Urban or regulated peaks

Note: Horizontal bars represent perception thresholds for the gaged and historical record

Figure 24. Gaged and historical data included in the gaged plus historical flood-frequency analysis (scenario 1) of the Tennessee River, Tennessee. Perception thresholds (PT3 and PT4) are described in table 5 and Scenario 1 is described in table 6.

(including Manning's $n$ values) that might have occurred from the time the flood occurred to the present. If the lower range of the flood discharge estimate was below a perception threshold, the threshold value was used as the minimum discharge estimate for the recorded flood (table 6). The flood dates incorporated in the analysis are single-value estimates based on the geochronology (table 4) because PeakFQ (Veilleux and others, 2014), the flood frequency software used in this study, does not permit age ranges to be specified.

The dates and magnitudes for each of the paleofloods are as specified in tables 4 and 6, except where modified as follows, to test the effects of uncertainty in the resulting floodfrequency assessments:

- Scenarios 2, 3, and 4 test uncertainty in the hydraulic modeling and plausible effect to the discharge threshold for the Red Flower site and its associated perception threshold, as specified for PT1, PT1A, and PT1B. Scenario 3, based on the best estimate for the stagedischarge relation at the Red Flower site (PT1A) and our preferred overall interpretation of the paleoflood record, is our overall preferred scenario for estimating flood-frequency.
- Scenario 5 tests, relative to Scenario 3, the effects of the possibility that the Red Flower flood is older than about A.D. 1650 and instead dates to about A.D. 1050, consistent with the age of the possibly correlative deposit at TMB4.

- Scenario 6 incorporates the interpretation that the flood dating to about A.D. 1000 at TBM4 is distinct from the Red Flower flood, thus implying a discharge of $570,000 \mathrm{ft}^{3} / \mathrm{s}$ rather than the $459,000 \mathrm{ft}^{3} / \mathrm{s}$ (as in Scenario 3) for the lower-elevation-correlated deposit the Congo site.

- Scenario 7 addresses the possibility that our interpretation of a Tennessee River flood genesis for the deposits is incorrect for the high Red Flower and Goose Wallow sites and that, instead, the largest paleoflood discharges are indicated by the elevations of the Jeff-n-Steph deposits.

Conventional flood-frequency analysis would account for the gaged record and possibly historical records. The flood-frequency curve resulting from application of the Bulletin 17C guidelines (England and others, 2018) is shown in figure 26 as implemented by the PeakFQ software 

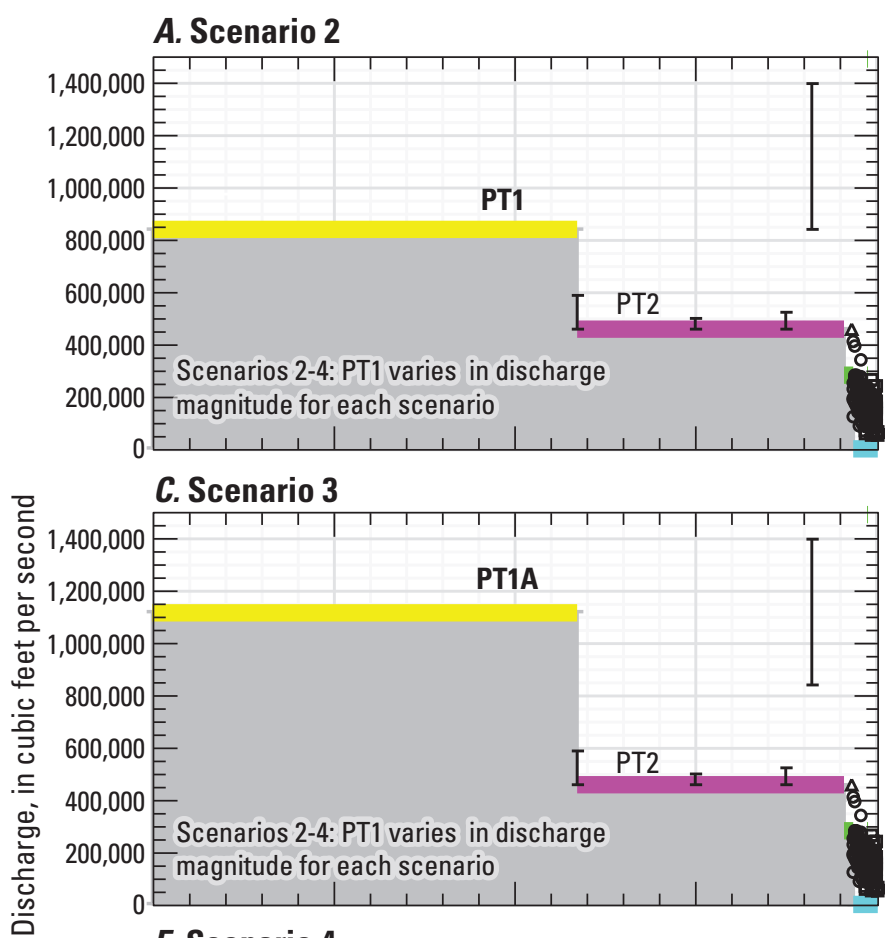

E. Scenario 4

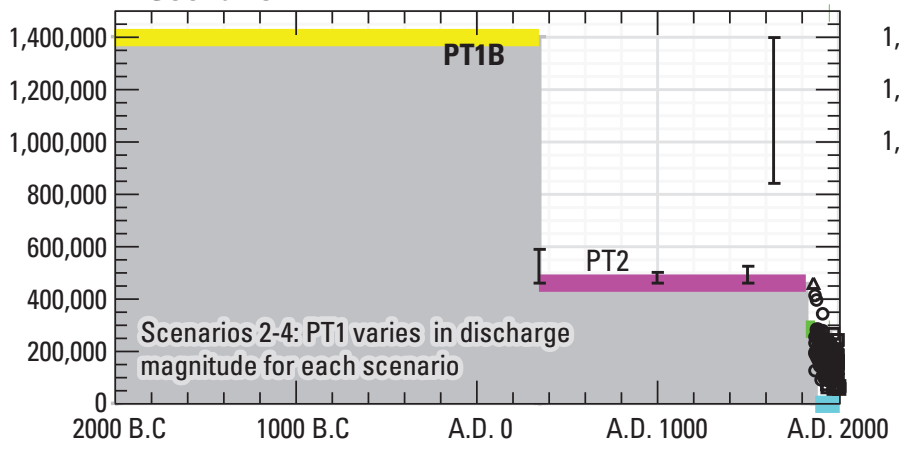

\section{B. Scenario 5}
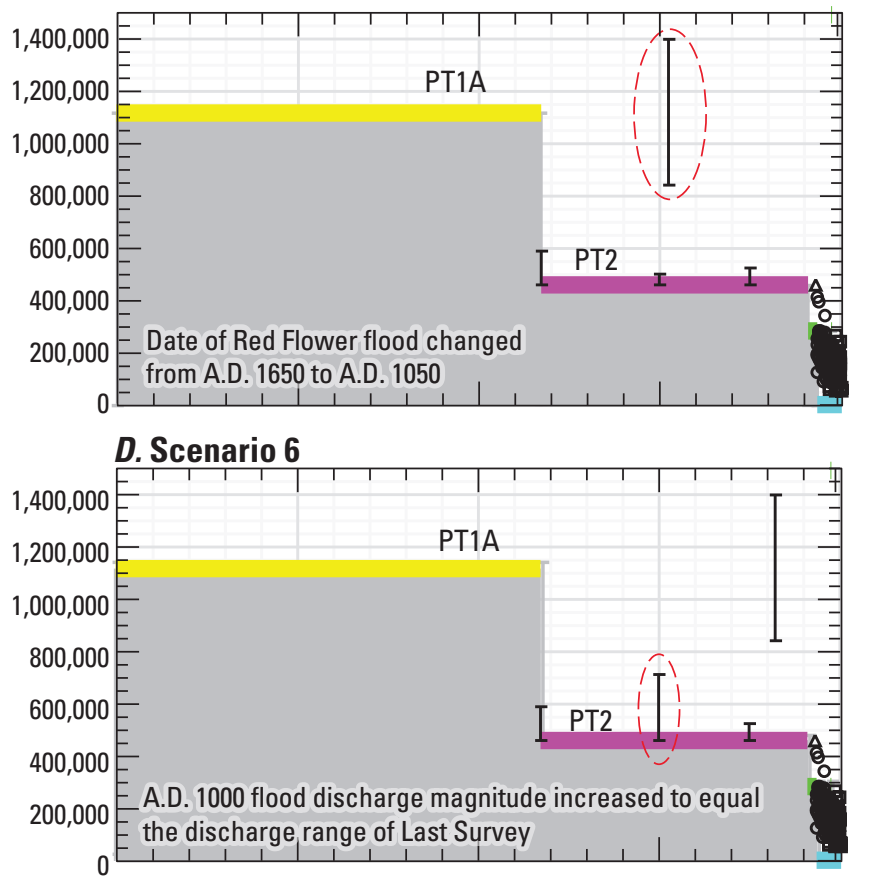

F. Scenario 7

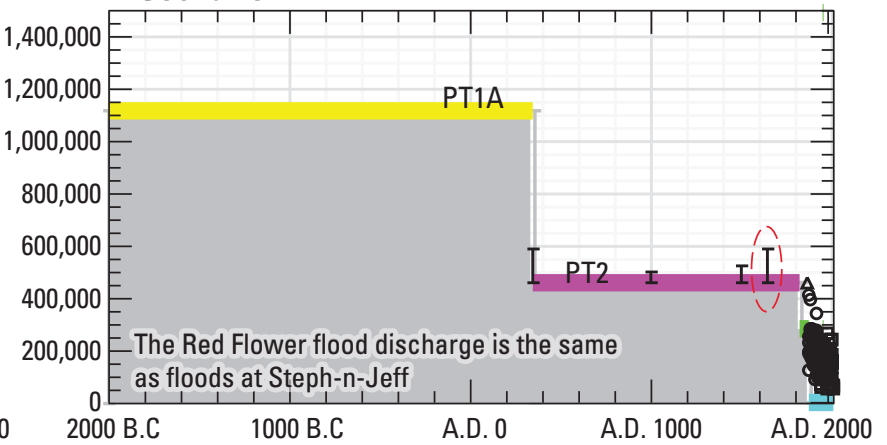

Date, B.C. or A.D.

\title{
EXPLANATION
}

\author{
I $\quad 95-p e r c e n t$ confidence limit
}

Note: Horizontal bars represent perception thresholds for each scenario

Figure 25. Gaged, historical, and paleoflood data and associated perception thresholds included in scenarios 2-7, Tennessee River, Tennessee. In scenarios 2-4, the magnitude of the perception thresholds varied (as shown in bold) based on the estimated discharge of the Red Flower flood. In scenarios 5-7, the magnitude and timing of the paleofloods varied (as indicated by the ovals) based on uncertainties in the stratigraphy and geochronology. Because of the scale of the figure, the gaged plus historical record (1826-2008) is better viewed in figure 24. Perception thresholds (PTX) are described in table 5 and scenarios are described in table 6.

(Veilleux and others, 2014) for the Tennessee River streamgage at Chattanooga for gaged peaks from 1874 to 2008 and including the 1867 historical peak as specified in scenario 1 (table 6 and fig. 24). This provides baseline results from which to compare the analyses incorporating the paleoflood information from the six other scenarios. The analysis of scenario 1 shows the 1867 flood with an AEP of about 0.001, estimated by where the flood discharge estimate $(459,000$ $\mathrm{ft}^{3} / \mathrm{s}$ ) intersects with the fitted frequency curve (fig. 26). Considering the 95-percent confidence intervals (CIs), the actual AEP spans nearly three orders of magnitude between about 0.08 and 0.0001 . 


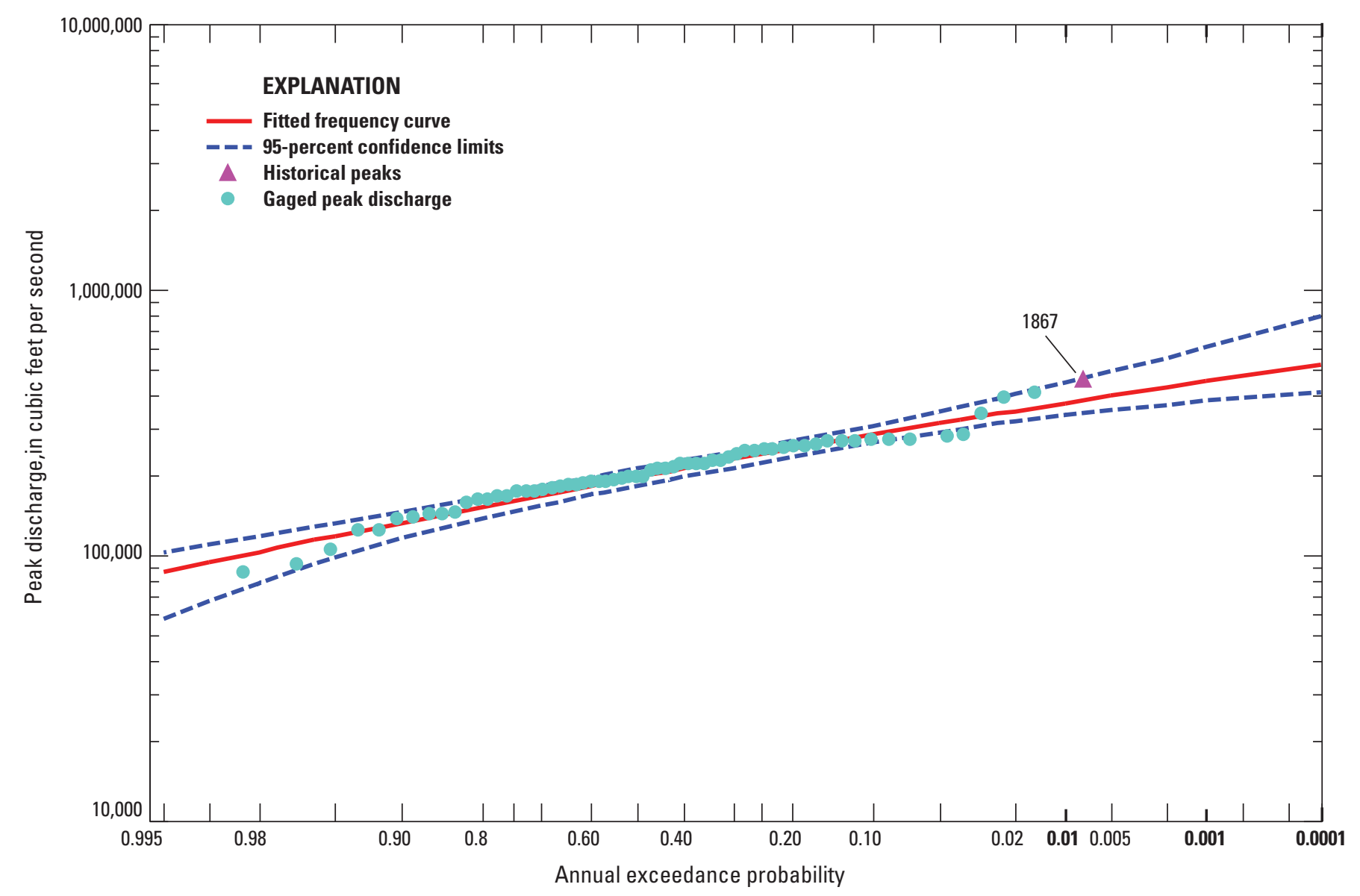

Figure 26. Flood-frequency analysis including all gaged and historical flood data (scenario 1), Tennessee River, Tennessee. The 0.01, 0.001 , and 0.0001 annual exceedance probability flood quantiles are labeled in bold on the $x$-axis.

Flood-frequency analyses for all paleoflood scenarios indicate that the addition of paleoflood information increases the quantile estimates for low-probability floods (table 7). For example, our preferred paleoflood interpretation represented by scenario 3 (fig. 27) gives an estimate for the 1,000 -year quantile flow of $540,000 \mathrm{ft}^{3} / \mathrm{s}$, about 17 percent greater than the $450,000 \mathrm{ft}^{3} / \mathrm{s}$ resulting from assessment of the gaged record and historical record (scenario 1; table 7). The other paleoflood scenarios $(2,4,5,6$, and 7$)$ give 1,000-year quantile estimates ranging from $490,000 \mathrm{ft}^{3} / \mathrm{s}$ to $540,000 \mathrm{ft}^{3} / \mathrm{s}$ (figs. 28 and 29). From comparison of scenarios 1, 3, and 7 (which discounts the high Red Flower deposits), it is evident that the increase is the consequence of including information for the large Red Flower flood. Evidence for this flood is thus a critical interpretation and key contribution to understanding flood frequency for the Tennessee River near Chattanooga, Tennessee.

Neither the timing of individual paleofloods (comparing scenarios 3 and 5) nor the correlation uncertainties (comparing scenarios 3 and 6 ) have substantial effect on the quantile estimates (fig. 28). Lowering the value of the Red Flower flood to a discharge equal to the second oldest flood at Jeffn-Steph substantially reduces the discharge estimates for all flood quantiles compared to the other paleoflood scenarios (scenario 7; figs. 28 and 29; table 7).

Another important effect of incorporating the paleoflood information is the substantial reduction in the uncertainty of the flood quantile estimates shown by the narrowing of the 95-percent confidence limits (fig. 29; table 7). For example, the confidence limits for the 1,000-year quantile estimate using the four paleofloods as adopted in scenario 3 are $480,000-620,000 \mathrm{ft}^{3} / \mathrm{s}$ compared to $380,000-610,000 \mathrm{ft}^{3} / \mathrm{s}$ for the gaged plus historical record (fig. 29), a reduction in the 95 -percent CIs by 38 percent. Similarly, uncertainty-as measured as the difference between the upper and lower 95-percent confidence limits - for all flood quantile estimates from 100 to 10,000 years was reduced by $22-44$ percent compared to using only the gaged and historical flood information as analyzed for scenario 1 (figs. 28 and 29; table 7). 
Table 7. Flood-frequency results of five flood quantiles (0.01-0.0001 annual exceedance probability) for scenarios 1-7, Tennessee River, Tennessee.

[Results include EMA estimate ("fitted flood-frequency curve" on figs. 26-28) and lower and upper bounds of the 95-percent confidence limits. The additional 4,000 years of paleoflood data raise the flood quantile magnitude and reduce the uncertainty in the confidence limits in scenarios 2-7. Abbreviations: AEP, annual exceedance probability; EMA, expected moments algorithm; AEP, annual exceedance probability; PT, perception threshold; $\mathrm{ft}^{3} / \mathrm{s}$, cubic feet per second]

\begin{tabular}{|c|c|c|c|c|}
\hline \multirow{2}{*}{$\begin{array}{l}\text { Return } \\
\text { period } \\
\text { (years) }\end{array}$} & \multirow{2}{*}{ AEP } & \multirow{2}{*}{$\begin{array}{c}\text { EMA } \\
\text { estimate } \\
\left(\mathrm{ft}^{3} / \mathrm{s}\right)\end{array}$} & \multicolumn{2}{|c|}{$\begin{array}{c}\text { 95-percent } \\
\text { confidence limits }\end{array}$} \\
\hline & & & Lower & Upper \\
\hline \multicolumn{5}{|c|}{ Scenario 1-Historical and gaged record } \\
\hline 100 & 0.01 & 370,000 & 340,000 & 450,000 \\
\hline 200 & 0.005 & 390,000 & 350,000 & 490,000 \\
\hline 500 & 0.002 & 430,000 & 370,000 & 560,000 \\
\hline 1,000 & 0.001 & 450,000 & 380,000 & 660,000 \\
\hline 10,000 & 0.0001 & 520,000 & 410,000 & 800,000 \\
\hline \multicolumn{5}{|c|}{ Scenario 2-Four paleofloods, PT1-PT5 } \\
\hline 100 & 0.01 & 400,000 & 370,000 & 430,000 \\
\hline 200 & 0.005 & 440,000 & 400,000 & 480,000 \\
\hline 500 & 0.002 & 500,000 & 450,000 & 550,000 \\
\hline 1,000 & 0.001 & 540,000 & 480,000 & 610,000 \\
\hline 10,000 & 0.0001 & 700,000 & 600,000 & 880,000 \\
\hline \multicolumn{5}{|c|}{ Scenario 3-Four paleofloods, PT1A-PT5, best estimate } \\
\hline 100 & 0.01 & 400,000 & 370,000 & 430,000 \\
\hline 200 & 0.005 & 440,000 & 400,000 & 480,000 \\
\hline 500 & 0.002 & 500,000 & 450,000 & 560,000 \\
\hline 1,000 & 0.001 & 540,000 & 490,000 & 620,000 \\
\hline 10,000 & 0.0001 & 700,000 & 600,000 & 900,000 \\
\hline \multicolumn{5}{|c|}{ Scenario 4-Four paleofloods, PT1B-PT5 } \\
\hline 100 & 0.01 & 400,000 & 370,000 & 430,000 \\
\hline 200 & 0.005 & 440,000 & 400,000 & 480,000 \\
\hline 500 & 0.002 & 500,000 & 450,000 & 560,000 \\
\hline 1,000 & 0.001 & 540,000 & 480,000 & 620,000 \\
\hline 10,000 & 0.0001 & 700,000 & 600,000 & 900,000 \\
\hline \multicolumn{5}{|c|}{ Scenario 5-Four paleofloods (Red Flower A.D. 1050), PT1A-PT5 } \\
\hline 100 & 0.01 & 400,000 & 370,000 & 430,000 \\
\hline 200 & 0.005 & 440,000 & 400,000 & 480,000 \\
\hline 500 & 0.002 & 490,000 & 450,000 & 560,000 \\
\hline 1,000 & 0.001 & 540,000 & 480,000 & 620,000 \\
\hline 10,000 & 0.0001 & 700,000 & 600,000 & 900,000 \\
\hline \multicolumn{5}{|c|}{ Scenario 6-Four paleofloods (TMB discharge used for A.D 1000 flood), PT1A-PT5 } \\
\hline 100 & 0.01 & 400,000 & 370,000 & 440,000 \\
\hline 200 & 0.005 & 440,000 & 410,000 & 480,000 \\
\hline 500 & 0.002 & 500,000 & 450,000 & 560,000 \\
\hline 1,000 & 0.001 & 540,000 & 490,000 & 630,000 \\
\hline 10,000 & 0.0001 & 710,000 & 600,000 & 920,000 \\
\hline
\end{tabular}


Table 7. Flood-frequency results of five flood quantiles (0.01-0.0001 annual exceedance probability) for scenarios 1-7, Tennessee River, Tennessee.-Continued

[Results include EMA estimate ("fitted flood-frequency curve" on figs. 26-28) and lower and upper bounds of the 95 -percent confidence limits. The additional 4,000 years of paleoflood data raise the flood quantile magnitude and reduce the uncertainty in the confidence limits in scenarios 2-7. Abbreviations: AEP, annual exceedance probability; EMA, expected moments algorithm; AEP, annual exceedance probability; PT, perception threshold; $\mathrm{ft}^{3} / \mathrm{s}$, cubic feet per second]

\begin{tabular}{|c|c|c|c|c|}
\hline \multirow{2}{*}{$\begin{array}{l}\text { Return } \\
\text { period } \\
\text { (years) }\end{array}$} & \multirow[t]{2}{*}{ AEP } & \multirow{2}{*}{$\begin{array}{c}\text { EMA } \\
\text { estimate } \\
\left(\mathrm{ft}^{3} / \mathrm{s}\right)\end{array}$} & \multicolumn{2}{|c|}{$\begin{array}{c}\text { 95-percent } \\
\text { confidence limits }\end{array}$} \\
\hline & & & Lower & Upper \\
\hline \multicolumn{5}{|c|}{ Scenario 7-Four paleofloods (Red Flower flood discharge equal to that of Jeff-n-Steph flood), PT1A- PT5 } \\
\hline 100 & 0.01 & 390,000 & 360,000 & 420,000 \\
\hline 200 & 0.005 & 420,000 & 390,000 & 450,000 \\
\hline 500 & 0.002 & 460,000 & 420,000 & 500,000 \\
\hline 1,000 & 0.001 & 490,000 & 440,000 & 540,000 \\
\hline 10,000 & 0.0001 & 580,000 & 510,000 & 690,000 \\
\hline
\end{tabular}

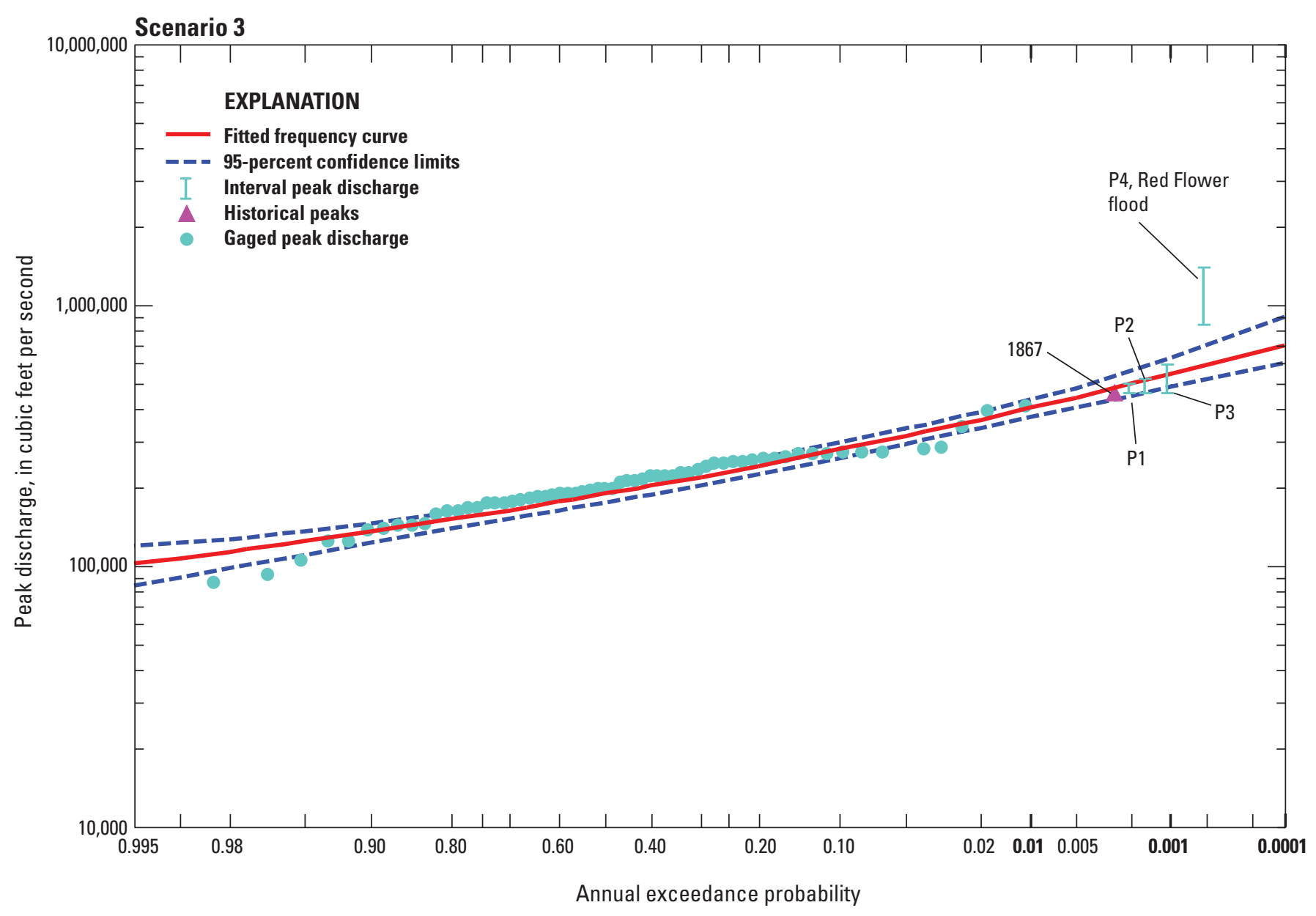

Figure 27. Flood-frequency analysis including all gaged data, the 1867 historical flood and four paleofloods (scenario 3), Tennessee River, Tennessee. The $0.01,0.001$, and 0.0001 flood quantiles are labeled in bold on the $x$-axis. 


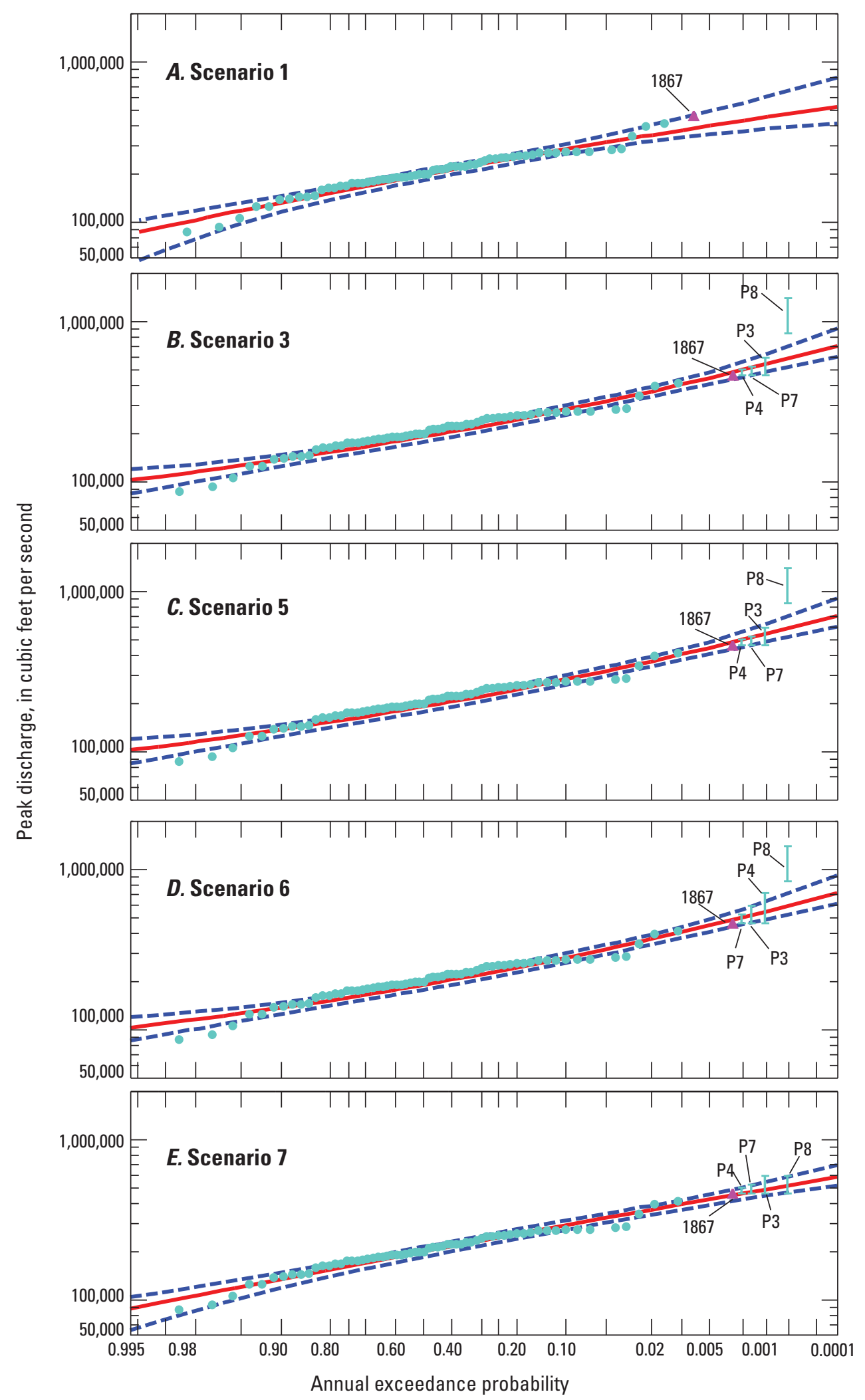

\section{EXPLANATION}

Fitted frequency curve

- - 95-percent confidence limits Interval peak discharge

- Historical peaks

- Gaged peak discharge

Figure 28. Selected flood-frequency analysis curves including all gaged data, the 1867 historical flood, and four paleofloods (scenarios 1, 3, and 5-7), Tennessee River, Tennessee. Graphs have been scaled to highlight the curves from 100,000 to 1,000,000 cubic feet per second. 


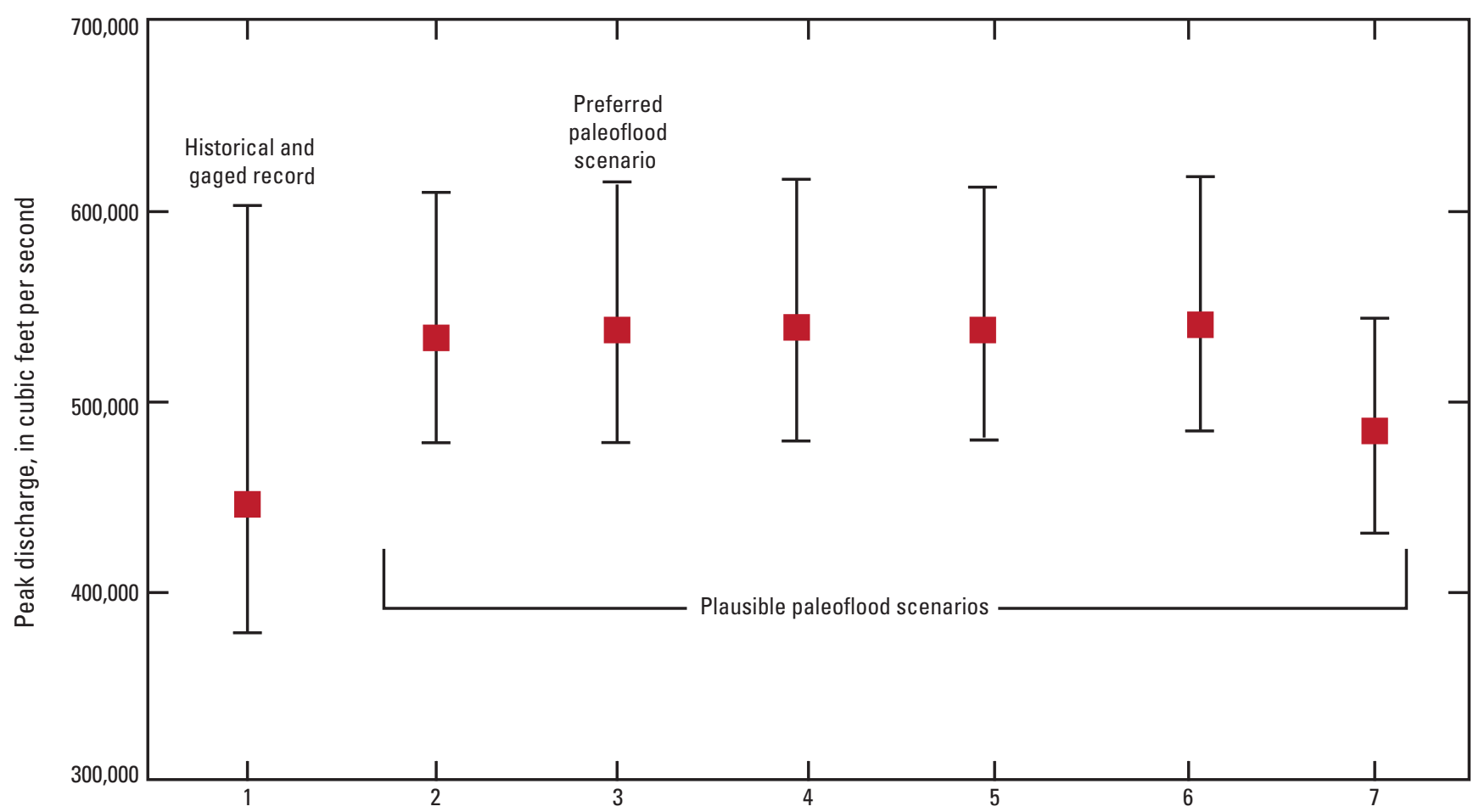

Results for the 0.001 annual exceedance probability from the flood-frequency analyses of the seven flood scenarios

\section{EXPLANATION}

Fitted frequency curve estimate

I95-percent confidence limit

Figure 29. Estimated discharges (squares) and 95-percent confidence limits (black vertical lines) of the flood-frequency analyses for the seven flood scenarios for the 0.001 annual exceedance probability, Tennessee River, Tennessee. Scenarios 2-7 incorporate the paleoflood data in the flood-frequency analysis with the gaged and historical data (scenario 1) and show an increase in the discharge estimate and a substantial narrowing of the confidence limits.

\section{Summary}

Paleoflood hydrology incorporates geological and botanical evidence to reconstruct the magnitude and frequency of large floods prior to observational records. The primary purpose of this comprehensive field study was to use paleoflood hydrology methods to improve estimates of flood-frequency for the Tennessee River near Chattanooga, Tennessee.

The main source of information used to improve floodfrequency estimates was stratigraphic records of large, previously unrecorded floods preserved along the valley bottom flanking the Tennessee River. The overall approach was to (1) develop a flood chronology for the Tennessee River near Chattanooga using stratigraphic analyses and geochronology from multiple sites at multiple elevations; (2) estimate peak flow magnitudes associated with elevations of flood evidence using a one-dimensional hydraulic model; (3) combine the information obtained from steps 1 and 2 to develop geologically based scenarios of timing and magnitude of large floods in the study reach; and (4) use all available information (including paleoflood, gaged, and historical records of flooding) to estimate the frequency of large Tennessee River floods.

Within the Tennessee River Gorge study area, most preserved flood deposits suitable for stratigraphic analysis accumulated beneath large colluvial sandstone boulders along hillslopes, in caves, underneath bedrock ledges, and in alcoves. Sites at multiple elevations were examined to more accurately define the frequency of flooding at different stages and to define an upper limit of mid-to-late Holocene flood magnitude. Flood ages were determined by radiocarbon analysis using carbon-14 and optically stimulated luminescence (OSL) analysis.

A key aspect of any paleoflood record is estimation of flood magnitudes associated with flood evidence preserved in the stratigraphic record. The method for estimating peak flow magnitudes was application of a one-dimensional, steadyflow U.S. Army Corps of Engineers Hydraulic Engineering 
Center-River Analysis System model originally developed by the Tennessee Valley Authority and modified for this analysis of paleoflood deposits.

The stratigraphy of 17 different sites, geochronology obtained from 25 radiocarbon and 8 OSL analyses, and estimates of stage-discharge relations at the study sites from the hydraulic modeling were distilled into an overall chronology of the number, timing, and magnitude of large unrecorded floods indicating eight unique paleofloods in the last 4,000 years. The four paleofloods included in the flood-frequency analysis are those of discharges and time periods for which we infer that the paleoflood record is complete and appropriate for the analysis. One of these paleofloods had discharges exceeding 470,000 cubic feet per second $\left(\mathrm{ft}^{3} / \mathrm{s}\right)$, a magnitude slightly greater than the historical flood of $1867,459,000 \mathrm{ft}^{3} / \mathrm{s}$ at the U.S. Geological Survey Chattanooga streamgage. One flood in the stratigraphic record, referred to as the Red Flower flood, was much larger than any historical or other paleoflood of the last 4,000 years. Its discharge, estimated at 1,100,000 $\mathrm{ft}^{3} / \mathrm{s}$, approached the envelope curve bounding the largest floods measured in the United States or Puerto Rico. It likely dates to the mid-to-late 1600s. Two additional floods within the last 1,000 years had estimated magnitudes of 420,000 and $400,000 \mathrm{ft}^{3} / \mathrm{s}$.

Flood-frequency analyses were done for seven flood scenarios using the U.S. Geological Survey software program PeakFQ v7.2 that follows the Guidelines for Determining Flood Flow Frequency-Bulletin 17C. The scenarios enable evaluation of the effects of adding the paleoflood data, plus assessment of how uncertainty in the paleoflood data may affect flood-frequency estimates. The analysis results show that incorporating the paleoflood data in the flood-frequency analysis increases the estimated discharge of low annual exceedance probability (AEP) floods. For example, analysis of just the historical and gaged record results in an estimate of $450,000 \mathrm{ft}^{3} / \mathrm{s}$ for the 0.001 AEP flood, compared to that of $540,000 \mathrm{ft}^{3} / \mathrm{s}$ obtained by including the paleoflood data of our preferred scenario. This result owes chiefly to inclusion of the exceptionally large Red Flower flood. Other uncertainties in the paleoflood record have little effect on the quantile estimates for low AEP floods. Incorporating the paleoflood information in the flood-frequency analysis also markedly improves the precision of estimates of low-probability floods - most clearly indicated by substantial narrowing of the 95-percent confidence limits. The confidence limit for the 1,000-year quantile estimate for our preferred paleoflood scenario (scenario 3) is $480,000-620,000 \mathrm{ft}^{3} / \mathrm{s}$ compared to $380,000-610,000 \mathrm{ft}^{3} / \mathrm{s}$ for the gaged and historical record only (scenario 1), a reduction of 38 percent. The discharge between the upper- and lower-95 percent confidence limits was reduced by $22-44$ percent when the preferred paleoflood record was added to the gaged and historical record for all flood quantile estimates from 100 to 10,000 years in the flood-frequency analysis.

\section{References Cited}

Baker, V.R., 1987, Paleoflood hydrology and extraordinary flood events: Journal of Hydrology (Amsterdam), v. 96, no. 1-4, p. 79-99.

Baker, V.R., 1989, Magnitude and frequency of paleofloods, in Beven, K., and Carling, P., eds., Floods-Hydrological, sedimentological, and geomorphological implications: New York, John Wiley and Sons, p. 171-183.

Baker, V.R., 2008, Paleoflood hydrology-Origin, progress, prospects: Geomorphology, v. 101, no. 1-2, p. 1-13.

Baker, V.R., Kochel, R.C., and Patton, P.C., 1979, Longterm flood-frequency analysis using geological data: International Association of Hydrological Science Publication, v. 128, p. 3-9.

Baker, V.R., Kochel, R.C., and Patton, P.C., eds., 1988, Flood geomorphology: New York, John Wiley and Sons, 503 p.

Benito, G., Lang, M., Barriendos, M., Llasat, M.C., Francés, F., Ouarda, T., Thorndycraft, V., Enzel, Y., Bardossy, A., Coeur, D., and Bobée, B., 2004, Use of systematic, paleoflood and historical data for the improvement of flood risk estimation-Review of scientific methods: Natural Hazards, v. 31, no. 3, p. 623-643, https://doi.org/10.1023/B:NHAZ $.0000024895 .48463 . \mathrm{eb}$.

Benito, G., and O'Connor, J.E., 2013, Quantitative paleoflood hydrology, in Shroder, J.F., editor-in-chief, and Wohl, E., volume editor, Treatise on geomorphology, v. 9, Fluvial geomorphology: San Diego, California, Academic Press, p. $459-474$.

Blainey, J.B., Webb, R.H., Moss, M.E., and Baker, V.R., 2002, Bias and information content of paleoflood data in flood-frequency analysis, in House, P.K., Webb, R.H., Baker, V.R., and Levish, D.R., eds., Ancient floods, modern hazards - Principles and applications of paleoflood hydrology: Water and Science Application Series 5: Washington, D.C., American Geophysical Union, p. 161-174.

Blong, R.J., and Gillespie, R., 1978, Fluvially transported charcoal gives erroneous ${ }^{14} \mathrm{C}$ ages for recent deposits: Nature, v. 271, no. 5647, p. 739-741, https://doi.org/ $10.1038 / 271739 \mathrm{a} 0$.

Bretz, J.H., 1923, The channeled scabland of the Columbia Plateau: The Journal of Geology, v. 31, no. 8, p. 617-649.

Bretz, J.H., 1928, Channeled scabland of eastern Washington: Geographical Review, v. 18, no. 3, p. 446-477, https://doi.org/10.2307/208027.

Bretz, J.H., 1929, Valley deposits immediately east of the channeled scabland of Washington: The Journal of Geology, v. 37 , no. 6 , p. 505-541. 
Bronk Ramsey, C., 1994, Analysis of chronological information and radiocarbon calibration-The Program OxCal: Archaeological Computing Newsletter, v. 41, p. 11-16.

Bronk Ramsey, C., 2009, Bayesian analysis of radiocarbon dates: Radiocarbon, v. 51, no. 1, p. 337-360.

Bronk Ramsey, C., van der Plicht, J., and Weninger, B., 2001, 'Wiggle matching' radiocarbon dates: Radiocarbon, v. 43, no. 2A, p. 381-389, https://doi.org/10.1017/ S0033822200038248.

Brunner, G.W., 2010b, HEC-RAS river analysis system hydraulic reference manual-Computer program documentation CPD-69: Davis, California, U.S. Army Corps of Engineers Institute for Water Resources, Hydrologic Engineering Center, $407 \mathrm{p}$.

Brunner, G.W., 2010a, HEC-RAS river analysis system user's manual, version 4.1 - Computer program documentation CPD-68: Davis, California, U.S. Army Corps of Engineers, Institute for Water Resources, Hydrologic Engineering Center, $774 \mathrm{p}$.

Cohn, T.A., Lane, W.L., and Baier, W.G., 1997, An algorithm for computing moments-based quantile estimates when historical flood information is available: Water Resources Research, v. 33, no. 9, p. 2089-2096.

Cohn, T.A., Lane, W.L., and Stedinger, J.R., 2001, Confidence intervals for expected moments algorithm flood quantile estimates: Water Resources Research, v. 37, no. 6, p. 1695-1706.

Costa, J.E., 1978, Holocene stratigraphy in flood frequency analysis: Water Resources Research, v. 14, no. 4, p. 626-632.

Crippen, J.R., and Bue, C.D., 1977, Maximum floodflows in the conterminous United States: U.S. Geological Survey Water-Supply Paper 1887, 52 p.

Cunningham, A.C., Wallinga, J., Hobo, N., Versendaal, A.J., Makaske, B., and Middelkoop, H., 2015, Re-evaluating luminescence burial doses and bleaching of fluvial deposits using Bayesian computational statistics: Earth Surface Dynamics, v. 3, no. 1, p. 55-65.

Cunningham, A.C., Wallinga, J., and Minderhoud, P.S.J., 2011, Expectations of scatter in equivalent-dose distributions when using multi-grain aliquots for OSL dating: Geochronometria, v. 38, no. 4, p. 424-432, https://doi.org/ 10.2478/s13386-011-0048-z.
Davis, L., Lombardi, R., Sterart, C.L., Stinchcomb, G.E., Forman, S.L., Yaw, M., and Jawdy, C.M., 2019, Characterizing extreme floods on the middle Tennessee River, Alabama (USA) using a paleoflood chronology, American Geophysical Union Annual Meeting, San Francisco, December 9-12, 2019: Washington, D.C., American Geophysical Union, Abstract No. H44F-04.

Duller, G.A.T., 2008, Luminescence dating - Guidelines on using luminescence dating in archaeology: Swindon, United Kingdom, English Heritage Publishing, 43 p.

Edelen, G.W., Jr., and Miller, J.F., 1976, Floods of MarchApril 1973 in the southeastern United States: U.S. Geological Survey Professional Paper 998, 294 p.

Ely, L.L., and Baker, V.R., 1985, Reconstructing paleoflood hydrology with slackwater deposits - Verde River, Arizona: Physical Geography, v. 6, no. 2, p. 103-126.

England, J.F., Jr., Cohn, T.A., Faber, B.A., Stedinger, J.R., Thomas, W.O., Jr., Veilleux, A.G., Kiang, J.E., and Mason, R.R., Jr., 2018, Guidelines for determining flood flow frequency—Bulletin 17C: U.S. Geological Survey Techniques and Methods, book 4, chap. B5, 148 p., https://doi.org/10.3133/tm4B5.

England, J.F., Jr., Godaire, J.E., Klinger, R.E., Bauer, T.R., and Julien, P.Y., 2010, Paleohydrologic bounds and extreme flood frequency of the upper Arkansas River, Colorado, USA: Geomorphology, v. 124, no. 1-2, p. 1-16.

England, J.F., Jr., Salas, J.D., and Jarrett, R.D., 2003, Comparisons of two moments-based estimators that utilize historical and paleoflood data for the log-Pearson Type III distribution: Water Resources Research, v. 39, no. 9, 16 p., https://doi.org/10.1029/2002WR001791.

Flynn, K.M., Kirby, W.H., and Hummel, P.R., 2006, User's manual for program PeakFQ - Annual flood frequency analysis using Bulletin 17B guidelines: U.S. Geological Survey Techniques and Methods, book 4, chap. B4, 42 p.

Frances, F., Salas, J.D., and Boes, D.C., 1994, Flood frequency analysis with systematic and historical or paleoflood data based on the two-parameter general extreme value models: Water Resources Research, v. 30, no. 6, p. 1653-1664.

Galbraith, R.F., and Roberts, R.G., 2012, Statistical aspects of equivalent dose and error calculation and display in OSL dating - An overview and some recommendations: Quaternary Geochronology, v. 11, p. 1-27.

Greenbaum, N., Harden, T.M., Baker, V.R., Weisheit, J., Cline, M.L., Porat, N., Halevi, R., and Dohrenwend, J., 2014, A 2000-year natural record of magnitudes and frequencies for the largest Upper Colorado River floods near Moab, Utah: Water Resources Research, v. 50, no. 6, p. 5249-5269. 
Harden, T.M., 2021, Hydraulic modeling and flood-frequency analyses using paleoflood hydrology for the Tennessee River near Chattanooga, Tennessee: U.S. Geological Survey data release, https://doi.org/10.5066/P914SLVM.

Harden, T.M., and O'Connor, J.E., 2017, Prehistoric floods on the Tennessee River-Assessing the use of stratigraphic records of past floods for improved flood-frequency analysis: U.S. Geological Survey Scientific Investigations Report 2017-5052, 15 p., https://doi.org/10.3133/sir20175052.

Harden, T.M., O'Connor, J.E., Driscoll, D.G., and Stamm, J.F., 2011, Flood-frequency analyses from paleoflood investigations for Spring, Rapid, Boxelder, and Elk Creeks, Black Hills, western South Dakota: U.S. Geological Survey Scientific Investigations Report 2011-5131, 136 p.

Herget, J., and Fontana, A., eds., 2020, PalaeohydrologyTraces, tracks, and trails of extreme events: Cham, Switzerland, Springer Nature, 230 p., https://doi.org/ 10.1007/978-3-030-23315-0.

Hosking, J.R.M., and Wallis, J.R., 1986, Paleoflood hydrology and flood frequency analysis: Water Resources Research, v. 22 , no. 4 , p. 543-550.

Hosman, K.J., Ely, L.L., and O'Connor, J.E., 2003, Holocene paleoflood hydrology of the lower Deschutes River, in O'Connor, J.E., and Grant, G.E., eds., A peculiar riverGeology, geomorphology, and hydrology of the Deschutes River, Oregon: American Geophysical Union Water Science and Application Series No. 7, p. 121-146.

Jahns, R.H., 1947, Geologic features of the Connecticut Valley, Massachusetts, as related to recent floods: U.S. Geological Survey Water-Supply Paper 996, 158 p.

Jarrett, R.D., and Tomlinson, E.M., 2000, Regional interdisciplinary paleoflood approach to assess extreme flood potential: Water Resources Research, v. 36, no. 10, p. 2957-2984.

Kammerer, J.C., 1990, Water fact sheet-Largest rivers in the United States: U.S. Geological Survey Open-File Report $87-242,2 \mathrm{p}$.

Kochel, R.C., and Baker, V.R., 1988, Paleoflood analysis using slackwater deposits, in Baker, V.R., Kochel, R.C., and Patton, P.C., eds., Flood geomorphology: New York, John Wiley and Sons, p. 357-376.

Kohn, M.S., Stevens, M.R., Harden, T.M., Godaire, J.E., Klinger, R.E., and Mommandi, A., 2016, Paleoflood investigations to improve peak-streamflow regional-regression equations for natural streamflow in eastern Colorado, 2015: U.S. Geological Survey Scientific Investigations Report 2016-5099, 58 p., https://doi.org/10.3133/sir20165099.
Kubas, H.R., 2017, Modeling paleofloods in the Tennessee Valley - Calibrating the naturals model and associating flood deposits with flows: Knoxville, University of Tennessee, Master's thesis, 61 p., https://trace.tenn essee.edu/utk_gradthes/5008.

Kurokawa, K., Ishibashi, K., Oshima, K., Sakiyama, H., Sakurai, M., Tanaka, M., Nomura, S., Hachisuka, R., and Yokoyama, Y., 2012, The official report of The Fukushima Nuclear Accident Independent Investigation CommissionExecutive summary: The National Diet of Japan, 86 p. [In English.]

Lam, D., Thompson, C., Croke, J., Sharma, A., and Macklin, M., 2017, Reducing uncertainty with flood frequency analysis - The contribution of paleoflood and historical flood information: Water Resources Research, v. 53, no. 3, p. 2312-2327.

Levish, D.R., 2002, Paleohydrologic bounds-Nonexceedance information for flood hazard assessment, in House, P.K., Webb, R.H., Baker, V.R., and Levish, D.R., eds., Ancient floods, modern hazards-Principles and applications of paleoflood hydrology: Water and Science Application Series 5: Washington, D.C., American Geophysical Union, p. 175-190.

Marren, P.M., Grave, J.R., Webb, J.A., and Stewardson, M.J., 2014, The potential for dams to impact lowland meandering river floodplain geomorphology: Scientific World Journal, 24 p., https://doi.org/10.1155/2014/309673.

Murray, A.S., Thomsen, K.J., Masuda, N., Buylaert, J.P., and Jain, M., 2012, Identifying well-bleached quartz using the different bleaching rates of quartz and feldspar luminescence signals: Radiation Measurements, v. 47, no. 9, p. 688-695. https://doi.org/10.1016/j.radmeas.2012.05.006.

National Geodetic Survey, 2019, VERCON orthometric height conversion: National Oceanic and Atmospheric Administration web page, https://www.ngs.noaa.gov/cgibin/VERTCON/vert_con.prl.

National Resource Council, 2014, Lessons learned from the Fukushima nuclear accident for improving safety of U.S. nuclear plants: Washington, D.C., The National Academies Press, $366 \mathrm{p}$.

O'Connell, D.R.H., 1999, FLDFRQ3 - Three-parameter maximum likelihood flood-frequency estimation with optional probability regions using parameter grid integrationUser's guide (release 1.1): Denver, Colorado, Bureau of Reclamation, $19 \mathrm{p}$.

O'Connell, D.R.H., Ostenaa, D.A., Levish, D.R., and Klinger, R.E., 2002, Bayesian flood frequency analysis with paleohydrologic bound data: Water Resources Research, v. 38, no. 5, 14 p, https://doi.org/10.1029/2000WR000028. 
O’Connor, J.E., Atwater, B.F., Cohn, T.A., Cronin, T.M., Keith, M.K., Smith, C.G., and Mason, R.R., 2014, Assessing inundation hazards to nuclear powerplant sites using geologically extended histories of riverine floods, tsunamis, and storm surges: U.S. Geological Survey Scientific Investigations Report 2014-5207, 66 p., https://doi.org/ $10.3133 / \operatorname{sir} 20145207$.

O’Connor, J.E., and Costa, J.E., 2003, Large floods in the United States - Where they happen and why: U. S. Geological Survey Circular 1245, 13 p.

O’Connor, J.E., Ely, L.L., Wohl, E.E., Stevens, L.E., Melis, T.S., Kale, V.S., and Baker, V.R., 1994, A 4500-year record of large floods on the Colorado River in the Grand Canyon, Arizona: The Journal of Geology, v. 102, no. 1, p. 1-9.

Patton, P.C., 1987, Measuring rivers of the past-A history of fluvial paleohydrology, in Landa, E.R., and Ince, S., eds., The history of hydrology-History of geophysics, volume 3: Washington, D.C., American Geophysical Union, p. 55-67.

Patton, P.C., Baker, V.R., and Kochel, R.C., 1979, Slack water deposits - A geomorphic technique for the interpretation of fluvial paleohydrology, in Rhodes, D.D., and Williams, G.P., eds., Adjustments of the fluvial system: Dubuque, Iowa, Kendall/Hunt Publishing Company, p. 225-253.

Petticord, D., 2013, Ancient places - Chattanooga Magazine: Chattanooga, Tennessee, Tennessee River Gorge Trust, 4 p., https://www.trgt.org/publications.

Prescott, J.R., and Hutton, J.T., 1994, Cosmic ray contributions to dose rates for luminescence and ESR datingLarge depths and long-term time variations: Radiation Measurements, v. 23, no. 1-2, p. 497-500, https://doi.org/ 10.1016/1350-4487(94)90086-8.

Reimer, P.J., Baillie, M.G.L., Bard, E., Bayliss, A., Beck, J.W., Blackwell, P.G., Bronk Ramsey, C., Buck, C.E., Burr, G.S., Edwards, R.L., Friedrich, M., Grootes, P.M., Guilderson, T.P., Hajdas, I., Heaton, T.J., Hogg, A.G., Hughen, K.A., Kaiser, K.F., Kromer, B., McCormac, F.G., Manning, S.W., Reimer, R.W., Richards, D.A., Southon, J.R., Talamo, S., Turney, C.S.M., van der Plicht, J., and Weyhenmeyer, C.E., 2009, IntCal09 and Marine09 radiocarbon age calibration curves, 0-50,000 years cal BP: Radiocarbon, v. 51, no. 4, p. 1111-1150.

Reimer, P.J., Bard, E., Bayliss, A., Beck, J.W., Blackwell, P.G., Bronk Ramsey, C., Grootes, P.M., Guilderson, T.P., Haflidason, H., Hajdas, I., Hatté, C., Heaton, T.J., Hoffmann, D.L., Hogg, A.G., Hughen, K.A., Kaiser, K.F., Kromer, B., Manning, S.W., Niu, M., Reimer, R.W., Richards, D.A., Scott, E.M., Southon, J.R., Staff, R.A., Turney, C.S.M., and van der Plicht, J., 2013, IntCal13 and Marine 13 radiocarbon age calibration curves 0-50,000 years cal BP: Radiocarbon, v. 55, no. 4, p. 1869-1887.
Rittenour, T.M., 2008, Luminescence dating of fluvial deposits-Applications to geomorphic, paleoseismic and archaeological research: Boreas, v. 37, no. 4, p. 613-635.

Salas, J.D., Wohl, E.E., and Jarrett, R.D., 1994, Determination of flood characteristics using systematic, historical and paleoflood data, chap. 7 of Rossi, G., Harmancioğlu, N., and Yevjevich, V., eds., Coping with floods-NATO ASI Series (Series E-Applied Sciences), volume 257: Dordrecht, The Netherlands, Springer, p. 111-134, https://doi.org/10.1007/ 978-94-011-1098-3 7.

Smithsonian Institution, 2020, Hales Bar Dam Collection, 1905-1968: National Museum of American History Archives Collection, accessed April 2020, at https://sova.si.edu/record/NMAH.AC.1051.

Speer, P.R., and Gamble, C.R., 1964, Magnitude and frequency of floods in the United States, Part 3-B, Cumberland and Tennessee River Basins: U.S. Geological Survey WaterSupply Paper 1676, 340 p.

Stedinger, J.R., and Baker, V.R., 1987, Surface water hydrology-Historical and paleoflood information: Reviews of Geophysics, v. 25, no. 2, p. 119-124.

Stedinger, J.R., and Cohn, T.A., 1986, Flood frequency analysis with historical and paleoflood information: Water Resources Research, v. 22, no. 5, p. 785-793, https://doi.org/10.1029/WR022i005p00785.

Stewart, J.E., and Bodhaine, G.L., 1961, Floods in the Skagit River Basin, Washington: U.S. Geological Survey Water Supply Paper 1527, 66 p.

Stuiver, M., and Polach, H.A., 1977, Discussion-Reporting of ${ }^{14} \mathrm{C}$ data: Radiocarbon, v. 19 , no. 3, p. 355-363.

Taylor, R.E., 2001, Radiocarbon dating, in Brothwell, D.R., and Pollard, A.M., eds., Handbook of archaeological sciences: Chichester, United Kingdom, and New York, John Wiley, p. 23-24.

Tennessee Department of Finance and Administration, 2020, Elevation/LiDAR: Tennessee Department of Finance and Administration database, https://www.tn.gov/finance/sts-gis/ gis/gis-projects/gis-projects-elevation.

Tennessee Valley Authority, 1939, The Chattanooga flood control problem-House Document No. 91, 76th Congress, 1st Session: Washington, D.C., Government Printing Office, $137 \mathrm{p}$.

Tennessee Valley Authority, 1940, Flood profiles, Tennessee River-Mile 350-370, Flood control investigations: Knoxville, Tennessee, Tennessee Valley Authority, Water Control Planning Department, Engineering drawing 1K112R, 1 pl. 
Tennessee Valley Authority, 1961, Floods and flood control: Knoxville, Tennessee, Tennessee Valley Authority, Technical Report No. 26, 302 p.

Tennessee Valley Authority, 1974, Floods of March 1973 in the Tennessee River Basin: Knoxville, Tennessee., Tennessee Valley Authority, Report No. 0-7129, 91 p.

Tennessee Valley Authority, 1993, Sensitivity of the TVA reservoir and power supply systems to extreme meteorology: Tennessee Valley Authority Engineering Laboratory, Norris, Tennessee, Report No. WR28-1-680-111, 166 p.

Tennessee Valley Authority, 2014, Watts Bar Unit 1, Submittal of application to revise updated final safety analysis report re changes to hydrologic analysis (WBN-UFSAR-12-01): U.S. Nuclear Regulatory Commission web page, accessed January 2019, at https://www.nrc.gov/docs/ML1428/ ML14289A106.html.

Tennessee Valley Authority, 2015, Flood hazard reevaluation report for Watts Bar Nuclear Plant-Response to NRC Request for Information pursuant to Title 10 of the Code of Federal Regulations 50.54(f) regarding recommendations 2.1, 2.3, and 9.3 of the Near-Term Task Force review of insights from the Fukushima Dai-ichi Accident: Tennessee Valley Authority, 4 p., accessed November 2018, at https://www.nrc.gov/docs/ML1508/ML15084A324.pdf.

U.S. Geological Survey, 2019b, Luminescence Dating Laboratory, Lakewood, Colorado: U.S. Geological Survey web site, accessed March 22, 2019, at https://www .usgs.gov/centers/gecsc/labs/luminescence-datinglaboratory.

U.S. Geological Survey, 2019a, National Water Information System-Web interface: U.S. Geological Survey database, accessed December 2017-October 2019, at https://waterdata .usgs.gov/nwis.
U.S. Geological Survey, 2020, 3D elevation program: U.S. Geological Survey web page, https:/www.usgs.gov/corescience-systems/ngp/3dep.

Veilleux, A.G., Cohn, T.A., Flynn, K.M., Mason, R.R., Jr., and Hummel, P.R., 2014, Estimating magnitude and frequency of floods using the PeakFQ 7.0 program: U.S. Geological Survey Fact Sheet 2013-3108, 2 p., https://doi.org/10.3133/ fs20133108.

Walker, M., 2005, Quaternary dating methods: Chichester, United Kingdom, John Wiley and Sons, Ltd., 286 p.

Wallinga, J., 2002, Optically stimulated luminescence dating of fluvial deposits-A review: Boreas, v. 31, no. 4, p. 303-322.

Webb, R.H., Blainey, J.B., and Hyndman, D.W., 2002, Paleoflood hydrology of the Paria River, southern Utah and Northern Arizona, USA, in House, P.K., Webb, R.H., Baker, V.R., and Levish, D.L., eds., Ancient floods, modern hazards - Principles and applications of paleoflood hydrology v. 5: Washington, D.C., American Geophysical Union's Water Science and Application Series, p. 295-310.

Webb, R.H., O’Connor, J.E., and Baker, V.R., 1988, Paleohydrologic reconstruction of flood frequency on the Escalante River, south-central Utah, in Baker, V.R., Kochel, R.C., and Patton, P.C., eds., Flood geomorphology: New York, John Wiley and Sons, p. 403-418.

World Nuclear Association, 2018, Fukushima Daiichi accident: London, United Kingdom, World Nuclear Association web page, https://www.world-nuclear.org/informationlibrary/safety-and-security/safety-of-plants/fukushimadaiichi-accident.aspx. 


\section{Appendix 1. Stratigraphic Descriptions of Supporting Paleoflood Sites}

The stratigraphic descriptions of key sites contributing to the flood-frequency analyses in this study are described in the body of the report. The following are stratigraphic descriptions of supporting sites used to confirm findings of the key sites.

\section{Goose Wallow}

The Goose Wallow site, named for what looked like shallow goose wallow marks on the surface sediment, is about $50 \mathrm{~m}$ downstream from the Red Flower site and at $676.07 \mathrm{ft}$ above NAVD 88, is about $3 \mathrm{ft}$ lower in elevation than Red Flower (fig. 10). This site was specifically evaluated to confirm the Red Flower flood interpretation.

The Goose Wallow site is at the base of a large sandstone boulder embedded in the valley slope colluvium (fig. 1.1). The boulder overhangs a narrow and flat 1-by-2.5 m area, sheltering a relatively dry and unvegetated area where the deposits are preserved and mostly protected from slope processes. Aside from the surface disturbance, the site is littered with organic debris including leaves, small sticks, and a few pebbles likely spalled from the boulder above.

$\mathrm{cm}$ are loose, light brown, pebbly silty sand with organic debris mixed throughout. This deposit is poorly sorted with isolated granules probably weathered out of the rock overhang. The upper half of this deposit has a few angular cobbles as much as $2-3$ centimeters in diameter and abundant leaves mixed with the sediment. This $12-\mathrm{cm}$ thick deposit of sediment likely is locally derived, weathered material from the rock overhang mixed with slope wash sediment and local organic detritus.

From about 12 to $23 \mathrm{~cm}$ bls lies brown, very fine sand. This deposit is more compact than the deposit above and below it and contains no visible pebbles or granules. No primary sedimentary structures are visible but there is a subhorizontal wavy texture. Small, shiny grains can be seen and appear to be mica flakes (as opposed to quartz, which is abundant in the area). However, the grains were very small and could not be positively identified in the field by a hand lens. This deposit is locally bioturbated by $3-4 \mathrm{~mm}$ roots and small insect burrows. The lower contact is irregular and locally marked by granules and pebbles as much as $1 \mathrm{~cm}$ in diameter. Based on the well-sorted nature of this deposit, the possible presence of mica, and its compact nature, this deposit likely is from the same flood that left a deposit at the Red Flower site.

Below this flood deposit lies $37 \mathrm{~cm}$ of orangish-brown, silty fine sand with granules and angular sandstone cobbles eroded from the sandstone overhang above. This deposit is loose, has no apparent primary structure, and has abundant roots. We interpret this deposit to be local slope wash mixed with rockfall fragments.
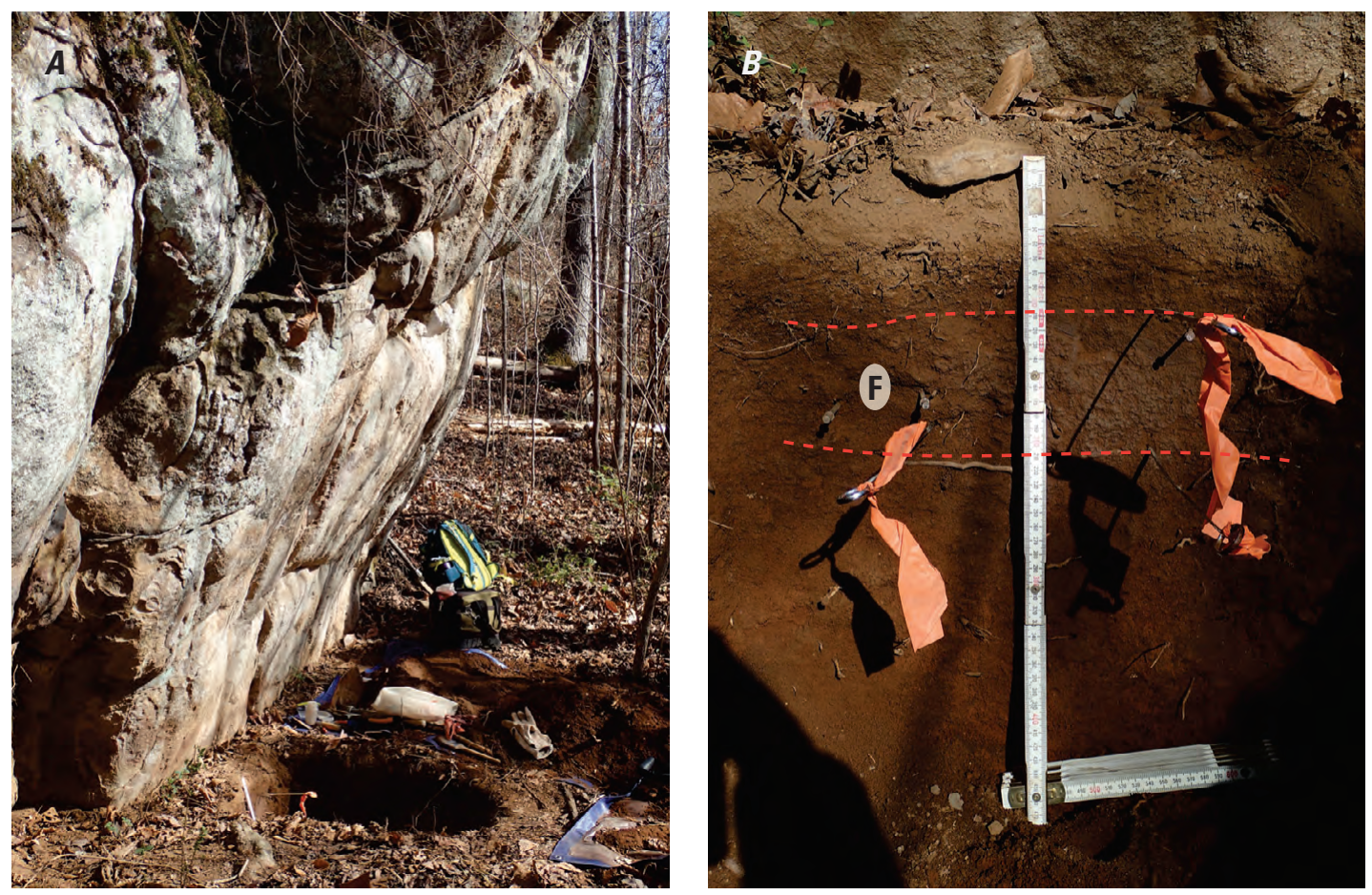

Figure 1.1. Location $(A)$ and stratigraphy $(B)$ of the pit at the Goose Wallow site, Tennessee River, Tennessee. This pit contains evidence of one extreme Tennessee River flood deposit. "F" indicates a flood deposit. 


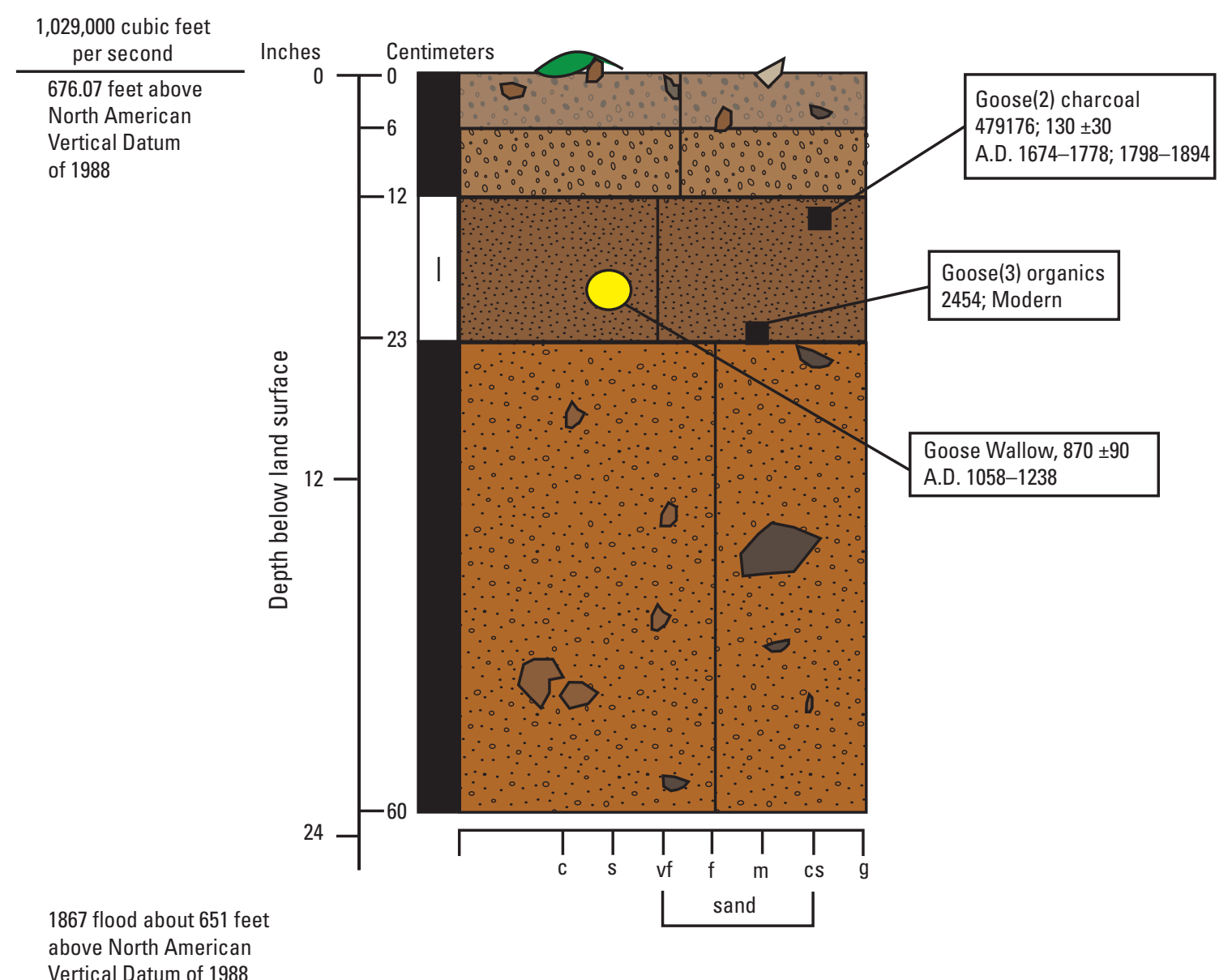

EXPLANATION
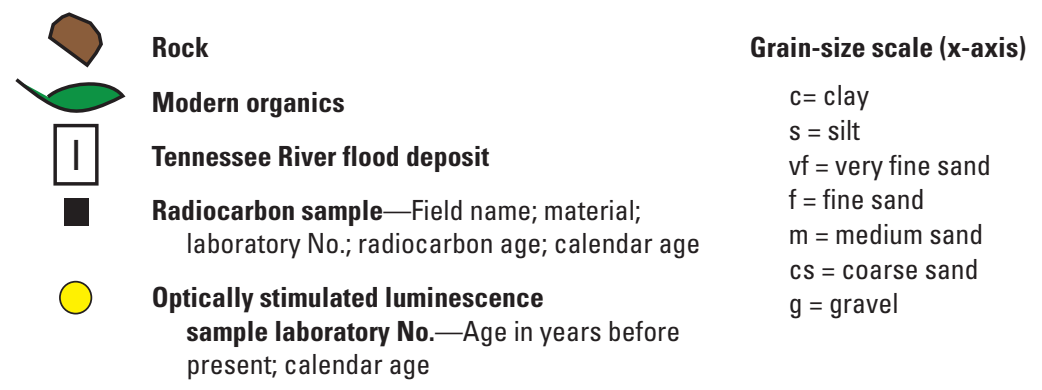

Figure 1.2. Goose Wallow site, Tennessee River, Tennessee.

The flood deposit here was dated using multiple methods. An optically simulated luminescence (OSL) sample at a depth of $17 \mathrm{~cm}$ in the flood deposit returned a date range of A.D. 1058-1238. If this age accurately dates the flood deposit, then that would signify two very large floods with minimum watersurface elevations almost 25-30 feet above the 1867 peak occurring in about the last 1,000 years or that the Red Flower flood is about 1,000 years old, instead of the approximately 350 -year-old date from the carbon-14 $\left({ }^{14} \mathrm{C}\right)$ analysis at the Red Flower site and other sites. More likely, the OSL sample was only partially bleached and overestimates the date at which the sediment was deposited during the last flood, or, owing to bioturbation, the sample represents a combination of flood sediment and older sediment from the unit below. This sample has 100-percent scatter that supports this idea. Scatter is the variation in equivalent dose $\left(\mathrm{D}_{\mathrm{e}}\right)$, or the amount of laboratory radiation that is equivalent to what the grains received during burial (Duller, 2008). Scatter values higher than about 20-30 percent are considered to be poorly bleached or mixed sediment (Murray and others, 2012; table 3).

Two organic samples were sent for radiocarbon analysis and returned date ranges of A.D. 1674-1778 and A.D. 1798-1894 for one sample near the upper contact and "modern" for a sample at the lower contact. The "modern" age is an age that post-dates 1950 , when excess ${ }^{14} \mathrm{C}$ was introduced into the atmosphere owing to nuclear bomb testing. This sample 
probably was post-1950 material recently embedded in the deposit by burrowing. The older sample from near the top of the deposit gave a result very similar to that within a similar position in the flood deposit at the Red Flower site, consistent with a flood date of sometime in the mid-to-late 1600 s.

The minimum discharge required to inundate this site is $1,000,000 \mathrm{ft}^{3} / \mathrm{s}$. Considering the characteristics of the deposit, the available age information, and the deposit elevation, we conclude that it also records an outstanding flood of more than $1,000,000 \mathrm{ft}^{3} / \mathrm{s}$, almost certainly the same exceptional $17 \mathrm{th}$ - (or 18th) century flood preserved at the Red Flower site.

\section{Milled Wood}

At about river mile (RM) 445, elevation $653.90 \mathrm{ft}$, is a small alcove formed by a large sandstone slab resting on several smaller sandstone boulders (fig. 1.3). A 2-ft piece of decayed milled wood was found on the floor of the alcove. The wood was partially wedged into sediment near the back of the alcove in such a way as to make it hard to discern if it was driftwood from a Tennessee River flood or human-placed. A small 28-cm-deep pit was dug near the wood (fig. 1.4). The top $10 \mathrm{~cm}$ of the of this pit was loose, poorly sorted grayishbrown silty fine sand with abundant granules and angular clasts as much as $3 \mathrm{~cm}$ in diameter. Although the surface is covered by organic debris (leaves, sticks), organic material below the surface is scarce. The next $7 \mathrm{~cm}$ in depth are similar, but slightly more compact and contain smaller gravel clasts $(<0.5 \mathrm{~cm})$. At a depth of $17-28 \mathrm{~cm}$, the sediment is very compact, orangish-brown silty fine-to-medium sand. Angular clasts as much as $3 \mathrm{~cm}$ in diameter are present as well as roots as much as $1 \mathrm{~cm}$. The top 2 units (to $17 \mathrm{~cm}$ ) contain small mica flakes that are not present in the bottom $11 \mathrm{~cm}$, which would indicate Tennessee River flood waters reached this elevation in the recent past. However, there is no clear indication of an intact flood deposit, suggesting that any former flood deposits have been reworked by humans or natural processes.

A radiocarbon sample collected from a depth of $21 \mathrm{~cm}$ near the contact between the reworked flood deposit and the underlying locally derived deposit returned an age range

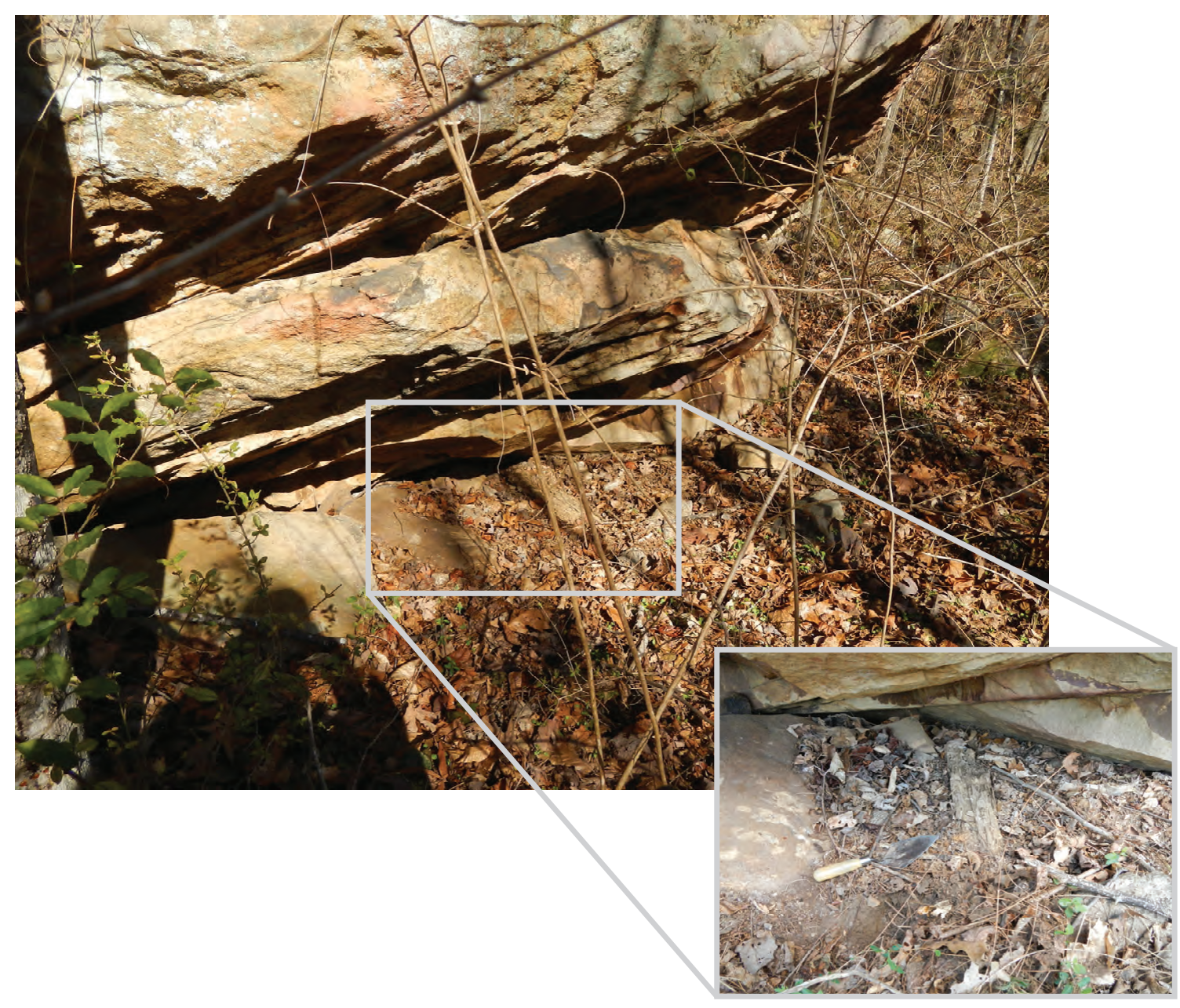

Figure 1.3. Location of the pit underneath a boulder and the milled wood (inset) that either floated on a flood wave or was human-placed, at the Milled Wood site, Tennessee River, Tennessee. 

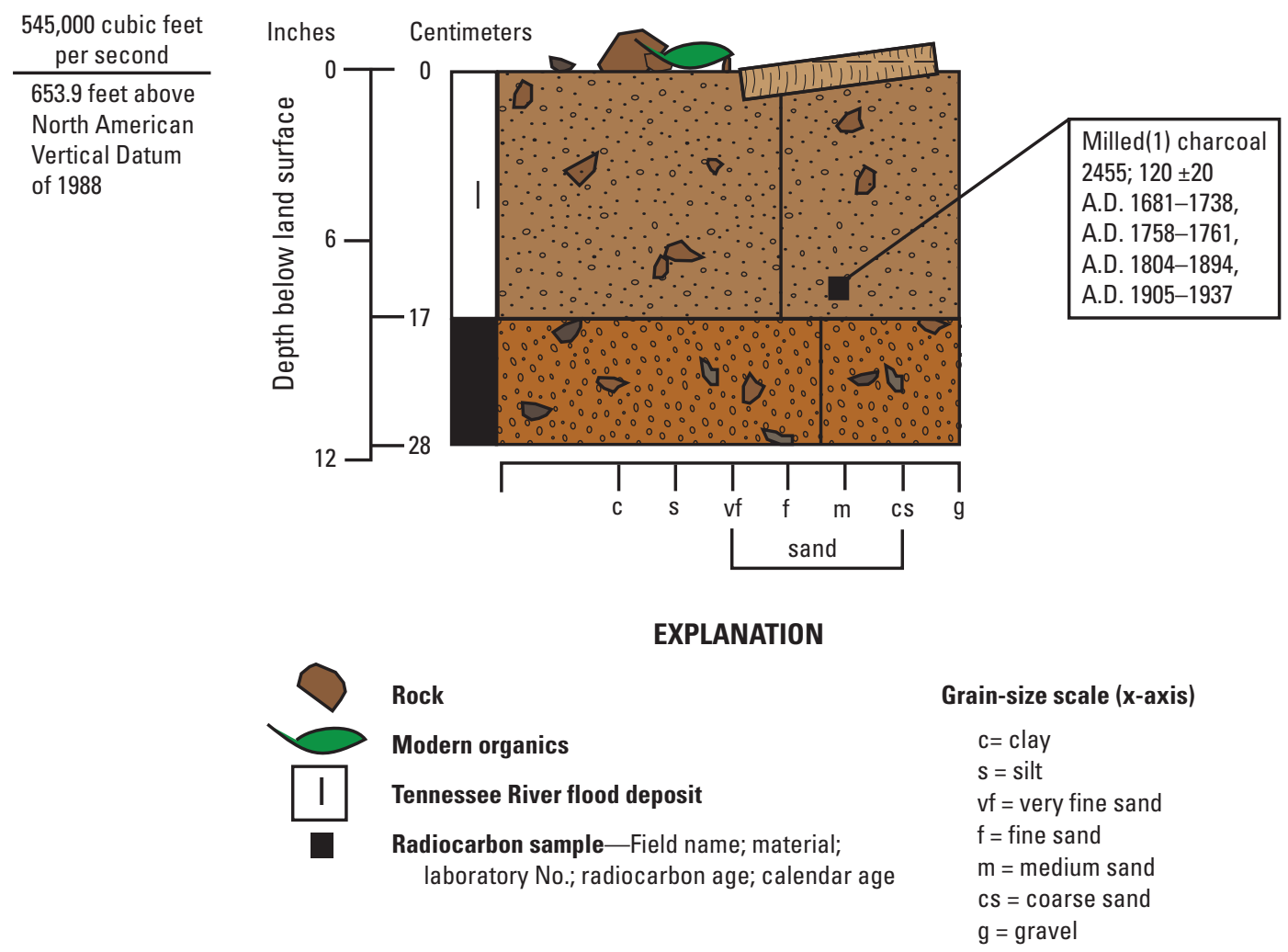

Figure 1.4. Stratigraphy at the Milled Wood site, Tennessee River, Tennessee.

of A.D. 1681-1937. Because of the reworked nature of the flood deposit, it is unclear if this age represents the age of the flood or an age of the local material. The elevation of this site $(653.90 \mathrm{ft})$ is more than $4 \mathrm{ft}$ higher than the 1867 watersurface elevation $(649 \mathrm{ft})$ at this location. This reworked flood deposit possibly is from the Red Flower flood; the elevation and age are consistent with this scenario. The minimum discharge required to inundate this site is $550,000 \mathrm{ft}^{3} / \mathrm{s}$, much less than the discharge of the Red Flower flood.

\section{Smirnoff}

The Smirnoff site, RM 445, is a 0.6 by $2 \mathrm{~m}$ alcove formed beneath a sandstone boulder (fig. 1.5) at an elevation of 648.4 $\mathrm{ft}$. The surface of the small alcove is partially covered by dried leaves, acorns, small sticks, an empty Smirnoff ${ }^{\mathrm{TM}}$ bottle, and moss in some areas where moisture is present. The deposit is capped by an about 1-3-cm-thick discontinuous layer of finely bedded silt, evidence of a recent Tennessee River flood. A pit was dug to expose the silt and other deposits of silt to a depth of $33 \mathrm{~cm}$ (fig. 1.6).
The first $10 \mathrm{~cm}$ under the silt cap are well-sorted brown very fine to fine sand with some silt and mica flakes. There are a few rounded gravel clasts as much as $2 \mathrm{~cm}$ in diameter that probably are locally derived. Aside from the $1 \mathrm{~cm}$ silt cap on the surface, there is no visible bedding. Roots are common with diameters as much as about $5 \mathrm{~mm}$. The bottom contact is defined by a discontinuous stone line, likely roof fall clasts. Granules are concentrated in the middle of this deposit that could represent the boundary of another deposit. This $10-\mathrm{cm}$ deposit represents 1-2 Tennessee River flood deposits in addition to the silt cap, or the silt cap could be associated with the flood deposit below.

The next $6 \mathrm{~cm}$ in the pit $(11-17 \mathrm{~cm})$ is very similar to the deposit above but with less silt and no gravel and is more compact than the unit above. Like the top contact, the basal contact is defined by a discontinuous stone line. This deposit is evidence of another Tennessee River flood. From 17 to 25 $\mathrm{cm}$ in depth lies brown very fine sand that contains mica. This deposit is similar in characteristics but less compact than the deposit above. This deposit also represents a flood. The basal deposit from 25 to $33 \mathrm{~cm}$ is orangish-brown, very fine to fine sand with subrounded to subangular gravel as much as $3 \mathrm{~cm}$ in diameter. One isolated cobble is about $10 \mathrm{~cm}$. This deposit is composed of local material derived from the adjacent slope and boulder overhang. 

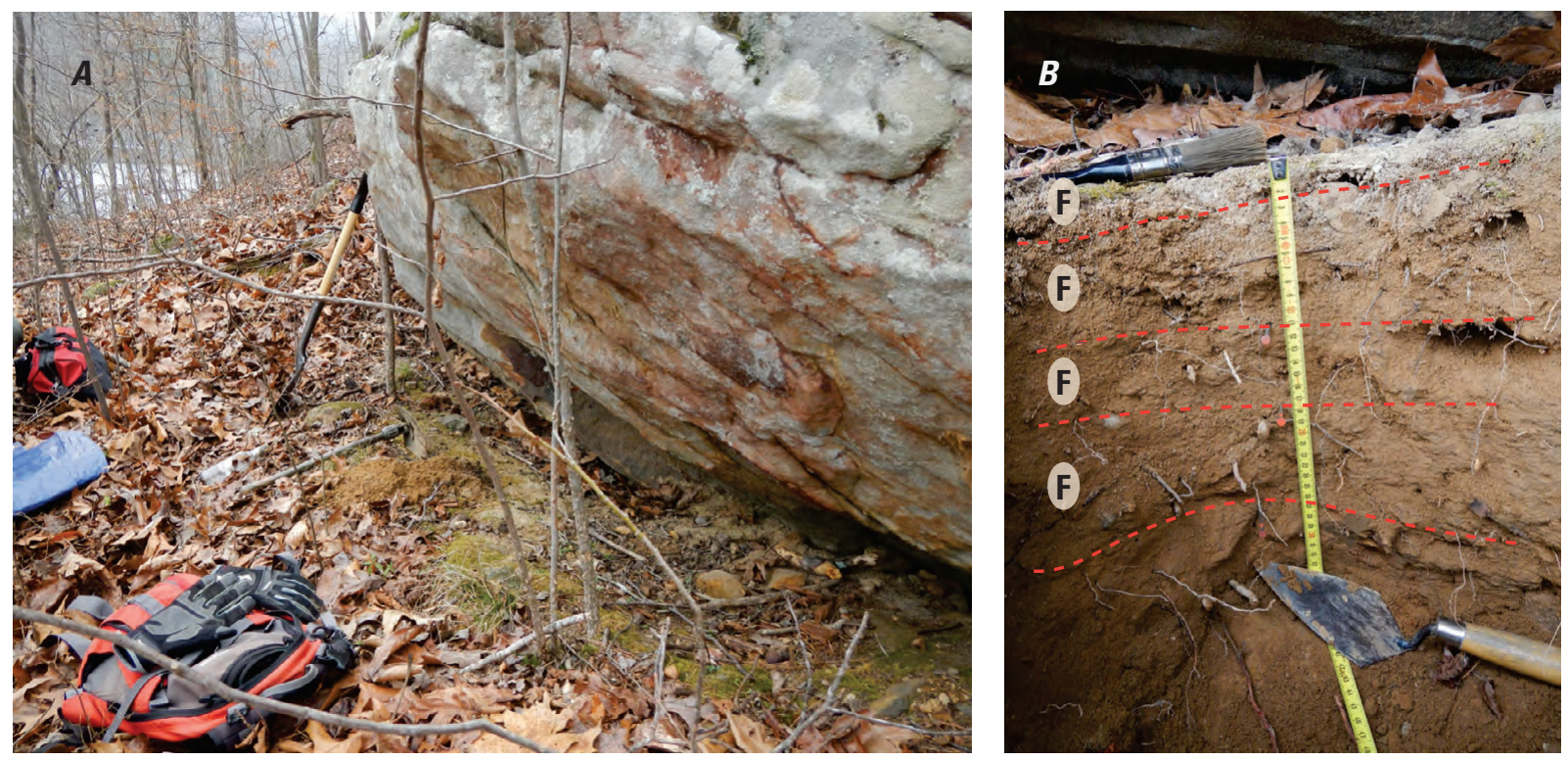

Figure 1.5. Location of the pit $(A)$ and exposed stratigraphy of the pit with four flood deposits $(B)$, at the Smirnoff site, Tennessee River, Tennessee. " $\mathrm{F}$ " indicates a flood deposit.

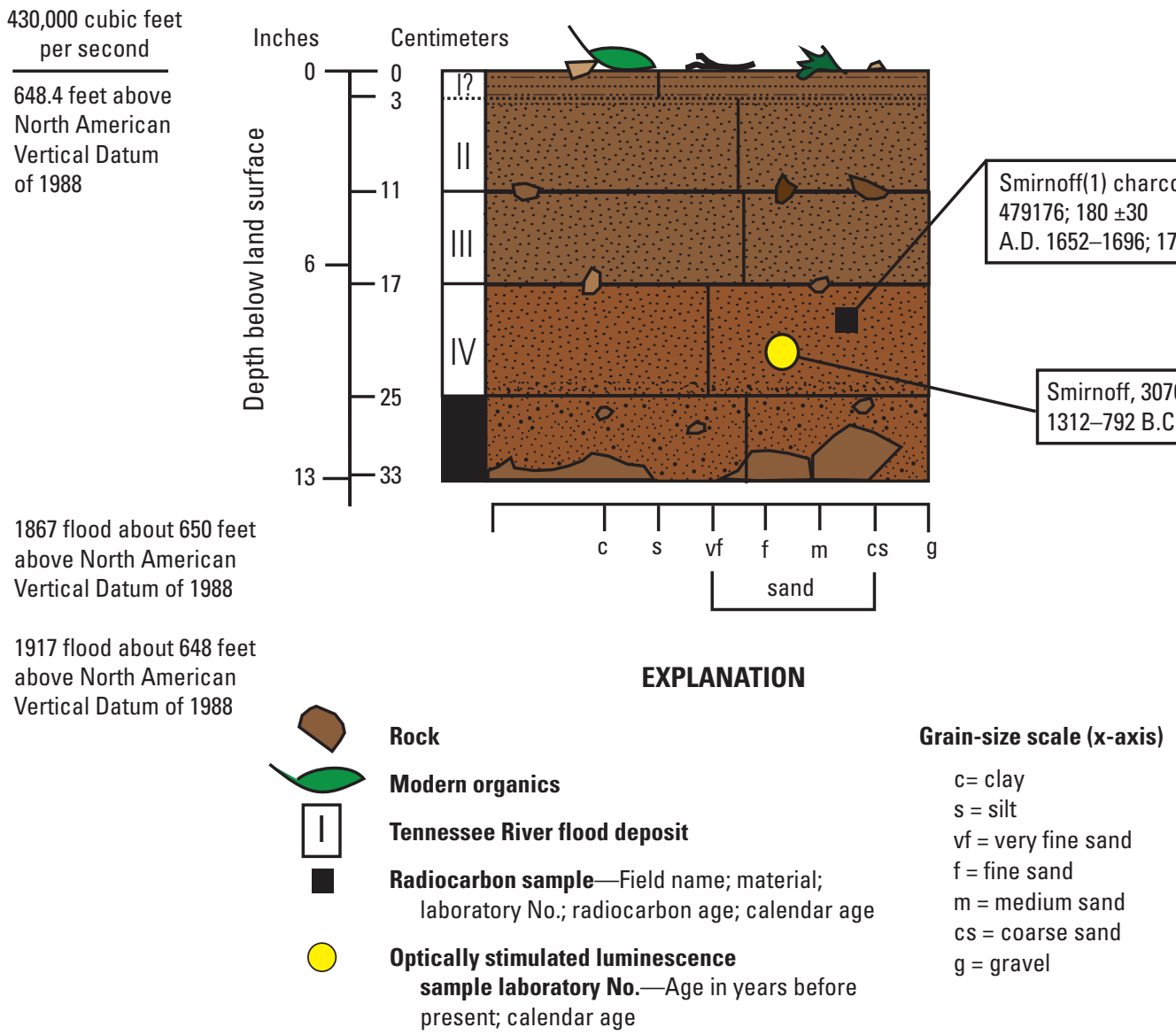

Figure 1.6. Stratigraphy exposed at the Smirnoff site, Tennessee River, Tennessee. 
Four flood deposits are evidenced at this site (fig. 1.6). The lowermost three flood deposits are separated by distinct stone lines. The contact between the upper bedded silt and the underlying very fine sand is less compelling. If these deposits represent two floods, they could be evidence of the 1917 flood (here affected by backwater from Hales Bar Dam; Tennessee Valley Authority, 1940) overlying sand deposited by the 1867 flood (fig. 10). The two older floods have more uncertainty. A piece of charcoal from $19 \mathrm{~cm}$ bls in the oldest flood deposit was radiocarbon dated at A.D. 1652-1696 and 1726-1814. An OSL sample was collected and analyzed in the same unit and returned an age of 1312-792 B.C. These dates correlate to dates of floods found at other sites, but it is difficult to know which date best represents the age of the flood deposit. If the radiocarbon date is most representative, then this flood deposit could be from the Red Flower flood. This would indicate that the sediment sampled for OSL analysis was not completely bleached prior to deposition. This scenario, however, indicates the presence of a third large flood subsequent to A.D. 1650, in addition to the Red Flower and 1867 floods. Such a finding is counter to the findings at all other sites. Another possibility is that the radiocarbon age is incorrect, and the dated charcoal was a burned root or embedded low in the sequence by burrowing. If this is the case and the OSL age is closer to the true age of the deposit, then the third oldest flood here could be evidence of the Red Flower flood. Thus, the oldest flood deposit here (1312-792 B.C. by OSL analysis) would then correlate to the oldest flood deposits found at the Jeff-n-Steph site (described in section, "Jeff-n-Steph") and the Looter Pit site (described in section, "Looter Pit").

The elevation of the water-surface of the 1867 flood was about $650 \mathrm{ft}$ above NAVD 88 at this location, which is about $1.5 \mathrm{ft}$ higher than this site (fig. 10). Additionally, backwater from the 1917 flood upstream from Hales Bar Dam had a similar stage at this site (Tennessee Valley Authority, 1940). Thus, the youngest two flood deposits are almost certainly from historical floods. This also agrees with the hydraulic modeling results, which indicate that about $430,000 \mathrm{ft}^{3} / \mathrm{s}$ is required to inundate this site for pre-impoundment conditions.

\section{Oven, Upper Oven, and Freezer}

The Oven, Freezer, and Upper Oven (fig. 1.7) are three small rock alcoves formed by a collection of sandstone boulders within close proximity to each other. Oven, the largest alcove of the three sites, is sheltered by an overhang of a several-meter-wide slab of sandstone flanked by smaller boulders that form small alcoves on the left (Upper Oven) and right (Freezer). The Oven site is a 3-by-1 m shelter about $1 \mathrm{~m}$ high at its tallest point (fig. 1.8). The surface of the site is dry, unvegetated, and covered by loose sediment, leaves, sticks, and rock fragments.

A pit was dug to a depth of $34 \mathrm{~cm}$ at the Oven site (fig. 1.9). The first $8 \mathrm{~cm}$ are tan silty very fine sand with about 10 percent subangular-to-subrounded sandstone gravel as

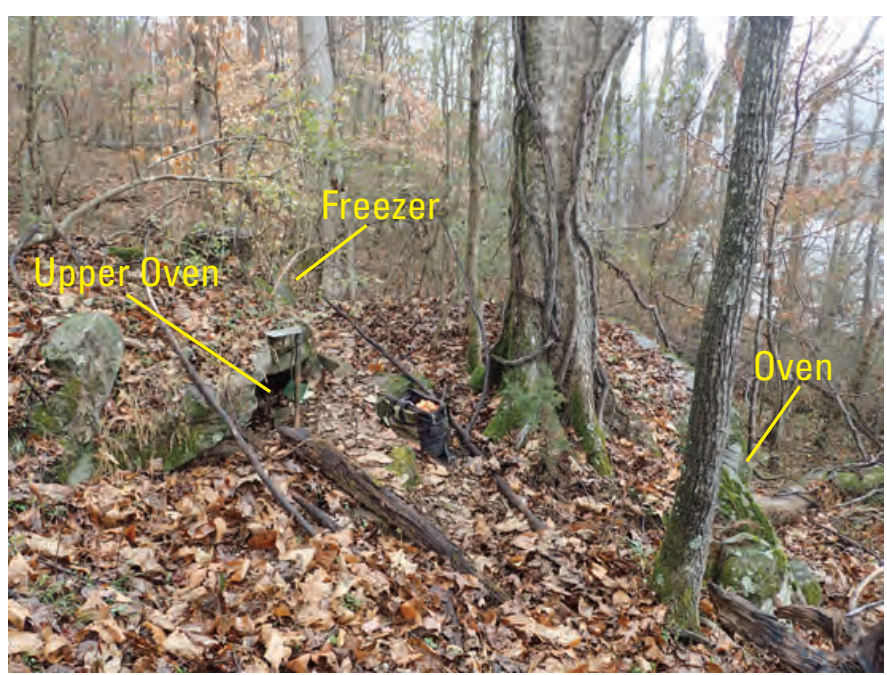

Figure 1.7. Locations of the Oven, Upper Oven, and Freezer, and Oven sites, Tennessee River, Tennessee.

much as about $2 \mathrm{~cm}$ in diameter. This unit is fairly compact, poorly sorted, and bioturbated, and has no obvious bedding. However, owing to the presence of mica and the texture, this deposit likely is a reworked flood deposit mixed with local material, and likely is part of the same silty flood deposit that can be seen plastered onto the back of the alcove.

The next two deposits are composed of relatively wellsorted, very fine to fine sand and contain coarse grains of mica. Both deposits are separated from deposits above and below by differences in texture, gravel content, and degree of sorting. A stone line of roof-fall clasts separates the two units from each other. The textures and sedimentology of the units indicate that they are flood deposits. Beneath them is oxidized orangish-brown fine sandy silt with abundant roots and deeply weathered gravel clasts, which we infer to be locally derived colluvium.

A charcoal fragment from the lowermost colluvium was radiocarbon dated to 371-199 B.C. (fig. 1.9). Above that in the oldest flood deposit, a charcoal clast returned radiocarbon date ranges of A.D. 1450-1530 and 1540-1635. This flood deposit could be from the Red Flower flood or, more likely, a smaller and slightly older flood also found at the Last Survey site (described in section, "Last Survey") and the Mud Wasp site (described in section, "Mud Wasp"). The youngest two flood deposits likely are from two historical floods, possibly 1867 and 1917 or 1875 based on the elevation of this site (fig. 10).

To the left of the Oven and a little more than $1 \mathrm{~m}$ higher in a small 1-by- $0.5 \mathrm{~m}$ alcove is the Upper Oven (figs. 1.9 and 1.10). The shallow $10-\mathrm{cm}$ pit at the Upper Oven revealed two thin very fine and well sorted sand deposits containing mica and separated from each other by a discontinuous gravel line. These two deposits were overlying rock, perhaps from the boulder that formed the Oven site. We infer that these deposits are evidence of two floods. This site was not dated because it was almost identical in stratigraphy and elevation to the Freezer site described in the paragraphs that follow. 

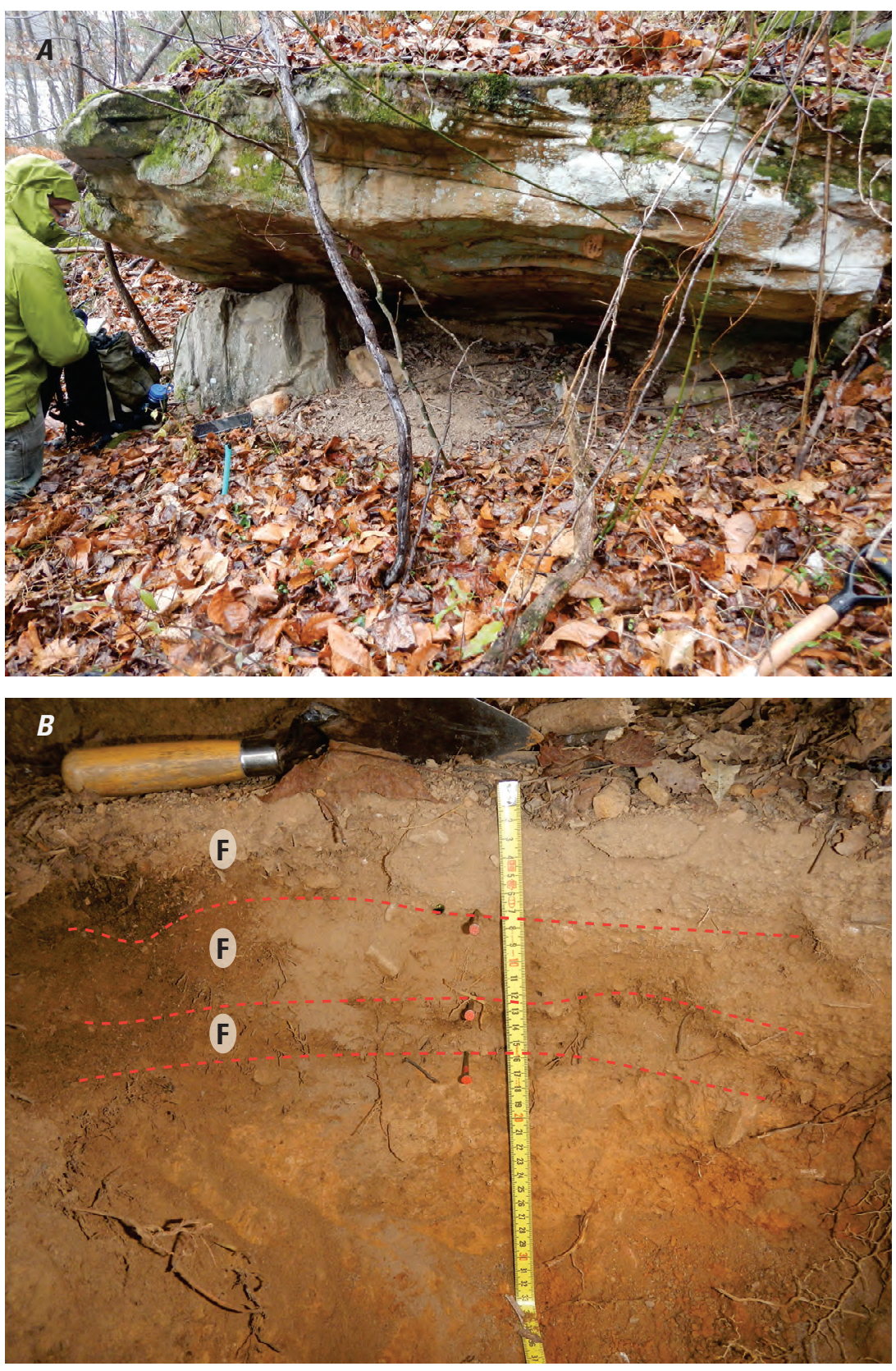

Figure 1.8. Location of the pit $(A)$ and stratigraphy exposed in the pit with four flood deposits $(B)$, at the Oven site, Tennessee River, Tennessee. " $F$ " indicates a flood deposit.

The Freezer site is at an elevation and setting similar to that of the Upper Oven site but about 3-4 $\mathrm{m}$ to the right of it (figs. 1.9 and 1.11). The stratigraphy at the Freezer site matches that of the Upper Oven site- two well-sorted micacontaining very fine sand deposits separated by a thin gravel line. The lower deposit is coarser than the upper deposit and contains visible bedding.
A piece of charcoal from the lower flood unit at the Freezer site was radiocarbon dated to A.D. 1648-1694, 1726-1813, and 1918-post-1950. Because the stratigraphy and elevation at the Upper Oven and Freezer sites were so similar, flood deposits preserved at the Freezer site almost certainly are likely from the same floods that deposited the sediment preserved in the Upper Oven stratigraphy. 
429,000 cubic feet

per second

648.31 feet above

North American

Vertical Datum

of 1988

1867 about 650 feet above

North American

Vertical Datum

of 1988

1917 about 648 feet above

North American

Vertical Datum

of 1988

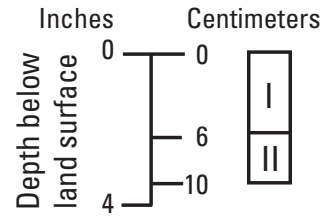

\section{Upper Oven}
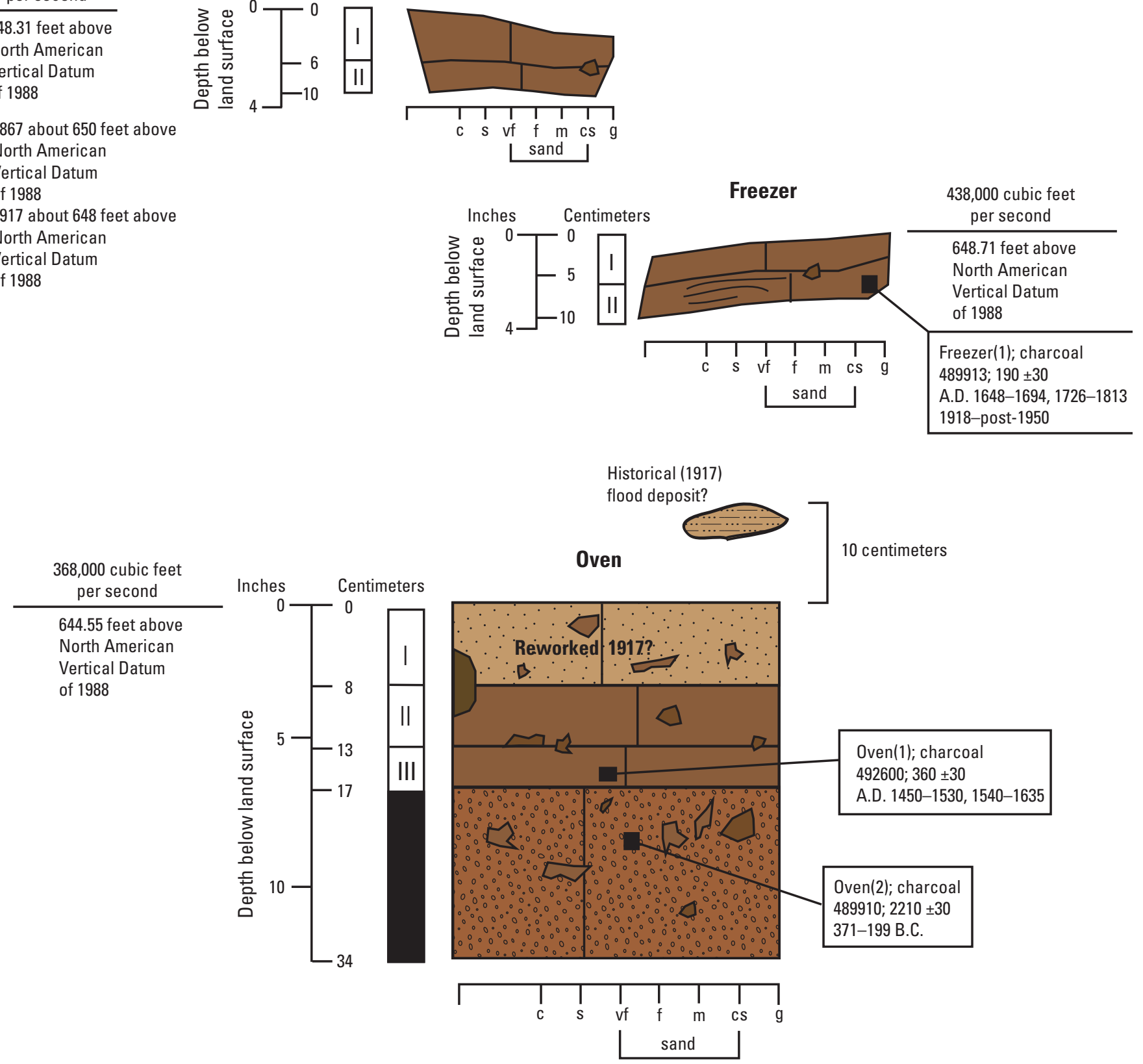

EXPLANATION

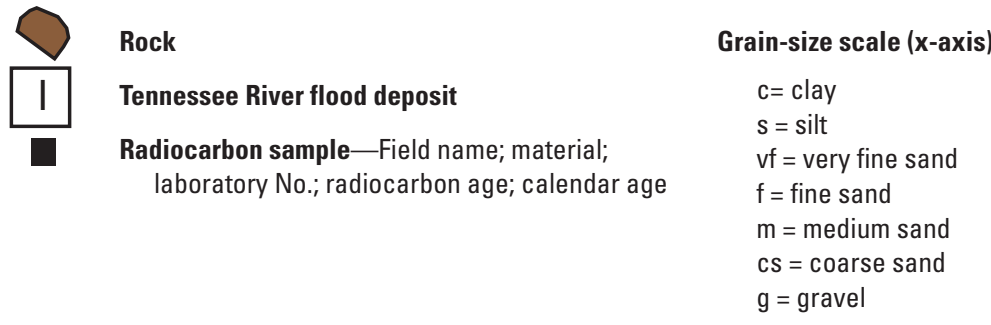

Figure 1.9. Stratigraphy at the Oven, Upper Oven, and Freezer sites including relative elevation of each pit, Tennessee River, Tennessee. 

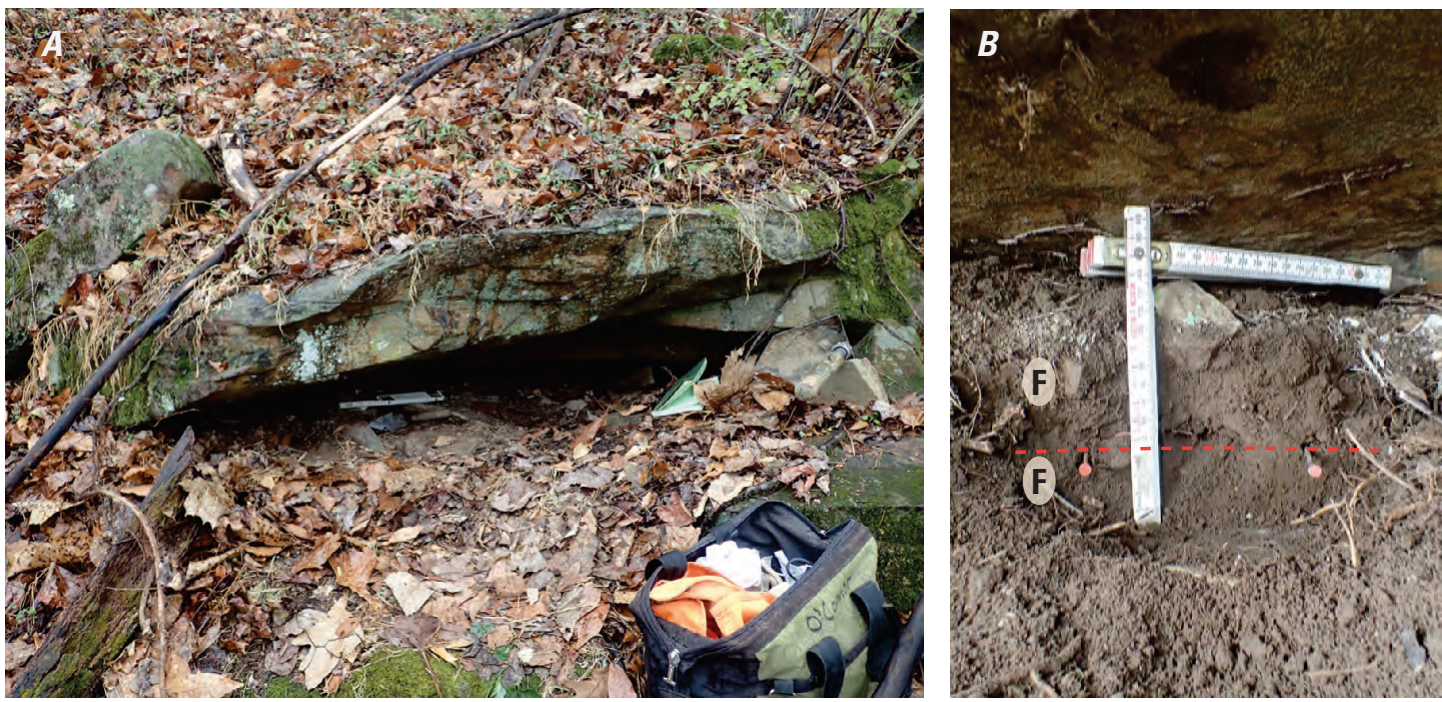

Figure 1.10. Location of the pit underneath the rock overhang $(A)$ and stratigraphy exposed in the pit $(B)$, at the Upper Oven site, Tennessee River, Tennessee. " $F$ " indicates a flood deposit.
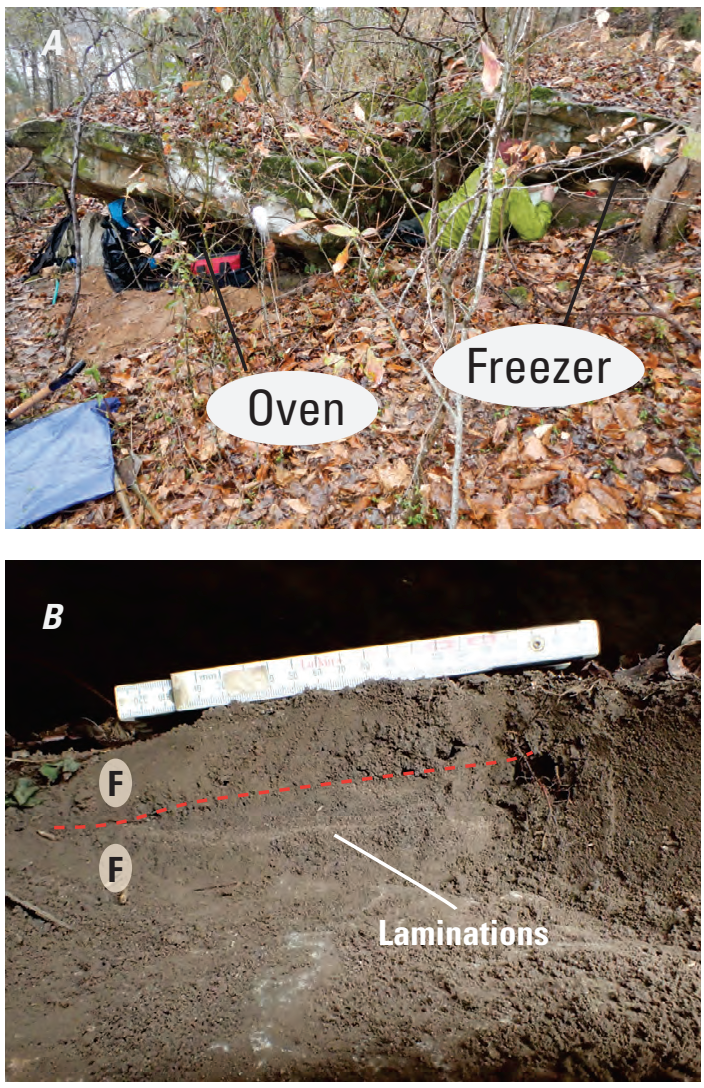

Figure 1.11. Location of the pit relative to the Oven site $(A)$ and stratigraphy exposed in the pit $(B)$, Tennessee River, Tennessee. " $F$ " indicates a flood deposit.
The elevations of the Oven, Upper Oven, and Freezer sites are $644.55 \mathrm{ft}, 648.31 \mathrm{ft}$ and $648.71 \mathrm{ft}$, respectively. The elevation of the 1867 flood at this site was about $650 \mathrm{ft}$ and likely would have inundated all three sites (fig. 10). Backwater from the 1917 flood reached an elevation of about $648 \mathrm{ft}$ possibly depositing sediment only at the Oven site. The 1875 flood (stage about $645 \mathrm{ft}$ above NAVD 88) and the $1886 \mathrm{flood}$ (stage about 644-645 ft above NAVD 88) could have inundated the Oven site as well. The hydraulic modeling indicates that the minimum discharge required to inundate the Upper Oven and Freezer sites is 430,000 and $440,000 \mathrm{ft}^{3} / \mathrm{s}$, respectively. The modeled peak discharge estimated to inundate the Oven site is considerably less, $370,000 \mathrm{ft}^{3} / \mathrm{s}$.

Based on the geochronology, stratigraphy, site elevation, and hydraulic modeling results, there is evidence of 3-4 floods preserved at this group of three sites. The silt plastered to the back of the Oven site could be from the 1917 flood. The first flood deposit exposed in the pit at the Oven site also could be reworked 1917 flood sediment, or it could be deposited from the 1867,1875 , or 1886 historical floods. The next oldest flood in the pit could be 1867 or the Red Flower flood deposit. Based on the radiocarbon dating of the oldest flood deposit at the Oven site, this flood predates the Red Flower flood and is correlated to deposits found at a few other sites such as Last Survey and Mud Wasp sites described in sections, "Last Survey" and "Mud Wasp."

The youngest flood preserved at both the Upper Oven and Freezer sites likely is the 1867 flood. Based on the radiocarbon date of the oldest flood deposit at the Freezer site, this deposit is evidence of the large Red Flower flood. 


\section{Buzzard's Cave}

The Buzzard's Cave site consists of a narrow and deep cave located along the base of a limestone outcrop near RM 455 (fig. 1.12). The cave has a 4-by-1 m opening that extends back about $16 \mathrm{~m}$ where it gets progressively narrower and higher in elevation before ending in a 1-by-1 $\mathrm{m}$ room. The floor of the cave is mostly fine-grained sediment to an unknown depth, almost certainly a combination of Tennessee River flood deposits and local cave sediment. Roof-fall boulders and bedrock form the cave floor near the entrance. Evidence of past artifact looting is evident in this cave as well as along the base of the bedrock outcrop that forms this cave. About three-quarters of the way inside the cave was a relatively undisturbed area near the cave wall where we excavated a 64-cm pit to examine the stratigraphy (fig. 1.13).

The first $3 \mathrm{~cm}$ are an indurated tannish brown very fine sandy silt cap locally draped over rock edges of the cave wall. This deposit contained sand-sized mica flakes, granules of local material, and abundant charcoal fragments but no obvious bedding. The base of this surficial layer is defined by an abrupt color change and change in gravel content. This deposit likely is evidence of the most recent Tennessee River flood deposit preserved in this cave. The next $5 \mathrm{~cm}$ below this deposit are similar, only darker in color, with smaller mica flakes and slightly higher gravel content. This deposit likely is evidence of another flood deposit. Below these flood deposits are $8 \mathrm{~cm}$ of brown very fine sandy silt with a gravel content of about 20 percent, mostly rounded as much as $1 \mathrm{~cm}$ in diameter but some angular clasts as much as $3 \mathrm{~cm}$. This deposit contains small shell fragments and other bits of organic material and likely represents a bioturbated cave floor deposit.

From 16 to $35 \mathrm{~cm}$ in depth is brown silt with some sand. This deposit discontinues or thins substantially towards the back of the cave. A few angular gravel clasts were present but at quantities significantly less than the deposits above and below. Organic material is sparse. This deposit likely is evidence of a third Tennessee River flood deposit preserved at this site. Below this flood deposit to a depth of $53 \mathrm{~cm}$ is brown very fine sandy silt with abundant subrounded to angular gravel as much as $5 \mathrm{~cm}$ in diameter. This deposit contains specks of charcoal and other organics and is interpreted as representing a previous cave floor deposit. The basal deposit partially exposed at this site is an 11-cm thick brown silty very fine sand with visible mica, few angular clasts, and no visible bedding. This deposit is better sorted with less gravel than the deposit above and likely is evidence of a fourth Tennessee River flood deposit.

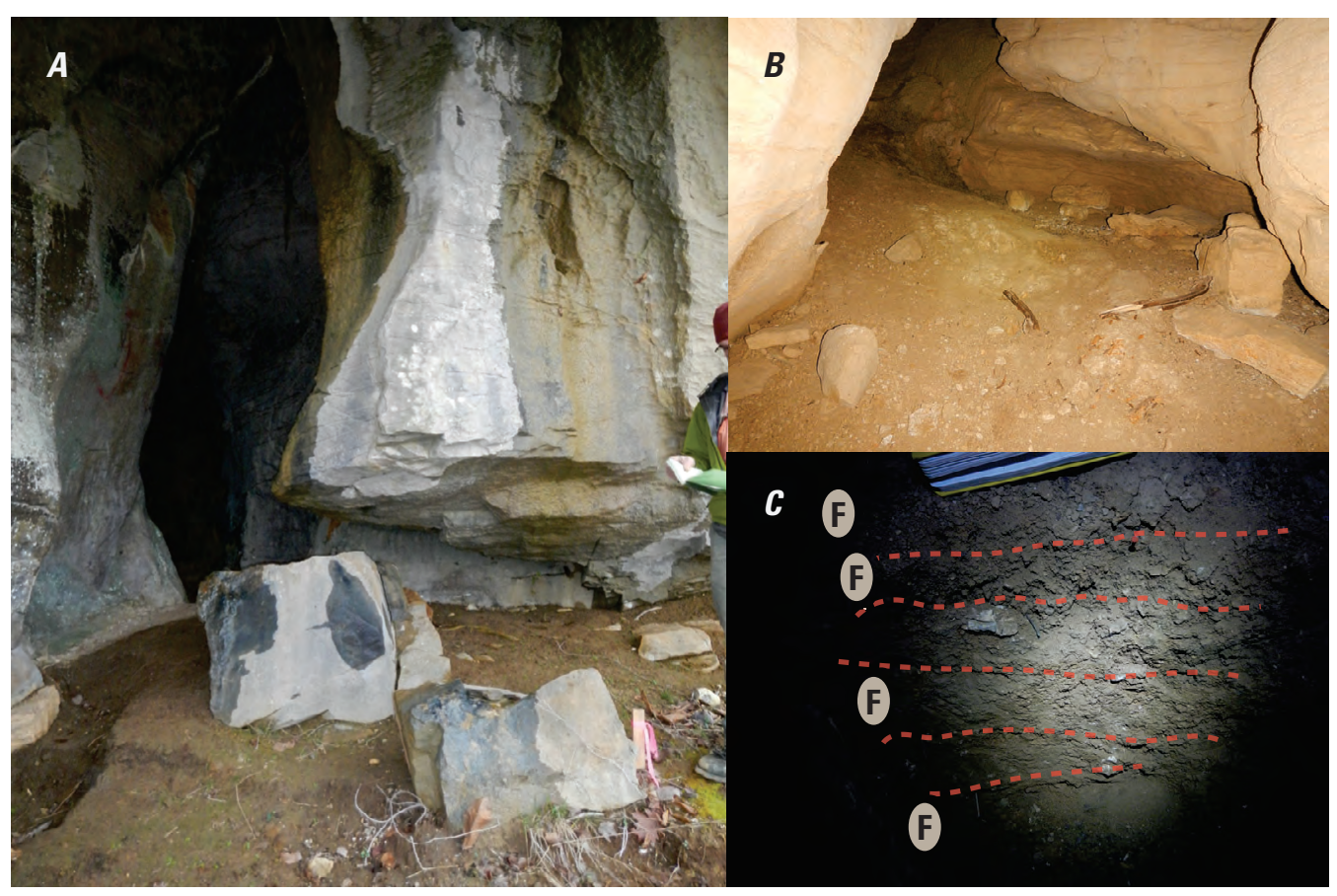

Figure 1.12. Cave entrance $(A)$, location of the pit inside the cave $(B)$, and stratigraphy exposed in the pit $(C)$, at the Buzzard's Cave site, Tennessee River, Tennessee. "F" indicates a flood deposit. 


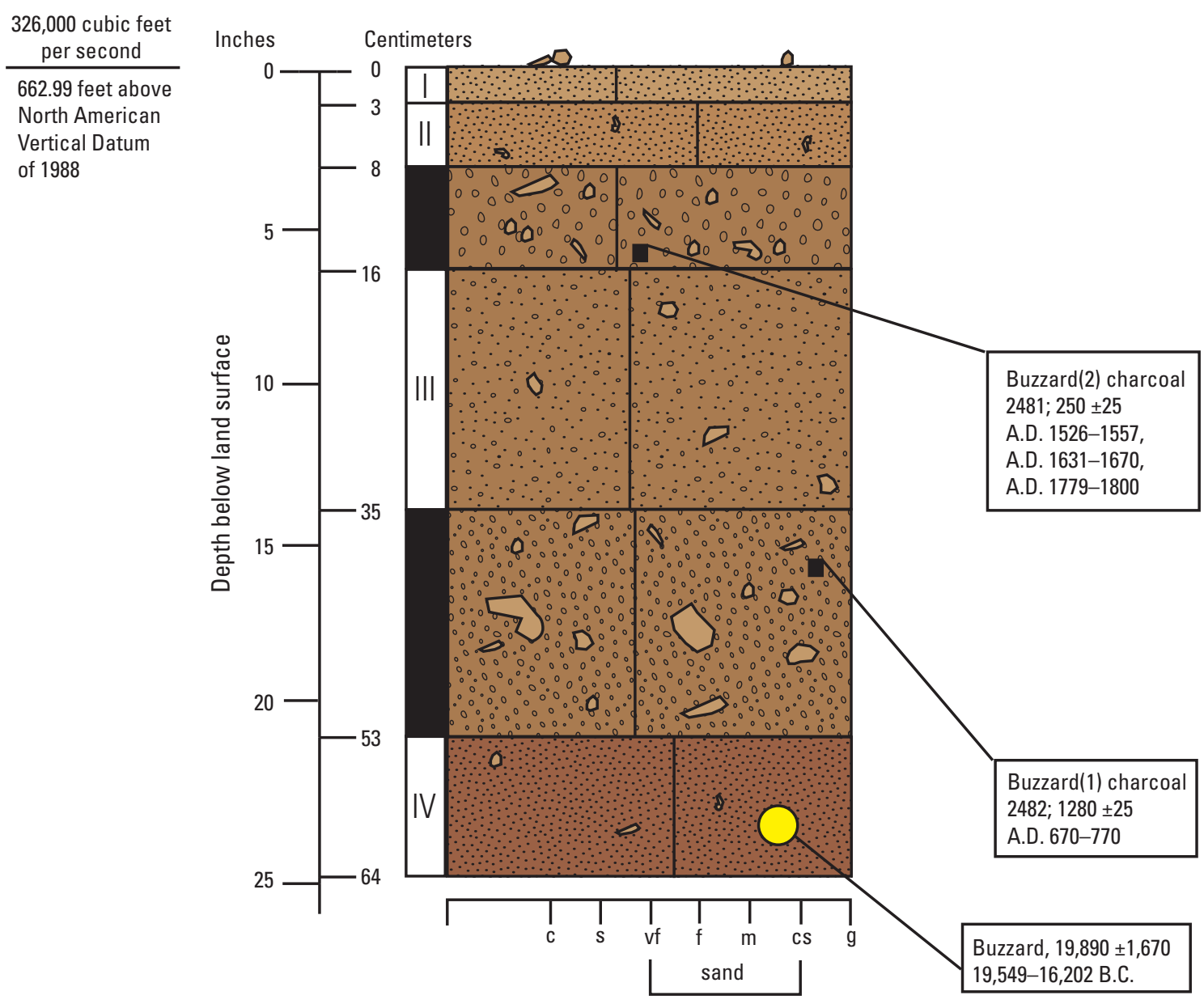

EXPLANATION

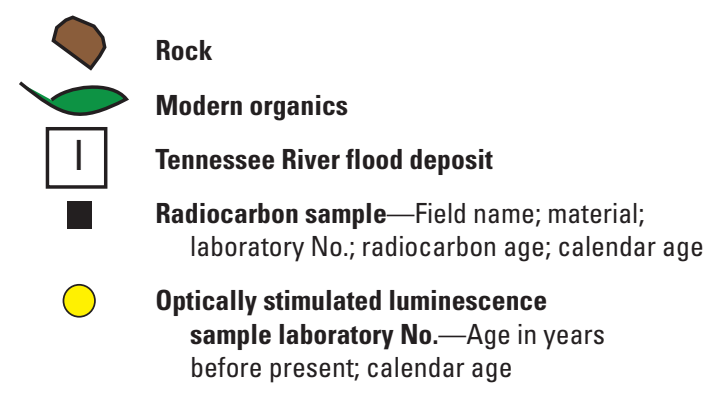

$$
\begin{aligned}
& \text { Grain-size scale ( } \mathrm{x} \text {-axis) } \\
& \begin{array}{l}
\mathrm{c}=\text { clay } \\
\mathrm{s}=\text { silt } \\
\mathrm{vf}=\text { very fine sand } \\
\mathrm{f}=\text { fine sand } \\
\mathrm{m}=\text { medium sand } \\
\mathrm{cs}=\text { coarse sand } \\
\mathrm{g}=\text { gravel }
\end{array}
\end{aligned}
$$

before present; calendar age

Figure 1.13. Stratigraphy at the Buzzard's Cave site, Tennessee River, Tennessee.

An OSL sample from the oldest flood deposit exposed at this site returned a date range of 19,549-16,202 B.C. A piece of charcoal from the colluvium unit above was radiocarbon dated to A.D. 670-770. If both dates accurately date the deposits in which they were found, less than $20 \mathrm{~cm}$ of sediment were deposited in the last approximately 19,000 years compared to about $30 \mathrm{~cm}$ plus in the last approximately 1,200 years. This scenario is highly unlikely. The setting at this site is in a cave, a very passive setting, so erosion from floodwaters also is highly unlikely. What seems most likely is that the quartz grains in the OSL were not completely bleached during the flood that deposited them in the cave and, therefore, the OSL age indicates that last time they were completely bleached and not when they were last deposited by a flood. This can occur if the flood occurred at night or if the flood waters were turbid. Both options are plausible for Tennessee River floods. Therefore, the oldest flood at this site is older than about A.D. 670-770 and could be the same flood as either the oldest or second oldest flood preserved at the Jeff-n-Steph site, or the oldest flood at the Looter Pit and Smirnoff sites. 
The age of the third oldest flood at this site is bracketed between the underlying A.D. 670-770 cave flood deposit and the overlying cave floor deposit dated to A.D. 1526-1557, 1631-1670, and A.D. 1779-1800. Although the exact age of the flood is unknown, it occurred between the two radiocarbon dates and could correspond to the Red Flower flood or the slightly older flood preserved at the Oven and Last Survey sites and the Mud Wasp. The two youngest floods at this site post-date about A.D. 1800. Considering the elevation of this site $(662.99 \mathrm{ft}$ compared to about $675 \mathrm{ft}$ at this location for the 1867 flood), these younger flood deposits are almost certainly from two historical floods, possibly from 1867 and 1875 (fig. 10). Discharge required to inundate this site is $330,000 \mathrm{ft}^{3} / \mathrm{s}$.

\section{Mud Wasp}

The Mud Wasp site is located at the base of a limestone outcrop (fig. 1.14) about $30 \mathrm{~m}$ downstream from the opening to Buzzard's Cave (fig. 10). A 48-cm pit at this site indicated multiple deposits with similar textures ranging from tan silty very fine sand at the top unit to dark brown silty fine sand for the basal deposit (fig. 1.15). These deposits are separated from each other based on color and modest texture differences.
Some deposits had laminated silt caps as well as visible stone lines and dark stains that appear to be thin alcove floor deposits. Mica is present throughout the deposits but varies in abundance and grain size. Based on the stratigraphy at this site, we infer that seven distinct Tennessee River flood deposits are preserved here (fig. 1.15).

At $651.83 \mathrm{ft}$ above NAVD 88, the Mud Wasp site is about $2 \mathrm{ft}$ lower than the stage for the 1936 flood $\left(234,000 \mathrm{ft}^{3} / \mathrm{s}\right.$ as reconstructed for this reach by the Tennessee Valley Authority, 1940). Discharge required to inundate this site is $220,000 \mathrm{ft}^{3} / \mathrm{s}$.

A charcoal sample was collected from $48 \mathrm{~cm}$ bls in the oldest flood deposit and sent for radiocarbon analysis. The results indicate that the oldest flood at this site occurred about A.D. 770-941 (table 2); therefore, the six younger floods must have occurred in that last 800-900 years. An OSL sample was collected from $28 \mathrm{~cm}$ bls in the fourth oldest deposit and returned an age of A.D. 1588-1648 (table 3), an age similar to the oldest flood at the Oven and Last Survey sites. Based on these dates, this site contains evidence of four floods from about A.D. 770 to 1649 and three floods younger than about A.D. 1648. Because this site is so low in elevation, the three youngest floods could be documented historical floods, floods recorded in the gaged record, or historical-era floods of lesser magnitude that did not warrant documentation.
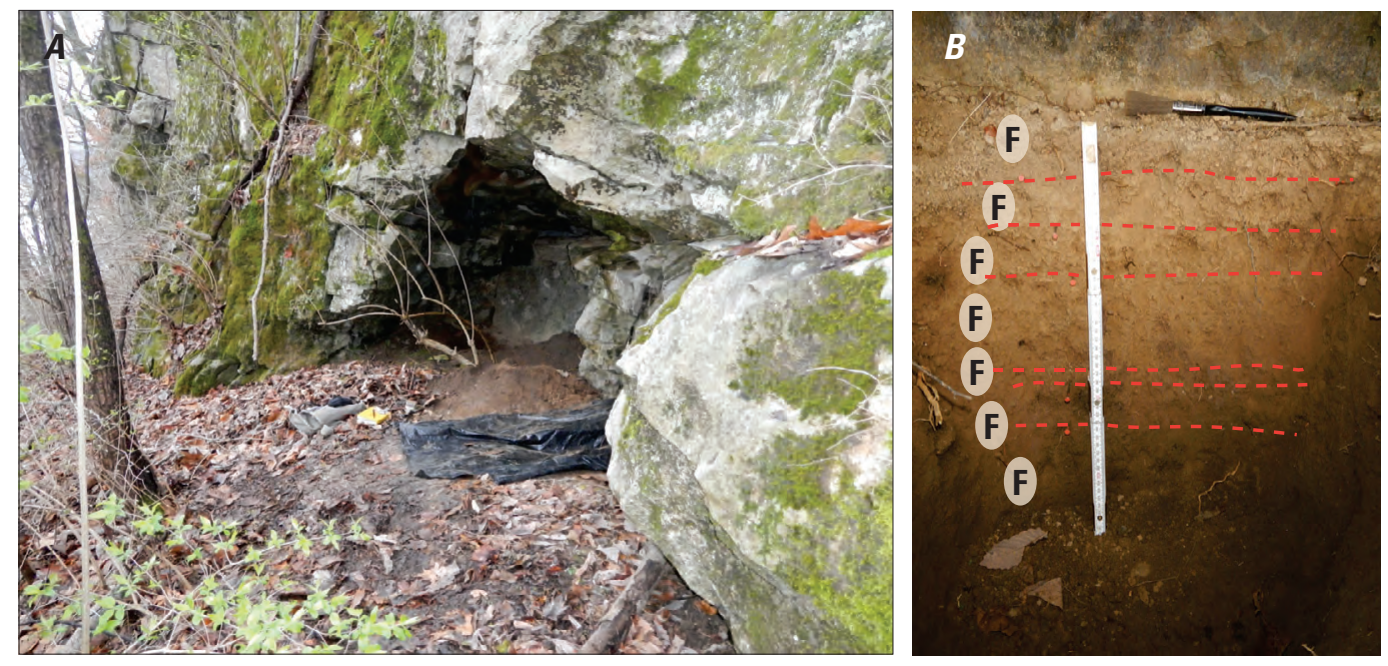

Figure 1.14. Location of the pit $(A)$ and stratigraphy exposed in the pit $(B)$, at the Mud Wasp site, Tennessee River, Tennessee. "F" indicates a flood deposit. 


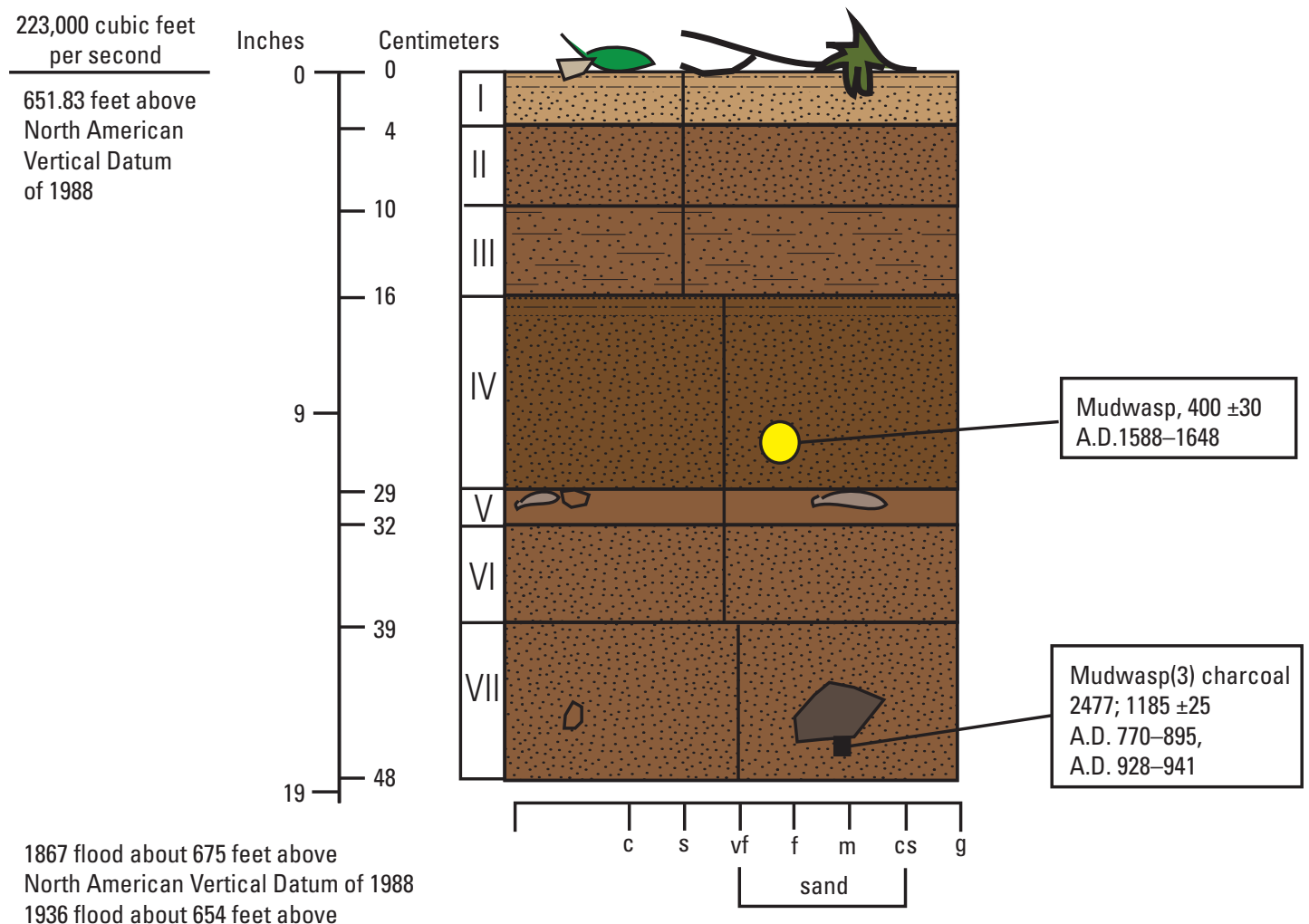

North American Vertical Datum of 1988

EXPLANATION

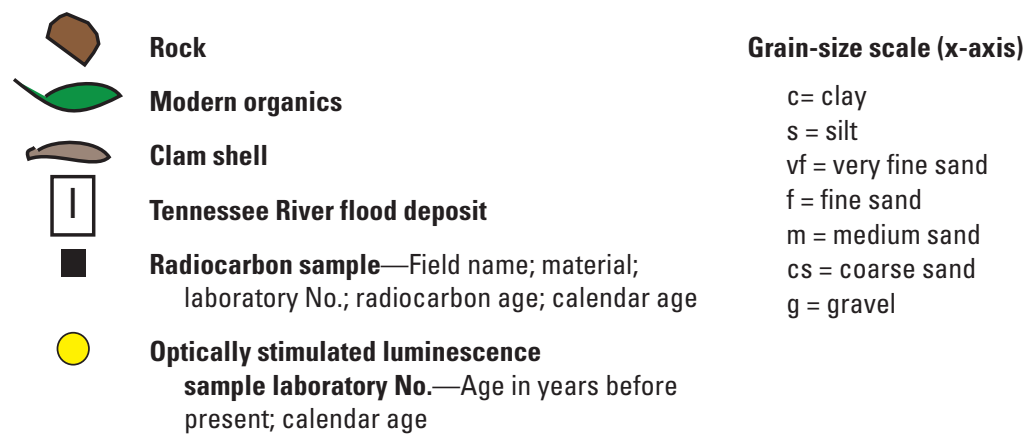

Figure 1.15. Stratigraphy of the Mud Wasp site, Tennessee River, Tennessee. All deposits at this site are evidence of Tennessee River floods.

\section{Looter Pit}

About halfway between the entrance to Buzzard's Cave and the Mud Wasp site along the base of a limestone outcrop is the Looter Pit site (fig. 1.16). An 87-cm pit was dug at this site (fig. 1.17). The top $6 \mathrm{~cm}$ are weakly laminated tan silt containing small flakes of mica. Below this deposit is a 13-cm-thick dark brown very fine sandy silt (with a few limestone granules as much as $3 \mathrm{~mm}$ ) that is separated from the deposit below by a line of angular gravel clasts as much as $3 \mathrm{~cm}$ in diameter. At a depth of 19-27 cm lies brown very fine sandy silt. This deposit is well sorted but the top has several subrounded gravel clasts as much as $2 \mathrm{~cm}$ in diameter. Below this layer is $19 \mathrm{~cm}(27-46 \mathrm{~cm})$ of well sorted orangish-brown very fine sandy silt. Based on the textures and sorting, we infer that these top 4 deposits are Tennessee River flood deposits. These deposits overlie a brown, 10-cm-thick poorly sorted sandy silt deposit with abundant charcoal and gravel clasts as much as $5 \mathrm{~cm}$ in diameter. This deposit is either local material or a mixture of local material and reworked flood deposits from the unit below and extends to a depth of $56 \mathrm{~cm}$. Below this deposit to a depth of $69 \mathrm{~cm}$ is another flood deposit with characteristics similar to those of the flood deposits from 27 to $46 \mathrm{~cm}$. The basal unit (69-87 cm bls) in this pit is another poorly sorted, gravel-rich, alcove floor deposit. Based on the stratigraphy, we infer that this site contains evidence of five floods and two alcove floor deposits (fig. 1.17). 

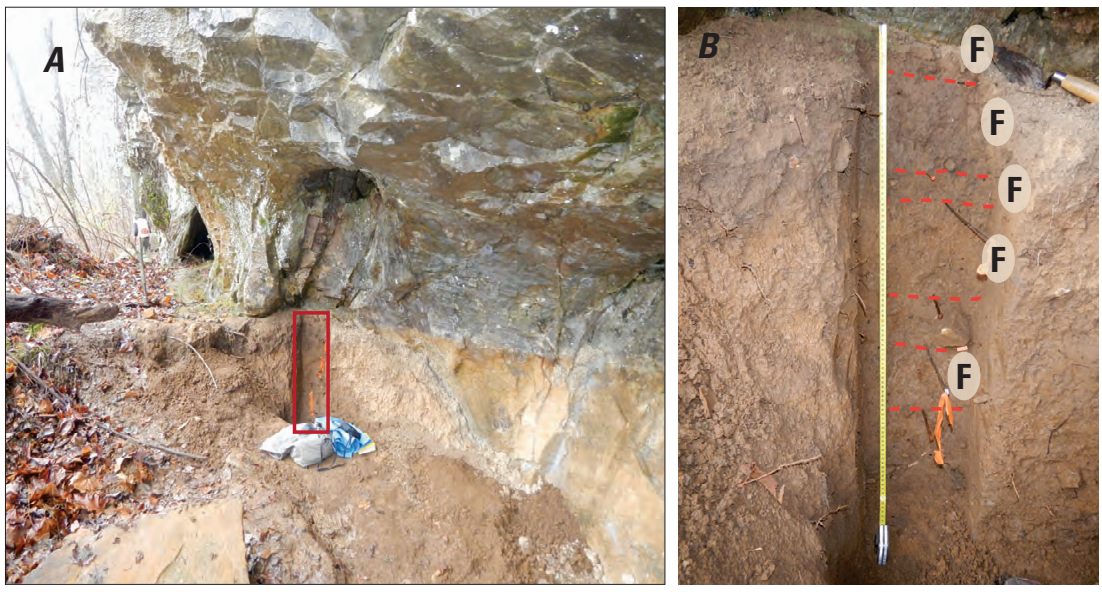

Figure 1.16. Location of the sediment exposure $(A)$ and stratigraphy $(B)$, at the Looter Pit site, Tennessee River, Tennessee. "F" indicates a flood deposit.

A piece of charcoal from $73 \mathrm{~cm}$ in depth in the oldest exposed deposit was dated to 3516-3363 B.C. (fig. 1.17). Charcoal from the flood deposit above this alcove floor deposit was radiocarbon dated to 1121-940 B.C. The next oldest flood deposit was dated to 931-822 B.C. Based on the radiocarbon ages, these two flood deposits likely are evidence of one flood likely the same as the oldest flood at Jeff-n-Steph and one unique Tennessee River flood not previously described in this report. Like the Mud Wasp site, the Looter Pit site is relatively low, with an elevation of $653.47 \mathrm{ft}$ and requires a discharge of about $240,000 \mathrm{ft}^{3} / \mathrm{s}$ to inundate the site. The magnitude required to inundate this site and leave a deposit is relatively small and well represented in the gaged record. The three younger floods preserved here most likely correspond to any number of floods at other sites including any of the large historical floods such as the 1867,1875 or 1886 floods (fig. 10).

\section{Turkey Blind}

The Turkey Blind site is located on the left bank at the most downstream exposure of a limestone outcrop near the entrance to the gorge at about RM 454 (figs. 2 and 10). This site is in a narrow cave about $5 \mathrm{~m}$ above a 75 -m-wide low terrace used for agriculture. The opening to the cave is about 1-by- $1 \mathrm{~m}$ and narrows to 0.5 -by- $0.25 \mathrm{~m}$ about $4-5 \mathrm{~m}$ back from the entrance (fig. 1.18). A $28-\mathrm{cm}$ pit exposed the stratigraphy about $3 \mathrm{~m}$ from the entrance to the cave at a junction between the main cave and a small crevice in the left (upstream) side of a limestone wall. The location of the pit was selected because of the decreased likelihood of bioturbation from rodents and other animals that may have inhabited the cave at various times.
The top surface of the cave deposits near the pit appeared to be weathered mud cracks, a feature that forms after water recedes and fine-grained sediments separate as they dry to form desiccation cracks with a recognizable geometry. Excavation of the pit indicated multiple discernable deposits (fig. 1.19). The top $5 \mathrm{~cm}$ of gray mottled silt, including the mud cracks, was indurated, had hints of discontinuous wavy laminae, and contained mica. The lower contact was sharp and marked by a change in texture and color. Below this deposit was a brown, crumbly silt that was locally loose. This deposit contained limestone granules, gravel clasts, roots, and small rodent bones. This likely was a cave floor deposit buried by the flood deposit above. Below this deposit was a thin tan silt that varied $0-2 \mathrm{~cm}$ in thickness. This deposit contained mica but no obvious bedding. Based on the color, lack of gravel and granules, and the presence of mica grains, this likely was a Tennessee River flood deposit. Another dark brown crumbly gravel-rich silty cave floor deposit separated the thin flood deposit above from a dull orange silty fine mica containing sand, likely representing another flood deposit below. The bottom of this deposit was not exposed.

A small piece of charcoal within the cave floor deposit just above the oldest flood deposit was radiocarbon dated to A.D. $1458-1530$ and A.D. $1538-1635$ (fig. 1.19). The two floods above this deposit must post-date this age and the flood deposit below must precede it. The Tennessee Valley Authority (1940) reconstruction of water-surface elevation of the 1867 flood (fig. 10) was about $674 \mathrm{ft}$ at this site, slightly above the surveyed elevation of $672.8 \mathrm{ft}$ for the surface of the exposed pit. The hydraulic model estimates that about 450,000 $\mathrm{ft}^{3} / \mathrm{s}$ is required for inundation. Therefore, the youngest flood deposit likely is that of the 1867 flood. The second oldest flood deposit could be evidence of the Red Flower flood. The oldest flood deposit could be from one of the older floods found at Jeff-n-Steph. 


\begin{tabular}{l}
$\begin{array}{l}236,000 \text { cubic feet } \\
\text { per second }\end{array}$ \\
\hline 653.47 feet above \\
North American \\
Vertical Datum \\
of 1988
\end{tabular}

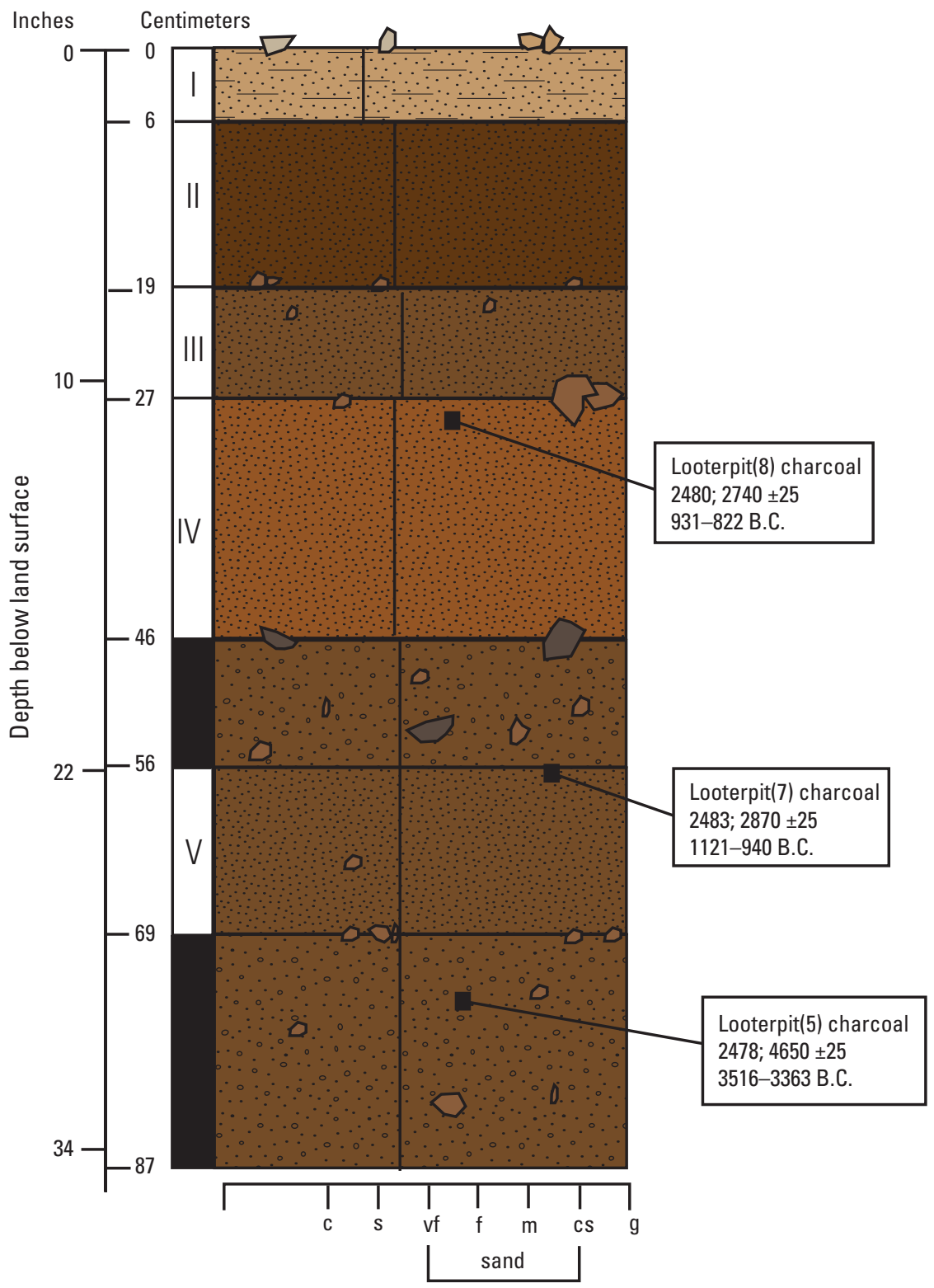

EXPLANATION

\begin{tabular}{|lll}
\hline & Rock & Size scale (x-axis) \\
\hline I & Tennessee River flood deposit & $\mathrm{c}=$ clay \\
Radiocarbon sample_Field name; material; & $\mathrm{s}=$ silt \\
laboratory No.; radiocarbon age; calendar age & $\mathrm{vf}=$ very fine sand \\
& $\mathrm{f}=$ fine sand \\
& $\mathrm{m}=$ medium sand \\
& $\mathrm{cs}=$ coarse sand \\
& $\mathrm{g}=$ gravel
\end{tabular}

Figure 1.17. Stratigraphy of the Looter Pit site, Tennessee River, Tennessee. 


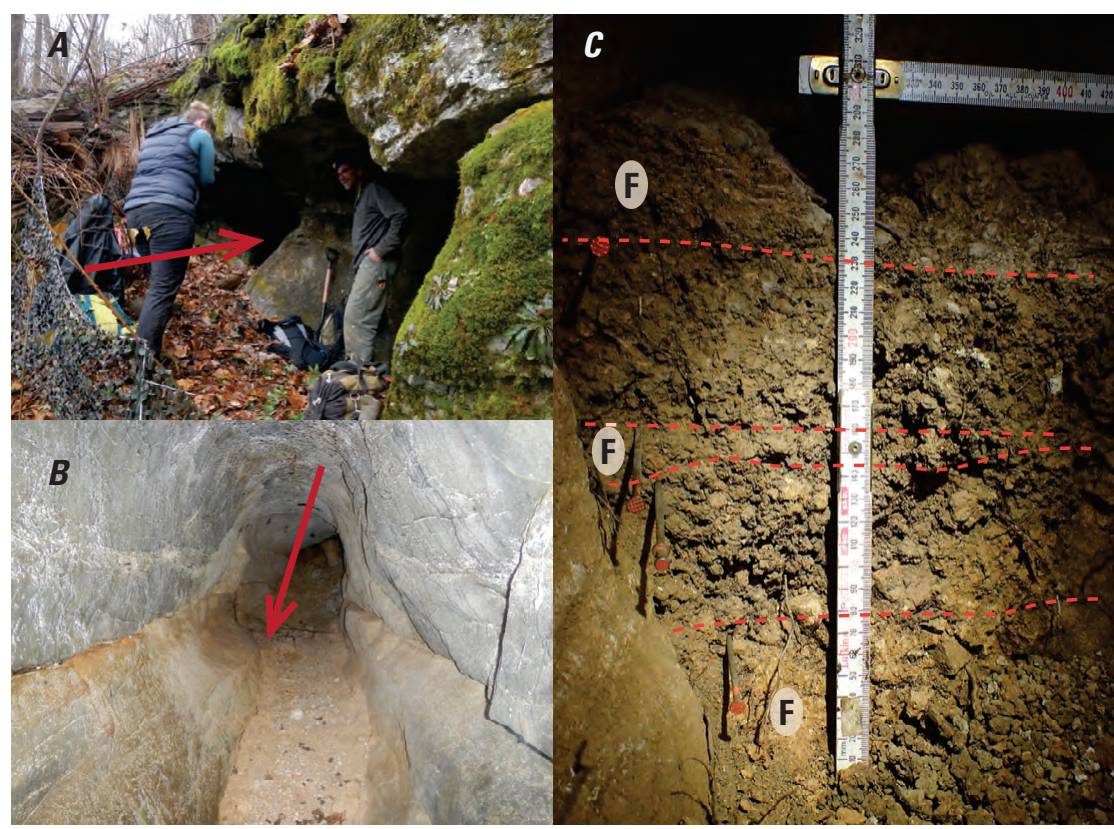

Figure 1.18. Entrance to the cave where the pit was dug $(A)$, location of the pit inside the cave $(B)$, and the stratigraphy exposed in the pit $(C)$, Tennessee River, Tennessee. " $\mathrm{F}$ " indicates a flood deposit.

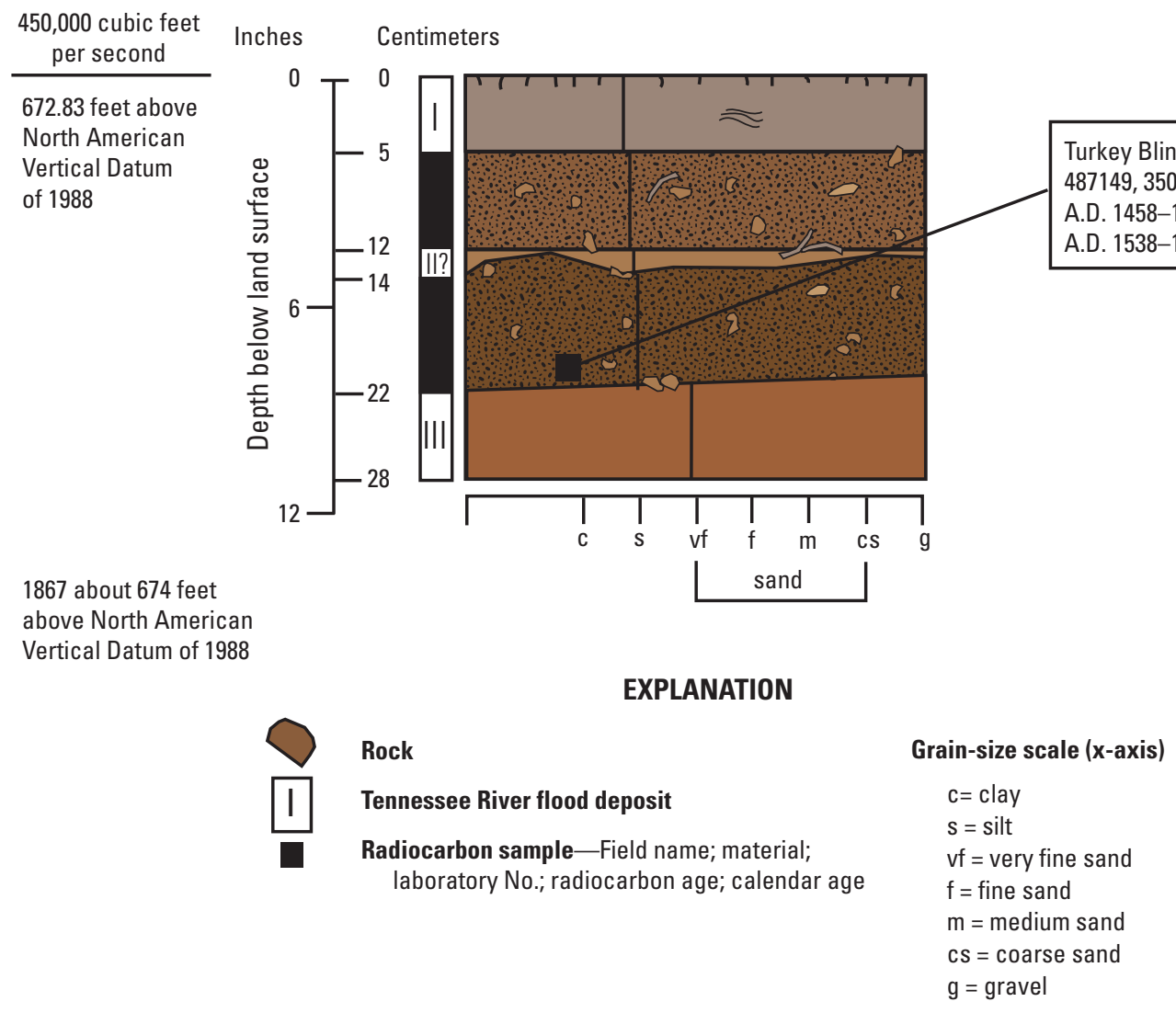

Figure 1.19. Stratigraphy at the Turkey Blind site, Tennessee River, Tennessee. 


\section{Williams Island}

Williams Island, directly across a side channel from the Buzzard's Cave, Mud Wasp, and Looter Pit sites, is a 3-kmlong, $1-\mathrm{km}^{2}$ alluvial island at the entrance of the Tennessee River Gorge (fig. 2) at about RM 457. Williams Island likely was formed as a sand bar that was stabilized by vegetation, eventually growing taller by vertical accretion of overbank flood deposits. Now owned by the State of Tennessee Division of Archeology and managed by the Tennessee River Trust, Williams Island was formed more than 10,000 years ago (Petticord, 2013; Harden and O'Connor, 2017). Examination of the stratigraphy of the island indicates a long history of fluvial activity.

The northwestern side of Williams Island is tallest, rising 8-9 $\mathrm{m}$ above the water surface of the main channel of the Tennessee River. Here, the stratigraphy is exposed in a vertical bank cut (fig. 1.20). The elevation of the top of the bank cut is $661.28 \mathrm{ft}$ compared to about $634 \mathrm{ft}$ for the water surface. The surface of this island has been inundated several times since $1867 ; 310,000 \mathrm{ft}^{3} / \mathrm{s}$ is required to inundate this island. As part of the feasibility study (Harden and O'Connor, 2017), an OSL sample was collected at $652.66 \mathrm{ft}$ above NAVD 88 (about $2.7 \mathrm{~m}$ bls) and returned a date range of 10,840-8,960 B.C. Because this study is focused on the last few thousand years, we reexamined the stratigraphy in 2018 , focusing on the upper few meters.

The top $4.3 \mathrm{~m}$ of stratigraphy of the bank exposure at RM 455 was examined and described in detail (fig. 1.21). The top $15 \mathrm{~cm}$ bls of the exposure is a root mat that hangs out over the section by about $30 \mathrm{~cm}$. The matrix is dark brown silty sand and the deposit is capped by a bed of leaves and other vegetation. The roots in this layer are as much as $10 \mathrm{~cm}$ in diameter. This clearly is an organic rich soil horizon developed in overbank sands. The next deposit is $38 \mathrm{~cm}$ of dark brownishgray silty very fine sand. There is abundant mica but no visible sedimentary structures. This deposit has been extensively burrowed and has abundant roots as much as $3 \mathrm{~cm}$ in diameter. This deposit represents overbank sands possibly deposited by multiple floods because it is so thick, although there are no visible stratigraphic boundaries. The deposit below (53-65 $\mathrm{cm}$ ) is a tan-to-gray well-sorted fine sand with abundant coarse mica grains. This deposit contains hints of local planar bedding and is less consolidated than the underlying and overlying deposits. It forms a distinct layer in the whole island exposure, almost certainly evidence of a single overbank deposit from a large, energetic flood. Below $65 \mathrm{~cm}$ in depth lies 18 $\mathrm{cm}$ of light orange silty very fine sand. This deposit has sparse small mica grains and abundant charcoal fragments as much as $1 \mathrm{~mm}$ in diameter. There are multiple small burrows as much as about $1 \mathrm{~cm}$ in diameter that have obscured any bedding features. It is uncertain if this is evidence of one oxidized, muddy overbank flood deposit or multiple flood deposits.

Below $83 \mathrm{~cm}$, the deposits are more poorly sorted owing to the introduction of non-fluvial material through occupation of the site. From 83 to $87 \mathrm{~cm}$, the deposit is poorly sorted silty fine sand with small mica flakes, abundant small charcoal fragments, and wavy laminae. This could represent a flood sand overlying a surface previously occupied by humans or it could be the basal sand associated with the finer overbank deposit above. Below this unit are two similar deposits that were extensively occupied by humans for what seems to be an extended time period. Both deposits have about 5-10 percent angular to rounded gravel as much as $5 \mathrm{~cm}$ in diameter, abundant charcoal and mica, no visible bedding, and abundant burrows. The older of the two deposits at 115-140 $\mathrm{cm}$ in depth weathers to a strong angular or blocky texture and has distinct orange-to-purple mottling (fig. 1.20D). This unit seems to be an extensively occupied, bioturbated, and pedogenically altered surface formed in silty overbank deposits.

Underlying these occupation surfaces are a few meters of fine-grained overbank deposits intermixed with coarsergrained energetic flood deposits likely indicating larger floods (fig. 1.20E). A thick silty very fine sand unit at $154-212 \mathrm{~cm}$ in depth has been so pedogenically modified that it has more soil characteristics than fluvial characteristics, likely indicating subaerial exposure for an extended period of time, during a relatively long quiescent period between large Tennessee River floods.

Because Williams Island accreted over many thousands of years, most of the sediments are overbank deposits from the Tennessee River. Although the stratigraphy at this site comes from a common source, the units vary in color, texture, and thickness (fig. 1.21), depending on various characteristics of the flood such as velocity and duration as well as local influences such as exposure to the surface and introduction and amount of non-fluvially derived material. Non-fluvially derived material includes organic material from island vegetation and material introduced by human occupation.

Three charcoal fragments from 60,86 , and $120 \mathrm{~cm}$ bls (fig. 1.21) were sent for radiocarbon analysis. The charcoal at $60 \mathrm{~cm}$ was from the youngest energetic flood deposit described earlier in this section and returned date ranges of 2458-2269 and 2260-2207 B.C. This energetic flood could be the same one as the oldest flood at Jeff-n-Steph. Considering how charcoal-rich were some of the older overbank deposits below this unit, the charcoal in this unit could be reworked from the older charcoal-rich occupied units, meaning this flood is younger than the radiocarbon age of the organic material. If this is true, then based on the coarseness of the grains and its stratigraphic position, this unit could possibly also be evidence of the Red Flower flood. 


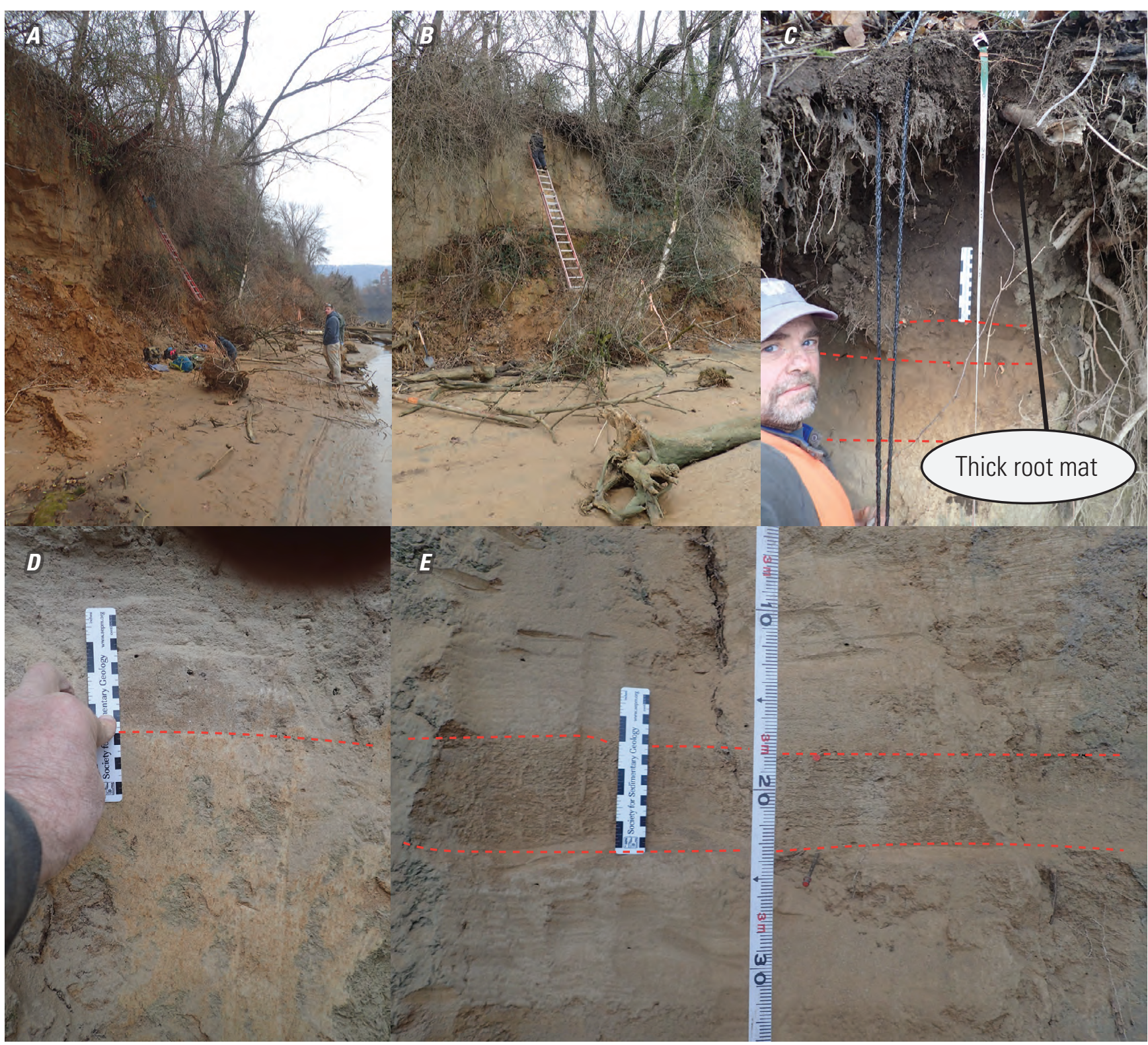

Figure 1.20. Bank exposure relative to the river elevation $(A)$, described section of the bank exposure $(B)$, thick root mat possibly obscuring some of the most recent stratigraphy $(C)$, and some of the unique deposits described in the stratigraphy $(D$ and $E)$, at the Williams Island site, Tennessee River, Tennessee.

The next deposit dated was a thin silty fine sand directly overlying the two extensively occupied deposits (fig. 1.21). The charcoal here was dated to $2872-2583$ B.C. The last deposit dated using radiocarbon analysis was the oldest extensively occupied layer. The date range of this deposit is 3519-3365 B.C., older than all floods at all sites in this study. Compared to the rest of the flood record along this reach of the Tennessee River, the section of Williams Island representing a similar record from those sites is most likely the upper onehalf $\mathrm{m}$ of sediment. We were not able to distinguish individual floods in this younger stratigraphy with such fine resolution here owing to bioturbation, permit restrictions, and limited site access. Therefore the Williams Island site was not explicitly included in the development of the paleoflood record for this report. 


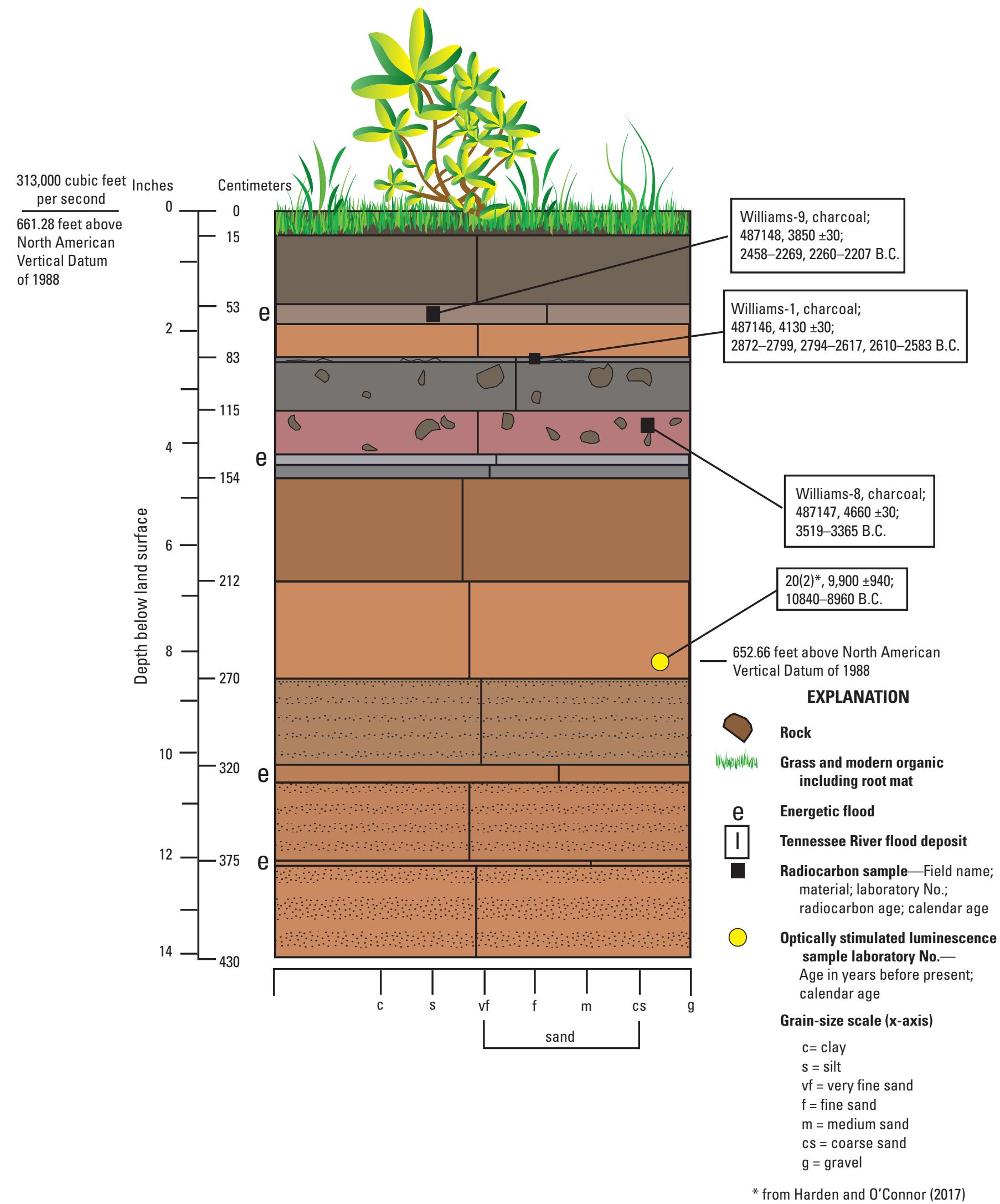

Figure 1.21. Stratigraphy at the William Island site, Tennessee River, Tennessee. 
Publishing support provided by the U.S. Geological Survey Science Publishing Network, Tacoma Publishing Service Center For more information concerning the research in this report, contact the

Director, Oregon Water Science Center

U.S. Geological Survey

2130 SW 5th Avenue

Portland, Oregon 97201

https://www.usgs.gov/centers/or-water 
